\title{
DOE/ET/28365-5
}

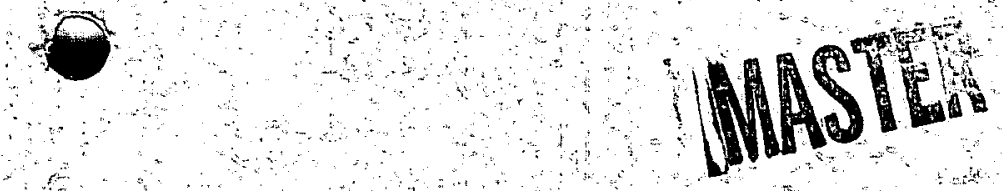

\section{Hydrogeologic and Geothermal Investigation of \\ Pagosa Springs, Colorado}

\author{
by Michael J. Galloway
}

1980

Work performed under Contract No. DE-ASO7-77-ET28365

COLORADO GEOLOGICAL SURVEY

DEPARTMENT OF NATURAL RESOURCES

DENVER, COLORADO

Prepared for

U.S. Department of Energy

Division of Geothermal Energy 


\section{DISCLAIMER}

This report was prepared as an account of work sponsored by an agency of the United States Government. Neither the United States Government nor any agency Thereof, nor any of their employees, makes any warranty, express or implied, or assumes any legal liability or responsibility for the accuracy, completeness, or usefulness of any information, apparatus, product, or process disclosed, or represents that its use would not infringe privately owned rights. Reference herein to any specific commercial product, process, or service by trade name, trademark, manufacturer, or otherwise does not necessarily constitute or imply its endorsement, recommendation, or favoring by the United States Government or any agency thereof. The views and opinions of authors expressed herein do not necessarily state or reflect those of the United States Government or any agency thereof. 


\section{DISCLAIMER}

Portions of this document may be illegible in electronic image products. Images are produced from the best available original document. 


\section{NOTICE}

This report was prepared to document work sponsored by the United States Government. Neither the United States nor its agent, the United States Department of Energy, nor any Federal employees, nor any of their contractors, subcontractors or their employees, makes any warranty, express or implied, or assumes any legal liability or responsibility for the accuracy, completeness, or usefulness of any information, apparatus, product or process disclosed, or represents that its use would not infringe privately owned rights.

\section{NOTICE}

Reference to a company or product name does not imply approval or recommendation of the product by the Colorado Geological Survey or the U.S. Department of Energy to the exclusion of others that may be suitable.

Cover photos: Drilling site and rig at Pagosa Springs. 
HYDROGEOLOGIC AND GEOTHERMAL INVESTIGATION

OF PAGOSA SPRINGS, COLORADO

by

Michael J. Galloway

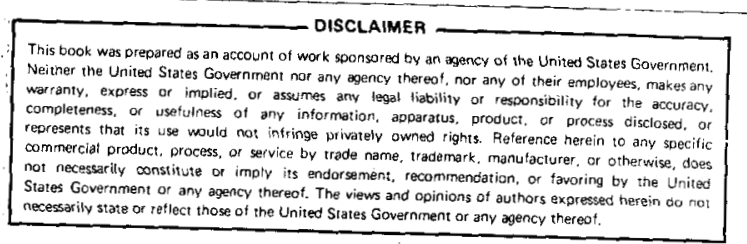

Prepared by the COLORADO GEOLOGICAL SURVEY

in cooperation with the

U.S. Department of Energy

Under Contract No. DE-ASO7-77-ET28365

COLORADO GEOLOGICAL SURVEY

DEPARTMENT OF NATURAL RESOURCES

STATE OF COLORADO

DENVER, COLORADO

1980

$\$ 10.00$

$Q 6$

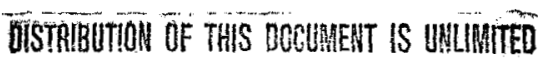




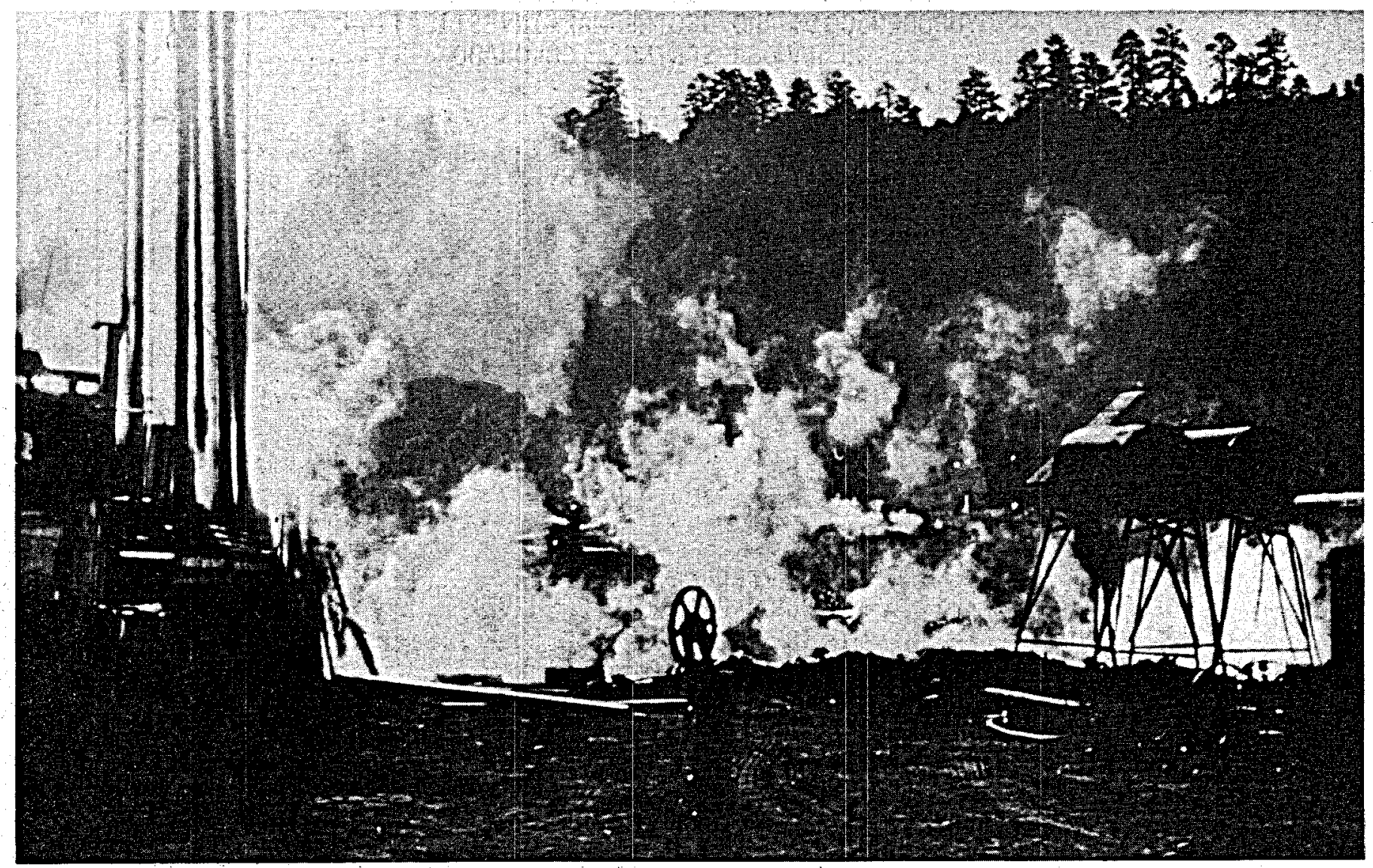

Drilling at Pagosa Springs. Photo by Michael Galloway 
INTRODUCTION .....................................

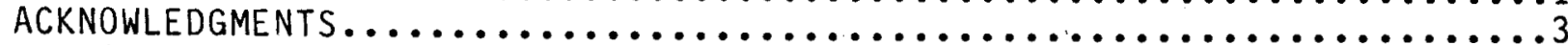

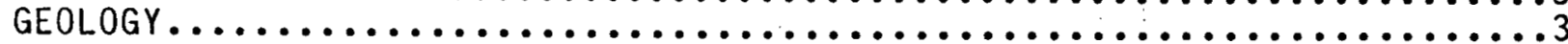

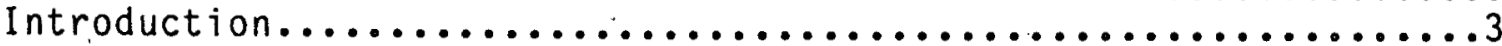

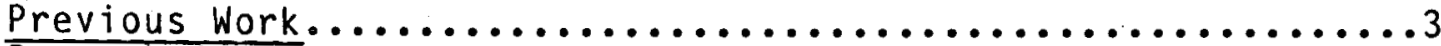

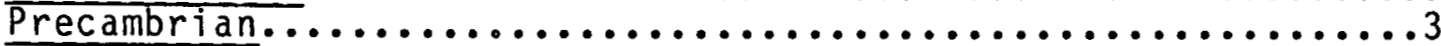
Upper Triassic and Jurassic $($ ? $) \ldots \ldots \ldots \ldots \ldots \ldots \ldots \ldots \ldots \ldots \ldots \ldots \ldots$

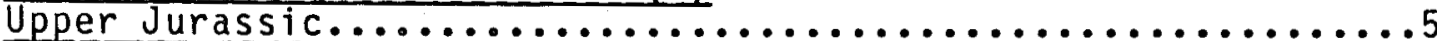

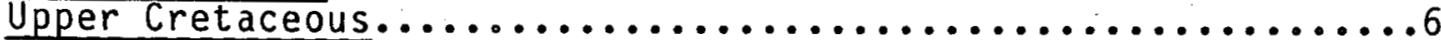

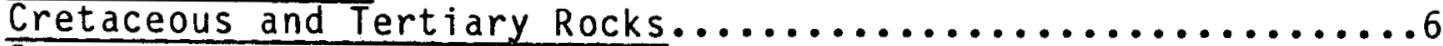
Quaternary Deposits..............................

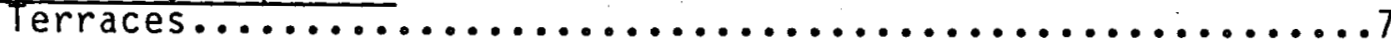

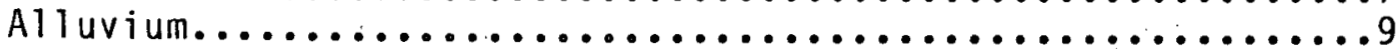

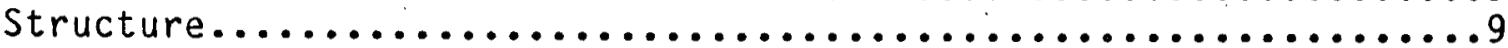

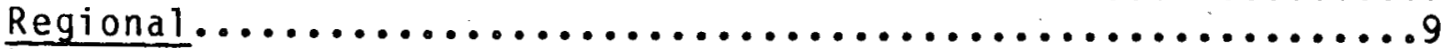

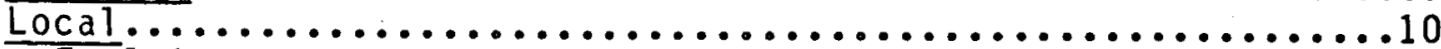

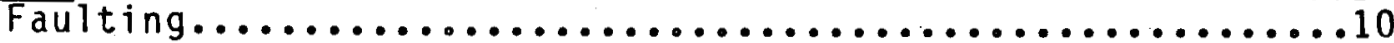

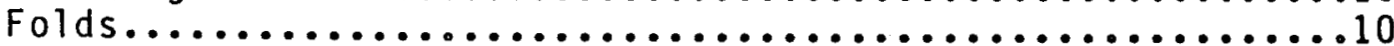

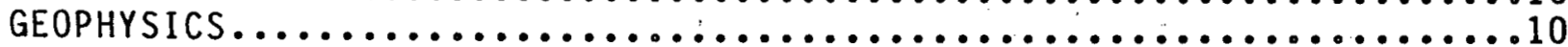

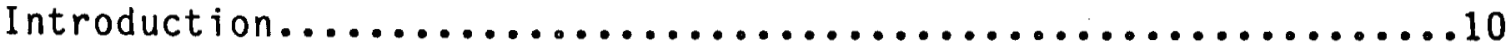

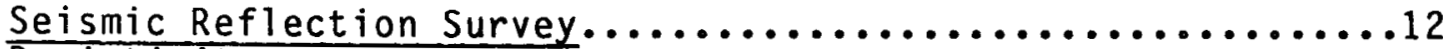

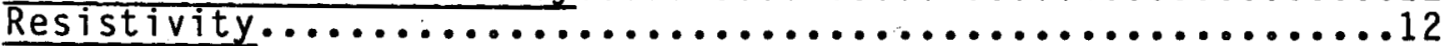

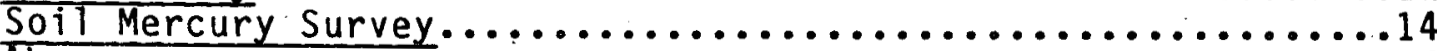

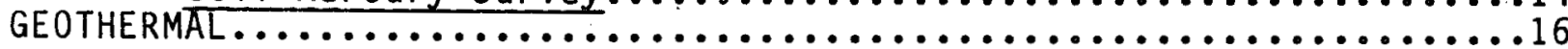

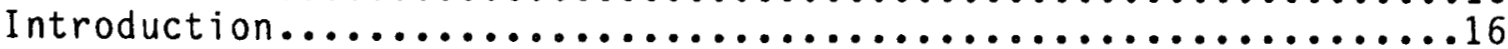

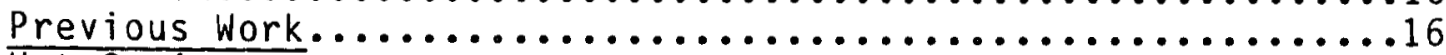

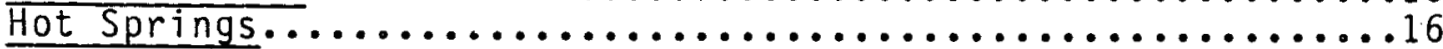

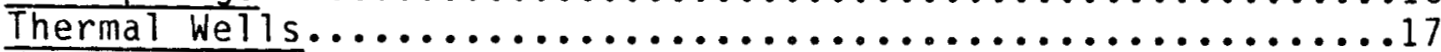

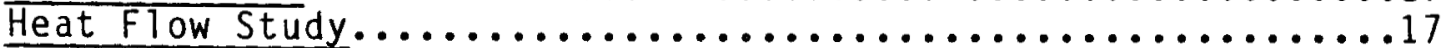

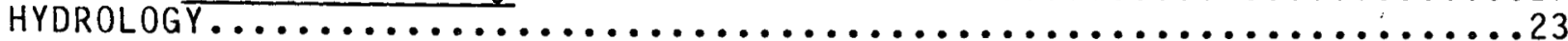

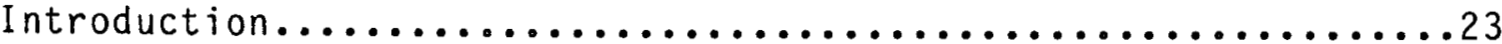

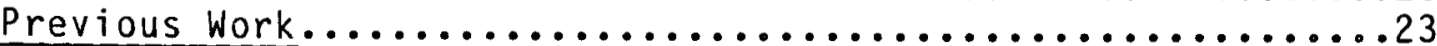

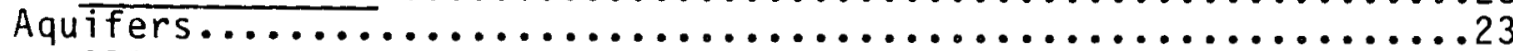

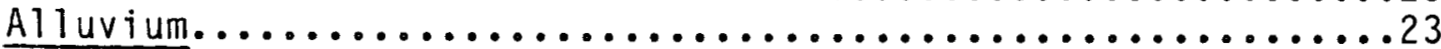

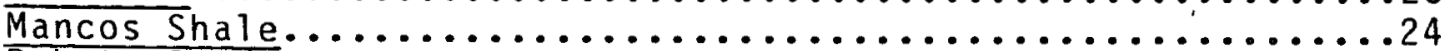

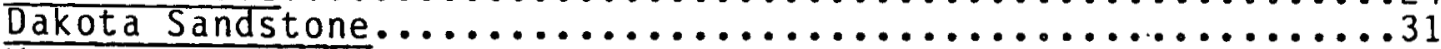

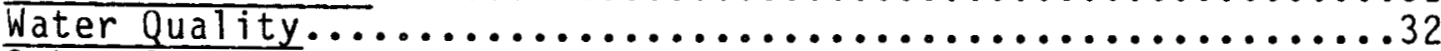

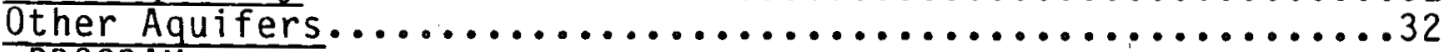

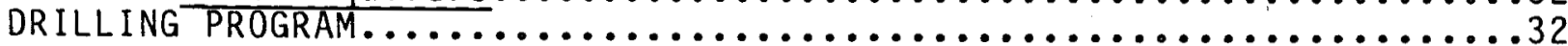

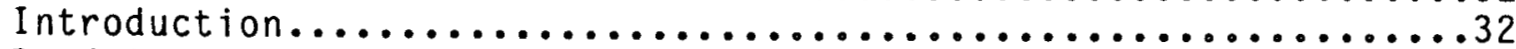

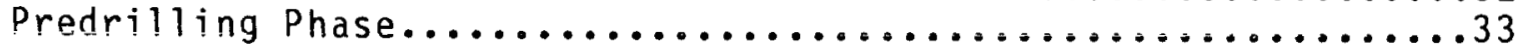

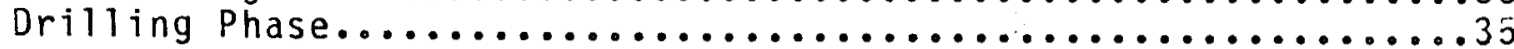

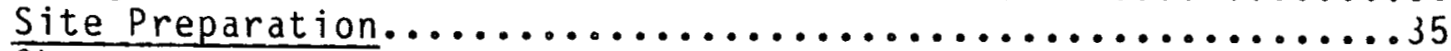

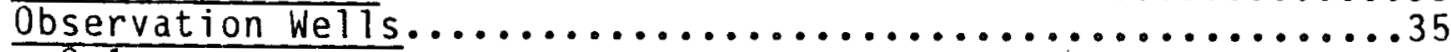

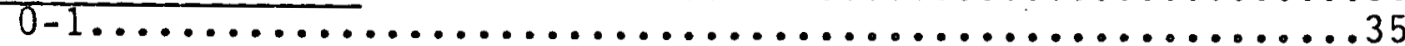

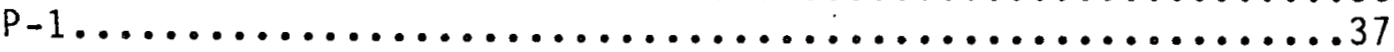

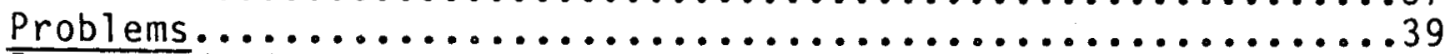

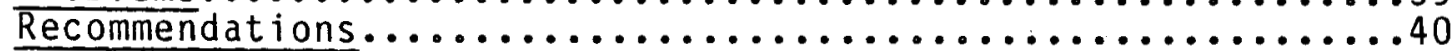

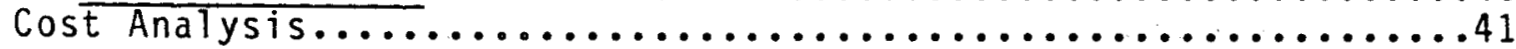

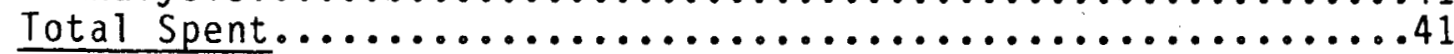

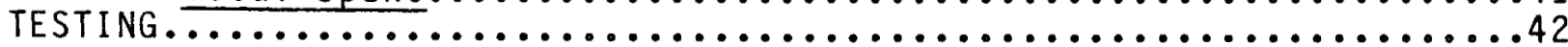

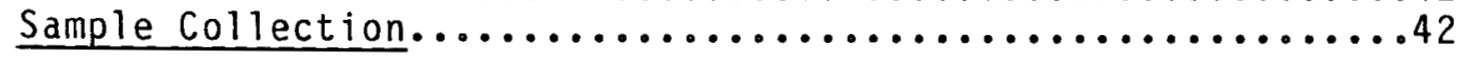


Insitu Testing................................

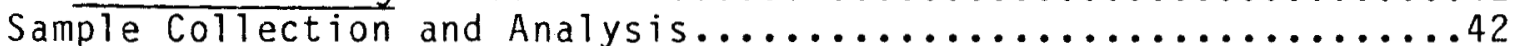

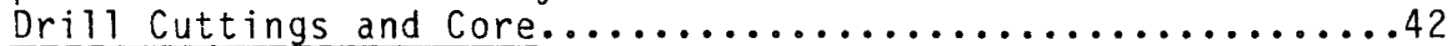

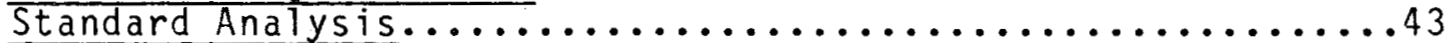

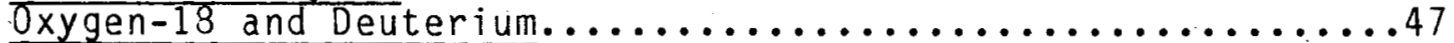

Tritium Anatyses................................

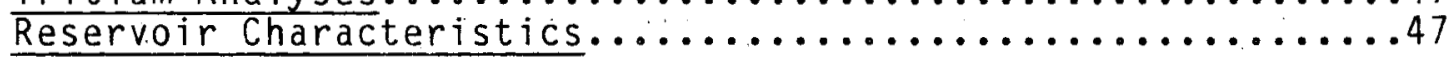

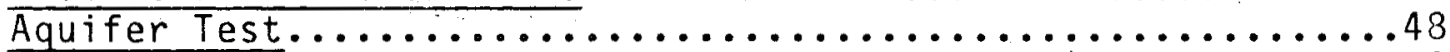

Temperature, $\mathrm{pH}$, Conductivity, and Discharge..............

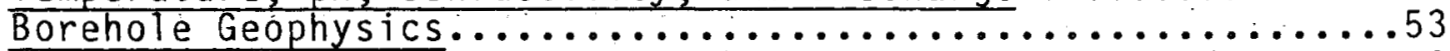

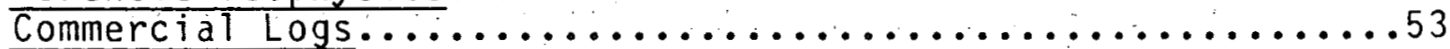

Well Pressure Changes During Drilling................62

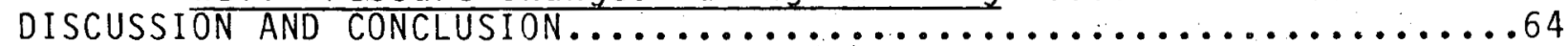

General Nature of the Pagosa Springs Geothermal System......64

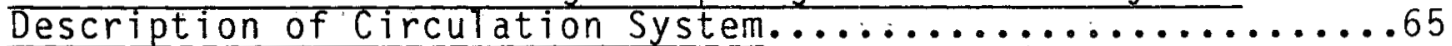

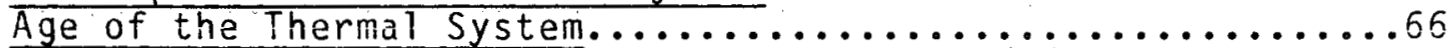

MINERALOGICAL AND PETROGRAPHIC INVESTIGATION OF SAMPLES FROM

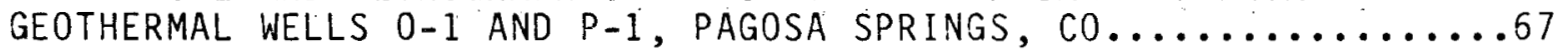

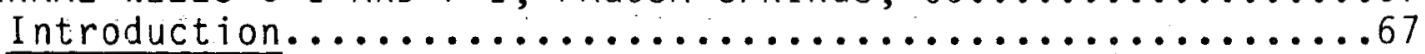

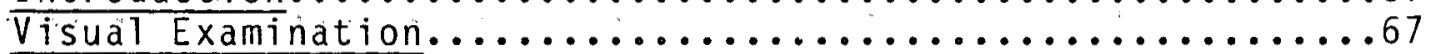

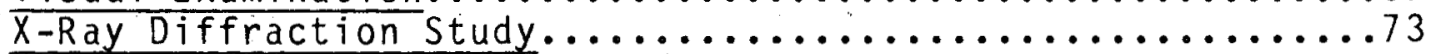

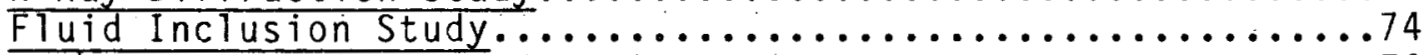

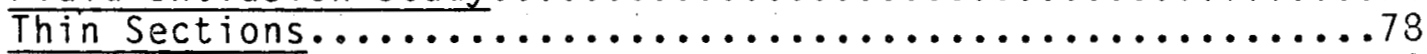

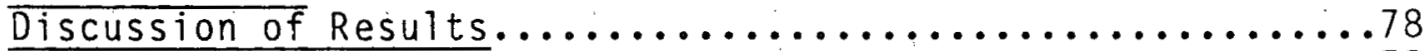

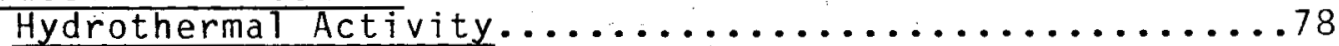

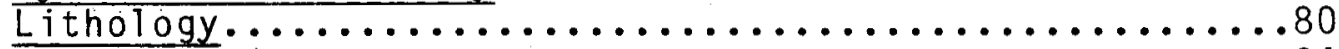

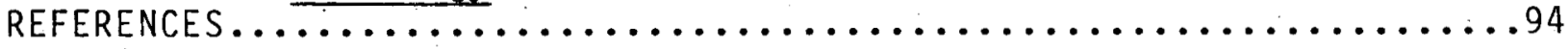


1. Wells which have encountered Precambrian rock, Archuleta

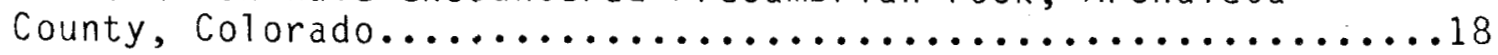

2. Inventory of thermal spring vents, Pagosa Springs, Colorado....18

3. Chemical analysis of Hot Spring Vent A, Pagosa Springs,

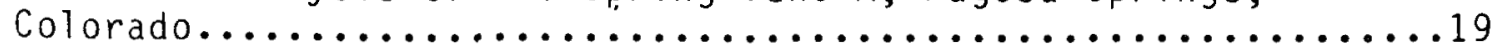

4. Thermal well inventory, Pagosa Springs, Colorado...........20

5. Chemical analyses of water from thermal wells, Pagosa springs,

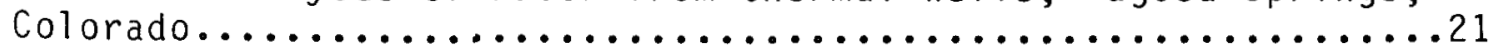

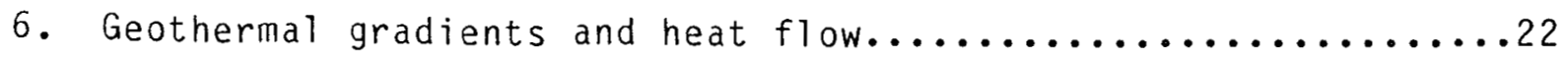

7. Well inventory, Pagosa Springs Area, Colorado.............26

8. Chemical analyses of thermal waters from the CGS test wells...46

9. Stable isotope ratio analyses......................47

10. Calculated value of transmissivity and storativity.........57

11. Summary table of physical parameters from $0-2 \ldots \ldots \ldots \ldots . \ldots . \ldots 59$

12. Summary table of physical parameters from $P-1 \ldots \ldots \ldots \ldots . . \ldots 59$

13. Visual description of well cuttings.................68

14. Visual $\log$ of diamond dril1 core from well P-1............72

15. Mineralogy of $0-1$ and $P-1$ well cutting determined by $x$-ray

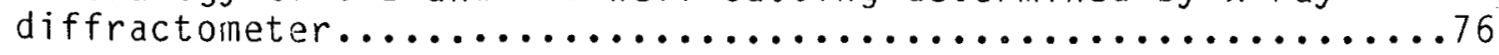

16. Thin section studies of sedimentary rocks......................

17. Thin section studies of Precambrian metamorphic and igneous

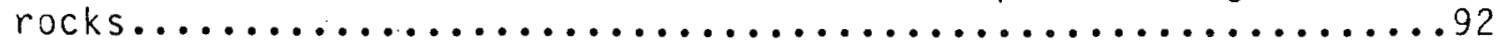




\section{FIGURES}

\section{PAGE}

1. Index map of the Pagosa Springs Study Area.................

2. Regional structure of the Pagosa Springs Area, Colorado........4

3. Stratigraphic Section from Test Wel1 P-1, Pagosa Springs, Colorado..........................................

4. Cross section through the Pagosa Springs Area...............11

5. Dipole-Bipole Resistivity, Pagosa Springs, Colorado...........13

6. Dipole-Dipole Resistivity, Pagosa Springs, Colorado..........15

7. Site plan of Test Well Area, Pagosa Springs, Colorado.........36

8. Well Completion Diagrams of Wells $0-2$ and $P-1 \ldots \ldots \ldots \ldots \ldots . \ldots 38$

9. Trilinear Diagram of Waters from the Pagosa Springs Area......44

10. Time-Drawdown curve (semi-log) of the Courthouse Well........49

11. Time-Drawdown curves $(\log -10 g)$ of Observation Wells.........51

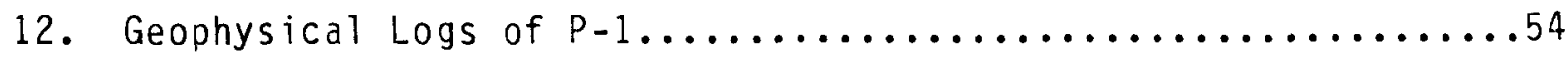

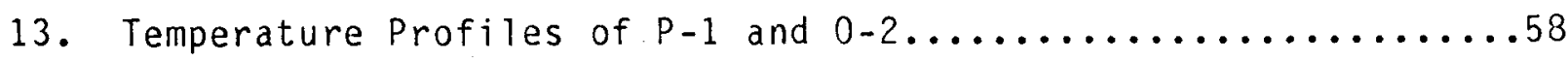

14. Hydrographs of Thermal Wells and Springs, Pagosa Springs,

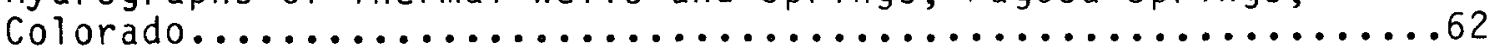

\section{PLATES}

1. Geologic map of the Pagosa Springs Area, Colorado.

2. Geothermal Map of Pagosa Springs, Colorado.

3. Hydrologic Map of the Pagosa Springs Area, Colorado.

Figure 1, Elevation of the Water Surface, Mancos Shale, Pagosa Springs Area, Colorado

Figure 2, Elevation of the Potentiometric Surface, Dakota Sandstone, Pagosa Springs Area, Colorado. 
The Colorado Geological Survey is involved in an ongoing investigation of various geothermal reservoirs within the State of colorado in order to assess the geothermal potential of the State. Funding for this investigation is supplied by the U.S. Department of Energy, Division of Geothermal Energy through the State Coupled Program, Contract Number AS07-77ET23365. This is the final report of one such study in Pagosa Springs, Colorado.

Pagosa Springs, Archuleta County, Colorado, is located $280 \mathrm{mi}(448 \mathrm{~km})$ southwest of Denver and $65 \mathrm{mi}(106 \mathrm{~km})$ east of Durango (Fig. 1) and has a population of about 1325 (Koulet and Armstrong, 1978). The area of investigation includes 211 $\mathrm{mi}^{2}\left(550 \mathrm{~km}^{2}\right)$, centered on the city of Pagosa Springs (Fig. 1). Pagosa Springs is located on the northeastern edge of the San Juan Basin approximately 15 , $\mathrm{mi}(24 \mathrm{~km})$ west of the continental divide, at an elevation of $7000 \mathrm{ft}(2121 \mathrm{~m})$. Precipitation, $65 \%$ of which falls as snow, ranges from $49 \mathrm{in.}(125 \mathrm{~cm})$ at higher elevations to $24 \mathrm{in} .(60 \mathrm{~cm})$ at the lower elevations. Vegetation is very dense in much of the higher elevations of the area, but thins significantly at lower elevations, particularly on soil developed from the various shales.

Pagosa Springs was selected for this study because of probable geothermal resource potential and community interest. Adequate subsurface temperature (Barrett and Pearl, 1978) and measured surface flows justified further reservoir investigation. Initially, a reservoir assessment and confirmation study was to be used by the local school district for a:planned new high school. During the early phases of this program, a school bond issue was defeated. However, community interest remained high for the use of the geothermal water and it was decided to continue the investigation.

A Program Opportunity Notice (PON) was submitted by Pagosa Springs in July, 1978 with the aid of two Denver consulting firms and has since been accepted by DOE. The PON proposes to estabijsh a district heating system utilizing the test wells drilled by the Colorado Geological Survey (CGS) and existing hot water wells. 


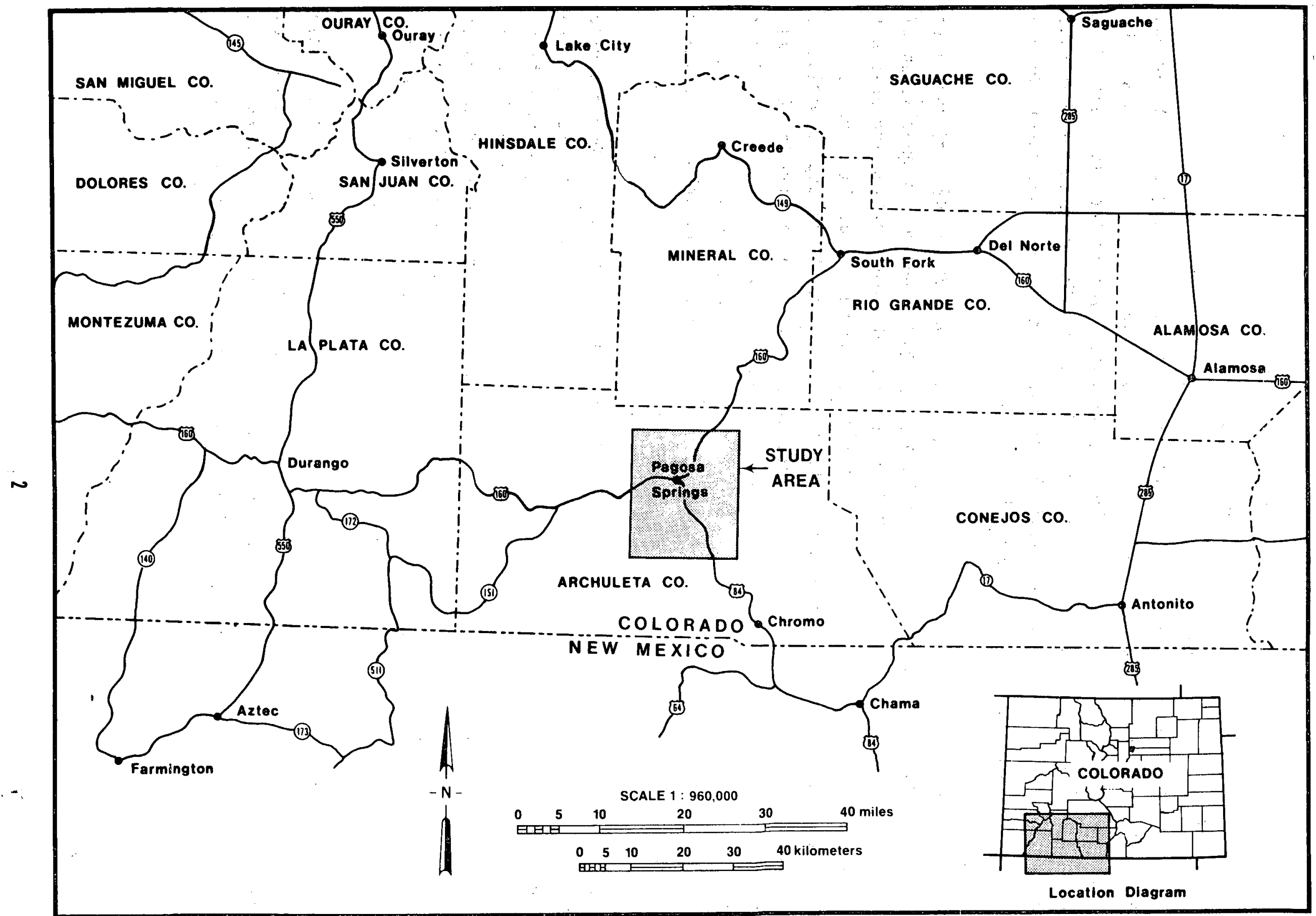

Figure 1 - Index Map of the Pagosa Springs Study Area 


\section{ACKNOWLEDGMENTS}

Maps and illustrations were drafted by Mark V. Persichetti. The manuscript was typed by Becky Andrews.

GEOLOGY

Introduction

Pagosa Springs is located on the Archuleta anticlinorium (Ryder, 1977a) which divides the San Juan basin to the southwest from the Chama basin to the east and the San Juan sag to the northeast (Fig. 2): A $12,000 \mathrm{ft}(3700 \mathrm{~m})$ section of Upper Triassic through Tertiary sedimentary and volanic rocks unconformably rests on Precambrian basement rocks. Several normal fault trends and Tertiary dikes occur in the mapped area.

Previous Work

The Pagosa Springs 7 1/2' Quadrangle was mapped by Hail (1965) in considerable detail. The 15' quadrangles to the southwest, southeast, and northeast were mapped in various degrees of detail by Dunn (1964) and Wood and others (1948). Studies of regional interest include Ryder (1977a and b), Read and others (1949), and Steven (1974). Except for the Pagosa Springs Quadrangle, these maps have been modified by air-photo interpretation and field mapping during this study.

\section{Stratigraphy}

Precambrian

Rocks of Precambrian age have been encountered in several wells in southern Archuleta County (Wood and others, 1948; Ryder, 1977a \& b; and Barrett and Pearl, 1976) (Table 1). Restored stratigraphic sections by Ryder (1977a) show the occurrence of Precambrian igneous and metamorphic rocks at shallow depths beneath all of southeastern Archuleta County. 


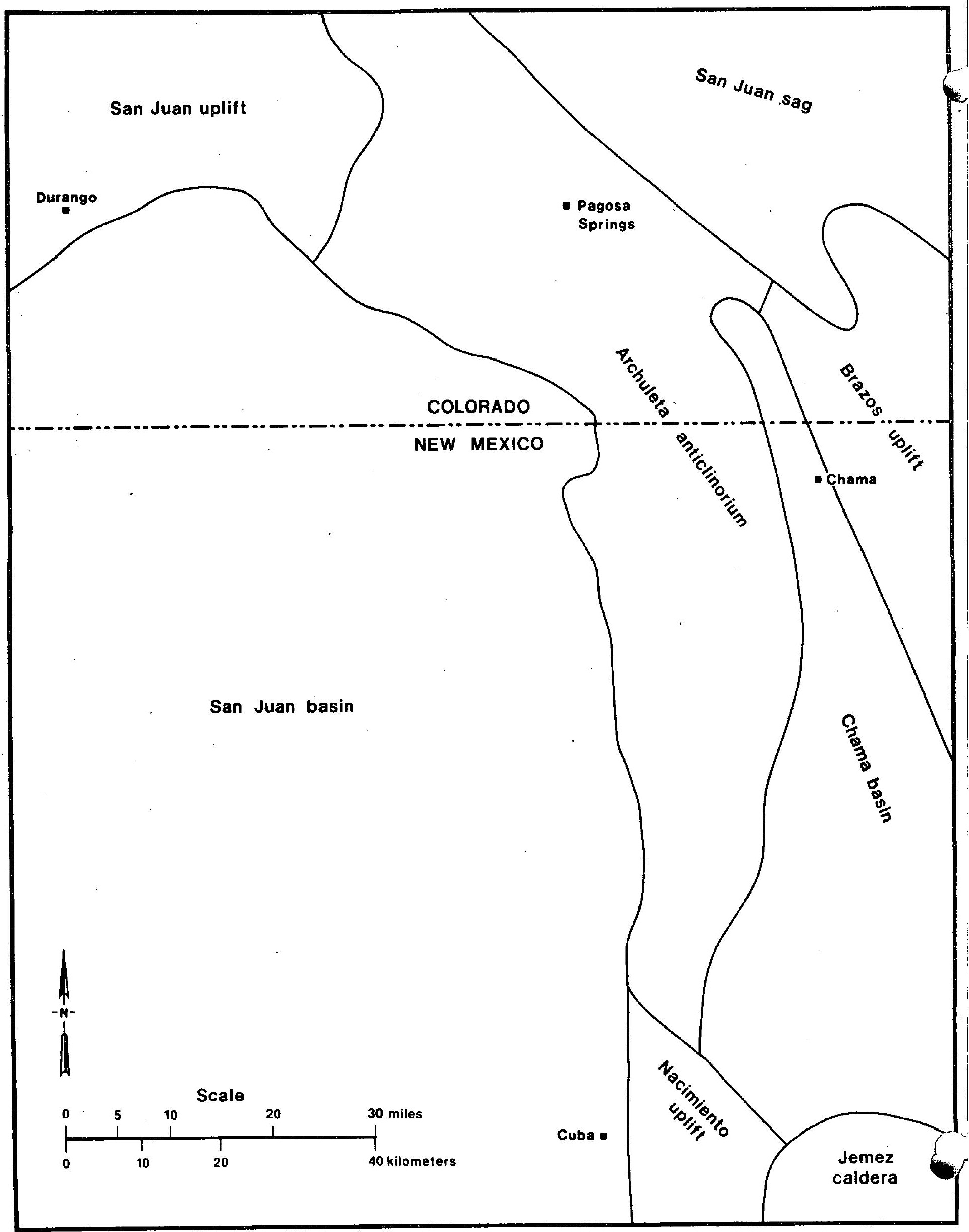

Figure 2 - Regional Structure of the Pagosa Springs Area, Colorado 
In the Piedra Canyon, $20 \mathrm{mi}(32 \mathrm{~km})$ west of Pagosa Springs, the Dolores Formation is $335 \mathrm{ft}(10.2 \mathrm{~m})$ thick and is comprised of red; brownish-red, gray, and purple shale, sandstone, and conglomerate (Wood and others, (1948) and unconformably overlies the Precambrian basement. On the Sunetha anticline, $3 \mathrm{mi}(5 \mathrm{~km})$ southwest of Pagosa Springs, $37 \mathrm{ft}(11 \mathrm{~m})$ of the Dolores Formation were encountered in a Wildcat oil well. The Dolores Formation was not seen in the CGS test holes or in outcrops in the map area.

\section{Upper Jurassic}

The Entrada Formation unconformably overlies the Dolores Formation and Precambrian igneous and metamorphic rocks in the Pagosa Area. Two hundred and thirty ft (70 m) of buff-, gray-, or white-mottled, massively crossbedded and cliff-forming sandstone is exposed in Piedra Canyon (Wood and others, 1948). The Entrada Sandstone is $117 \mathrm{ft}(36 \mathrm{~m})$ thick on the Sunetha anticline and $90 \mathrm{ft}(27 \mathrm{~m})$ in the CGS test well. "Sand grains are commonly round or subround, frosted, fine to coarse, and cemented by calcium carbonate, iron carbonate, and clay." (Wood and others, 1948) (See Table 13).

The Wanakah Formation conformably overlies the Entrada Formation. Along the Piedra River, the Pony Express Limestone member consists of $26 \mathrm{ft}(8 \mathrm{~m})$ of thin or papery-laminated, crinkled, fetid limestone and thin sandstone beds (Wood and others, 1948). One hundred and seven $\mathrm{ft}(33 \mathrm{~m})$ of limestone and gypsum were logged on the Sunetha anticline and $96 \mathrm{ft}(29 \mathrm{~m})$ in the CGS test well. Along the Piedra River, the light-red sandstone and shale member consists of $70 \mathrm{ft}(21 \mathrm{~m})$ of red and pink sandstone, siltstone, and shale (Wood and others, 1948). This compares to $80 \mathrm{ft}(21 \mathrm{~m})$ in the Sunetha anticline and $50 \mathrm{ft}(15 \mathrm{~m})$ in the CGS test well.

The Morrison Formation, which is divided into two members, conformably overlies the Wanakah Formation. The white sandstone member, or "Upper La Plata" member, a massive white or light-gray sandstone, varies in thickness from $110 \mathrm{ft}(33 \mathrm{~m})$ along the Piedra River, to $218 \mathrm{ft}(66 \mathrm{~m})$ on the Sunetha anticline, and $56 \mathrm{ft}$ (17 
$m$ ) in the CGS test well. The overlying. variegated sandstorie and shale member is $334 \mathrm{ft}(101 \mathrm{~m})$ thick along the Piedra River, $420 \mathrm{ft}(127 \mathrm{~m})$ thick on the Sunetha anticline, and $519 \mathrm{ft}(157 \mathrm{~m})$ thick in the CGS test well. This member consists of gray, olive, brown, red-brown, and variegated shale interbedded with sandstone.

\section{Upper Cretaceous}

The Morrison Formation is disconformably overlain by the 117-270 $\mathrm{ft}(55-83 \mathrm{~m})$ thick Dakota Sandstone (Wood and others, 1948). The lower member is buff, cross-bedded, massive, medium- to coarse-grained, and conglomeratic and is overlain by a dark-gray to buff, carbonaceous, silty middle shale member. The upper member is a buff, cross-bedded, massive, medium- to fine-grained sandstone (Wood and others, 1948) (see Table 13).

Although the Mancos Shale, which overlies the Dakota Sandstone, can be subdivided into numerous members, for mapping purposes the Mancos is undivided in this report. Hail (1965) (Plate 1), divides the Mancos into upper and lower parts, based on the amount of calcareous material versus shale. The Mancos Shale varies in thickness from $2100 \mathrm{ft}(636 \mathrm{~m})$ to $2370 \mathrm{ft}(718 \mathrm{~m})$ and is predominantly dark-gray to black, carbonaceous, moderately massive to fissile shales, interbedded with thin discontinuous sandstones and blocky, fossiliferous limestones.

Overlying and intertonguing with the Mancos Shale is the Mesa Verde Formation, which is composed of buff to gray, cliff-forming sandstones and interbedded gray shales. On the Piedra River, the Mesa Verde Formation is $365 \mathrm{ft}$ (111 m) thick. Northeast of Pagosa Springs, the Mesa Verde Formation changes laterally into shales and thin sandstone beds and it is difficult to differentiate from overlying and underlying shales (Wood and others, 1948).

The Lewis Shale, consisting of $2400 \mathrm{ft}(727 \mathrm{~m})$ of dark- to light-gray shale, overlies and intertongues with the Mesa Verde Formation.

\section{Cretaceous and Tertiary Rocks}

The Animas Formation consists of gray, buff, brown, olive, and purple, fine- to 
coarse-grained sandstone, conglomerate, shale and siltstone 400-500 ft (120-150 m) thick. Pebbles and cobbles of Paleozoic and Precambrian rocks and angular to sub-rounded fragments of volcanic glass, andesite, and latite are common (Wood and others, 1948).

Blanco Basin rocks, up to $400 \mathrm{ft}(121 \mathrm{~m})$ thick, are similar to those of the Animas Formation; consisting of feldspathic sandstone and pebble conglomerate and silty shale. However, unlike the Animas Formation, metamorphic and plutonic rock fragments are abundant, and volcanic detritus is lacking (Dunn, 1964).

The Conejos Quartz Latite is the basal formation of the Potosi volcanic field (Dunn, 1964). This unit represents up to $5050 \mathrm{ft}(1515 \mathrm{~m})$ of erruptive volcanic and volcano-clastic rocks which comprise the majority of large rock exposures on the west side of the San Juan Mountains. Volumetrically, the Conejos Quartz Latite is the largest of the San Juan Mountains volcanic units (Dunn, 1964 ).

Numerous concordant plutons, including granodiorite, diorite, and syenites, found in the area are tentatively dated as Conejos (Dunn, 1964). North of Pagosa Springs, Cretaceous intrusives have been encountered in drill holes; for example, the oil exploration hole BMG 1 Quartz Creek (T.36N., R.2E., Sec. 5) (Ryder, 1977 ). These intrusives may be part of a subvolcanic batholith postulated by Lipman and others (1978) that lies beneath the San Juan volcanic field.

Lamprophyre and diabasic intrusives of Latest Miocene age occur throughout the area. Dikes up to $12 \mathrm{ft}(3 \mathrm{~m})$ wide and $8.5 \mathrm{mi}(14 \mathrm{~km})$ 1ong, trend north-northeast and constitute the Archuleta dike swarm (Dunn, 1964). Bake zones up to $5 \mathrm{ft}$ ( 1.5 m) wide are particularly prominent in the Mancos and Lewis shales. Evidence of hydrothermal alteration associated with the dikes is not seen (Dunn, 1964 ).

\section{Quaternary Deposits}

Terraces

Quaternary gravels occur on several surfaces in the area but are not subdivided in this report. These surfaces were described by wood and others (1948) as pediments 


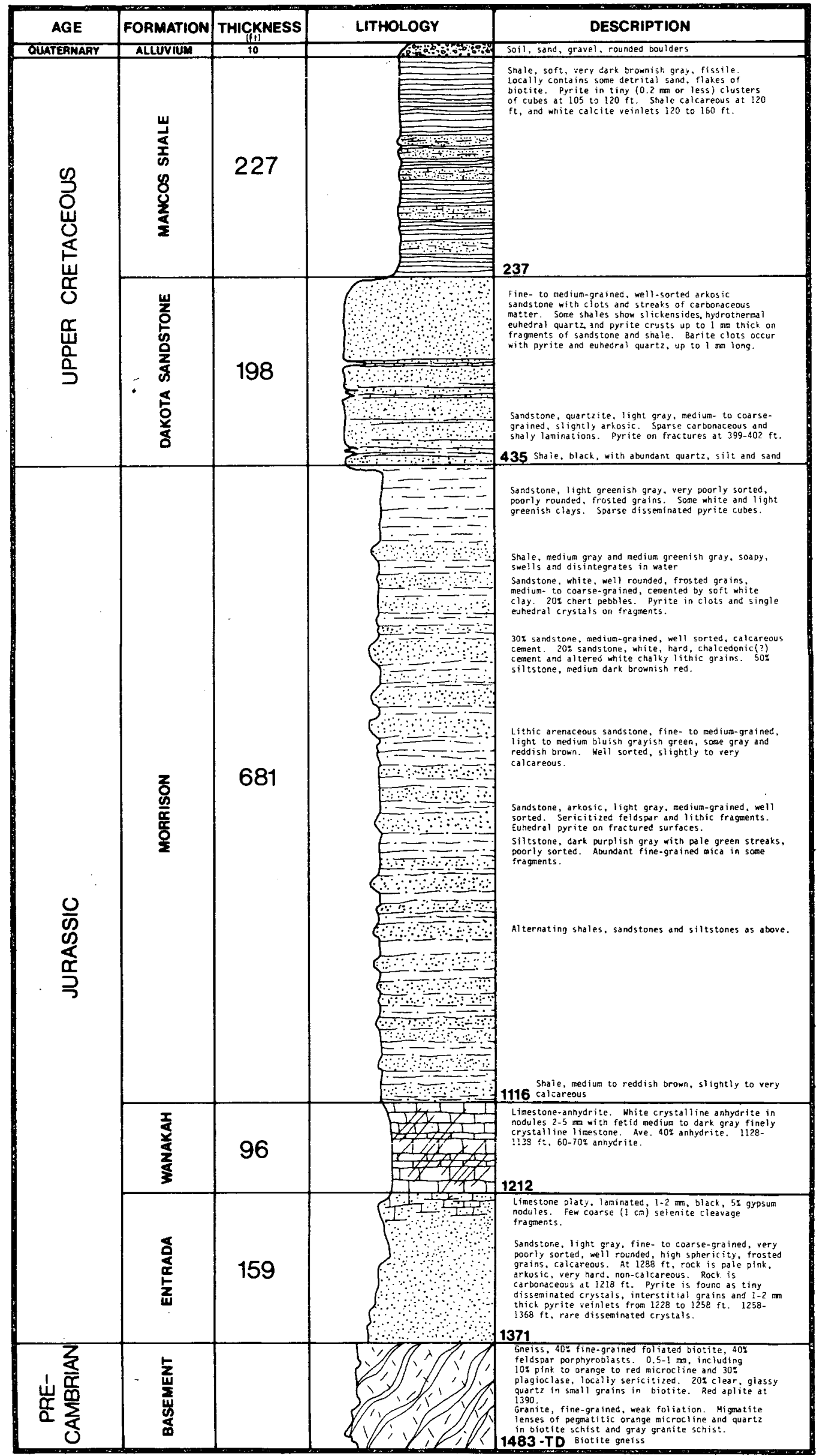

Figure 3 - Stratigraphic Section from Test Well P-1, Pagosa Springs, Colorado 
but have been subsequently referred to as terraces by Dunn (1964). This author agrees with the latter interpretation because these features do not have the geomorphic characteristics of a pediment.

Al ruvium

All alluvial deposits along the major river valleys and many tributaries and deep surficial material on broad upland areas are mapped as recent alluvium (Plate 1).

See Dunn (1964) for detailed lithologic and stratigraphic descriptions of preceeding formations.

Structure

Regional

The name Archuleta anticlinorium was first applied to the structural divide between the San Juan and Chama basins, the major structures of this region, by Wood and others (1948)(Fig. 2). The term has since been used by Dunn (1964) and Ryder (1977 a and b). "The Archuleta anticlinorium is characterized by 1) westto northwest-trending, upright and inclined, plunging, cylindrical folds, 2) northwest-trending, longitudinal faults, and 3 ) northeast-trending transverse faults." (Ryder, 1977b). The anticlinorium is $75 \mathrm{mi}(121 \mathrm{~m})$ long and 6 to $16 \mathrm{mi}$ (10 to $26 \mathrm{~km}$ ) wide (Kelly and Clinton, 1960). This complex zone of faults and folding is the northward continuation of the basement cored Nacimiento and San Pedro Mountains of New Mexico (Wood and others, 1948 and Ryder, 1977b) (Fig. 2).

Except for minor structural growth during Paleozoic time, Ryder (1977b) attributes most of these structures to Laramide activity, which was strongly influenced by differential movement of faulted Precambrian basement. Many of these structures were probably rejuvenated during Middle to Late Tertiary uplifting and tilting (Ryder, 1977b). 
$\underline{\text { Local }}$

Faulting

The dominant fault trend in the Pagosa area is $N 40^{\circ} \mathrm{N}$ and vertical. Minor faulting occurs in east-west and north-south directions. Dip-separations range from a high of $300 \mathrm{ft}(100 \mathrm{~m})$ to less than $10 \mathrm{ft}(3 \mathrm{~m})$, which are relatively small compared to the lengths of these faults (Plate 1). The major fault in the Pagosa Springs area is a northwest-trending normal fault with $300 \mathrm{ft}(100 \mathrm{~m})$ of vertical displacement (Plate 1 and Fig. 4). The fault trace is relatively unaffected by topography, suggesting the fault is nearly vertical. This fault is here named the Eight Mile Mesa fault, after the prominent mesa which is transected by this fault (Plate 1).

Dunn (1964) attributes the faulting to flexing of brittle beds over the crest of the Archuleta anticlinorium which is thought to have grown after the deposition of the Eocene(?) Blanco Basin Formation. This implies that faulting occurred during Late Eocene time. Many of the faults displace dikes of Late Miocene age and other faults cross-cut, but do not displace dikes, making some of the faulting of Late Miocene age.

Folds

The Sunetha and Stinking Springs anticlines, trending $N 40^{\circ} \mathrm{W}$, are the only named folds in the mapped areas. "Two other anticlines, trending $N 60^{\circ} \mathrm{W}$, occur near Pordonia Point and Oak Brush Hill in the southwest corner of the map area (Plate 1). A third anticline, trending $N 45^{\circ} \mathrm{W}$, occurs on the eastern edge of the map. Relief on the bottom of the Dakota Sandstone is $525 \mathrm{ft}(160 \mathrm{~m})$ for the Sunetha anticline and $225 \mathrm{ft}(70 \mathrm{~m})$ for the Stinking Springs anticline (Fig. 4$)$.

\author{
GEOPHYSICS
}

\title{
Introduction
}

Several geophysical surveys were run in the Pagosa Springs area during the 


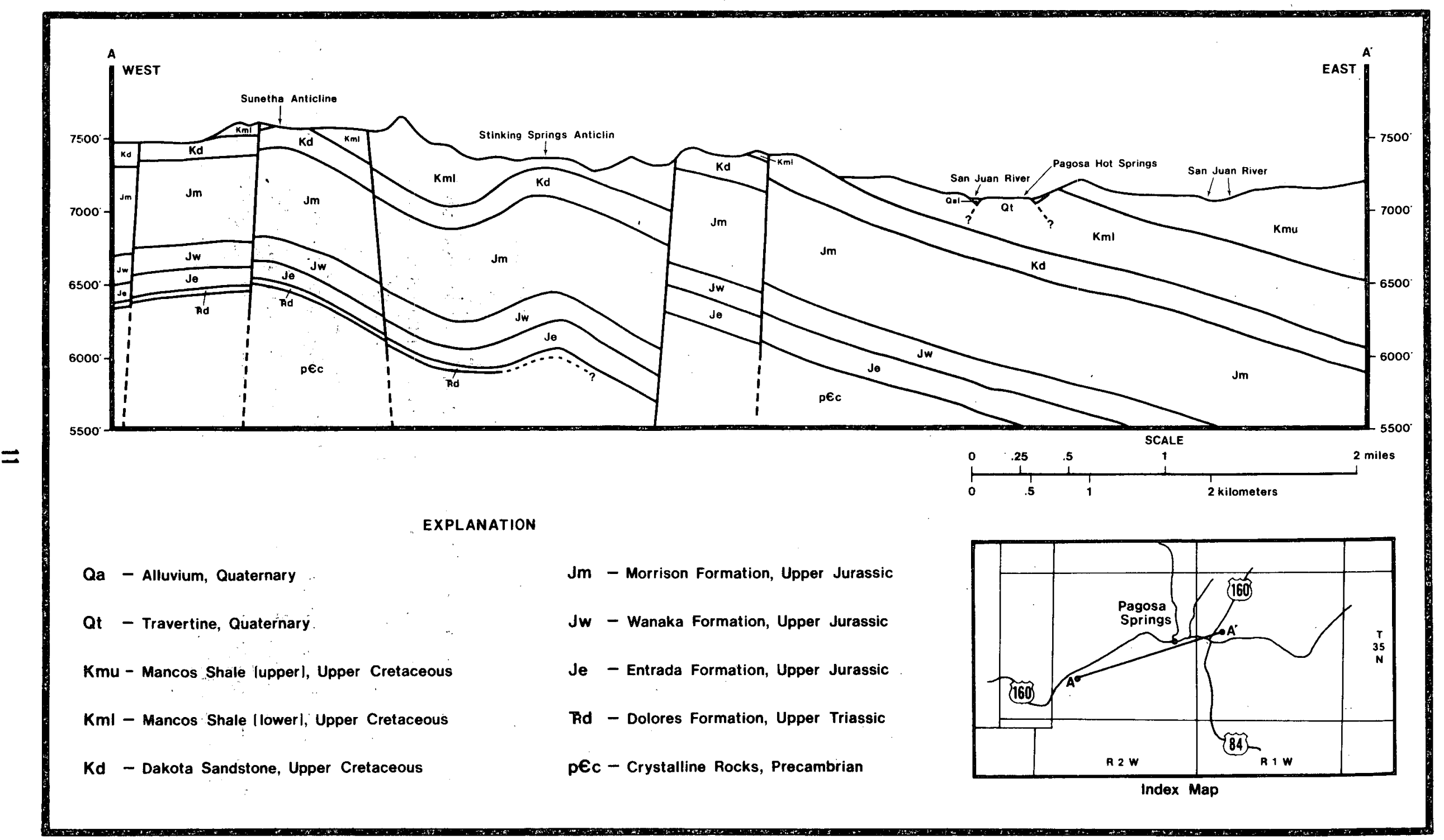

Figure 4 - Cross Section through the Pagosa Springs Area, Colorado 
summer of 1977 by Geophysics Fund. Inc. (GFI) of the Colorado School of Mines for the CGS. These included two resistivity surveys, a seismic reflection survey, and a soil mercury survey. Unfortunately, none of these methods successfully defined subsurface conditions. However, the dipole and bipole surveys did delineate the same near-surface anomaly as, the hot water well data.

Seismic Reflection Survey

Using a vibrator source, GFI ran three lines through the Pagosa area (Fig. 5 ). Utilizing a stratigraphic section from the Gramps 0 il Field, located $20 \mathrm{mi}$ (32 km) southeast of Pagosa Springs, three marker horizons were picked: Precambrian top $4000 \mathrm{ft}(1212 \mathrm{~m})$, Dakota Sandstone top $1600 \mathrm{ft}(485 \mathrm{~m})$, and the Mancos - Mesa Verde marker 400-500 ft (121-152 m). Later field work, additional data from oil and water wells, and confirmation by the geothermal test hole indicate the Dakota marker to be at approximately 400-500 ft and the Precambrian at 1400-1500 ft.

A major east-west-trending fault postulated by GFI to be just north of the hot spring cannot be substantiated. The only north-south vibroseis line was shifted about one-quarter mile $(.4 \mathrm{~km})(F i g .5)$ along nearly the same east-west line as the postulated fault. Also, subsurface data from water wells do not indicate any displacements over $25 \mathrm{ft}(8 \mathrm{~m})$ of the sedimentary units across the Pagosa area.

\section{Resistivity}

Dipole-Bipole Survey (depth of penetration up to $1000 \mathrm{~m}$ )

This survey covered approximately $12 \mathrm{mi}^{2}\left(32 \mathrm{~km}^{2}\right)$ centered on Pagosa Springs. The bipole source was located $1.5 \mathrm{mi}(2.4 \mathrm{~km})$ south-southeast of the town along U.S. Highway 84 and was $2500 \mathrm{ft}(750 \mathrm{~m})$. long (Fig. 5 ).

Background resistivities range from 150-400 ohm-meters in the Pagosa Springs area (Fig. 5). Any area within the 100 ohm-meter contours should be considered anomalous and probably represent thermal reservoirs at depth (Keller, 1977). The significance of some of these anomalous areas, however, can be discounted because of the following observations. The anomaly northeast of Pagosa Springs along the 


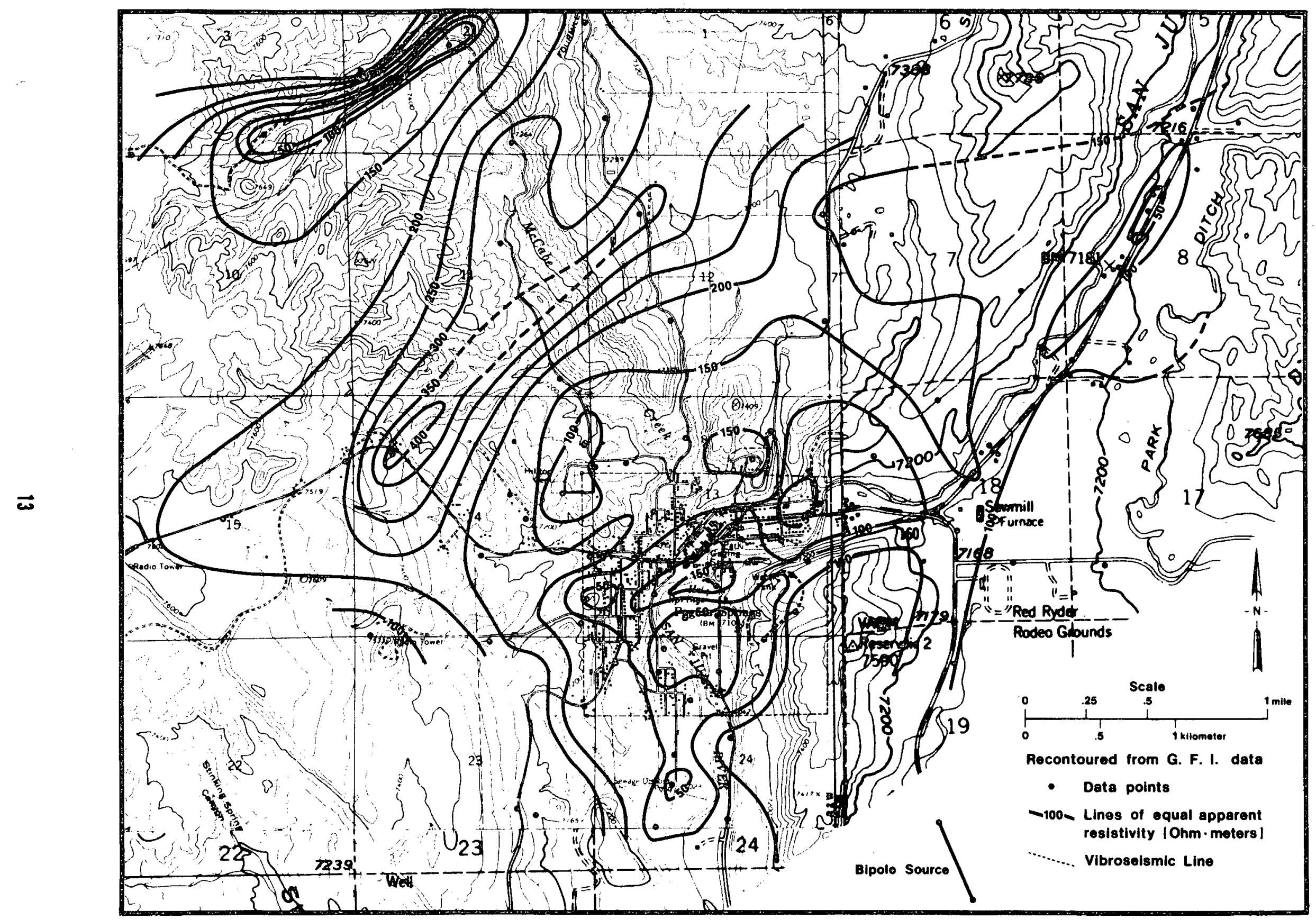

Figure 5-Dipole-Bipole Resistivity, Pagosa Springs, Colorado 
San Juan River is defined by a single low reading. Also, heat flow from two CGS well s within $1 \mathrm{mi}(1.6 \mathrm{~km})$ were the lowest in the area, 2.15 and $3.05 \mathrm{H} . \mathrm{F} . \mathrm{U}$. (Plate 2). The large anomaly $2.5 \mathrm{mi}(4 \mathrm{~km})$ northwest of Pagosa Springs is located along a buried gas pipeline and, therefore, suspect. The anomalies just northeast and northwest of the major spring anomaly cannot be explained as easily (Fig. 5). It is not known whether they represent hot water at depth or are due to some lithologic or cultural effects, but shallow wells drilled in these areas did not encounter hot water. "The main anomaly is centered over the spring area (Fig. 5). The lowest resistivity values here are just south of the spring vent, suggesting eittier down-gradient discharge to the south or the main reservoir is south of the spring vent.

The shape of the southward extension of this anomaly does suggest down-gradient discharge: The resistivity high which partially divides the major anomaly into two sections has not been explained. These readings could be in error because of the difficulty in making good ground contact on the travertine mound, or it could represent an influx of cold water into and mixing with the thermal water. More points around the spring may have been useful.

Dipole-Dipole Survey - (depth of penetration up to $60 \mathrm{~m}$ )

The low resistivity values from this survey appear to center around the known hot springs (Fig. 6). This implies (1) the conduit is restricted to a well defined area beneath the spring, or (2) the deep survey failed to penetrate beneath the highly conductive hot water zone and therefore the dipole-bipole contour pattern is actually describing the near-surface conditions.

\section{Soil Mercury Survey}

The soil mercury survey failed to delineate any anomalous areas and will not be discussed here. 
Introduction

The citizens of Pagosa Springs have used thermal water since the late 1800 's. As many as 30 wells have been drilled to provide thermal water in heating systems and recreation. However, due to corrision problems and plentiful and inexpensive natural gas, many of the wells were abandoned. Now, increases in energy costs have made geothermal energy more appealing. As an indirect outcome of the CGS study, Pagosa Springs has been awarded a grant to use the thermal water in a district heating system.

In addition to the geothermal test well, a heat flow study and a survey of existing springs and hot wells were carried out. These studies will be discussed in this section.

\section{Previous work}

Except for brief geochemical and geothermometry studies, such as Barrett and Pearl (1977) and White and others (1976), very little published work has been done on the thermal system at Pagosa Springs.

\section{Hot Springs}

The main thermal spring, "A", is located near the top of a fairly large travertine mound on the east side of the San Juan River (Plate 1). The mound covers an area of approximately $0.03 \mathrm{mi}^{2}\left(0.07 \mathrm{~km}^{2}\right)$ mostly on one side of the river. A few large travertine blocks can be found on the other side of the river, but it is not known if they are in place. Elevation of the mound ranges from $7055 \mathrm{ft}$ (2151 $\mathrm{m}$ ) at the river to $7077 \mathrm{ft}(2158 \mathrm{~m})$ near the actual pool. The main spring or pool. is about 25-35 ft $(8-10 \mathrm{~m})$ in diameter and of unknown depth. It has been reported that the spring has been probed to $100 \mathrm{ft}(38 \mathrm{~m})$ (Crouse, 1977, oral comm.) and $850 \mathrm{ft}(260 \mathrm{~m})$ (Vail, 1896) without finding the bottom. The validity of the last probe is uncertain. At one time the spring may have discharged a large quantity of water over the surface of the mound (Vail, 1896), but since wells have been 
drilled in the area, the water level appears to have dropped. Presently, the spring discharges through fractures and caverns below the surface and apparently feeds springs located at the periphery of the mound (Plate 2). Numerous outlets leading into the mound can be seen around the edge of the natural pool. Temperatures, discharge data, and chemical analyses are listed in Tables 2 and 3 .

\section{Thermal Wells}

There are 27 known hot wells that have been drilled since the early 1900 's in Pagosa Springs (Table 4), and only about half of these are in operation today. All of the wells presently in use, and presumably those which have been abandoned, are artesian. Piezometric pressures have been measured on only two of these wells (Table 4) because of poor well head conditions. The corrosiveness of the water made work on most well heads risky.

The areal extent of hot wells is limited to $0.04 \mathrm{mi}^{2}\left(0.1 \mathrm{~km}^{2}\right)$ (Plate 2). On the fringes of this area, warm water was encountered in wells 13DBAC (18), 13CBDC (17), and 13DCCC (25) (P1ate 2). Outside this fringe area, only cold water was encountered (Plate 2).

Complete chemical analyses are available for only two wells, 13 CADC1 and 13 DBCD1 (Table 5). There seems to be no significant difference between the water of these wells and the spring water.

\section{Heat Flow Study}

Six $300 \mathrm{ft}(100 \mathrm{~m})$ deep holes were drilled by G.F.I. around the Pagosa Springs area to aid in interpretation of the geophysical data and in selection of a test drilling site. These holes were located at about the same elevation and purposely kept from flowing hot and cold water areas to increase the reliability of the readings.

All holes were cased with 2 -inch PVC and sealed at the bottom. The casing was filled with water and the hole backfilled. After stabilization, the gradients were measured at $10 \mathrm{ft}(3 \mathrm{~m})$ intervals, using a Gearhart-0wen temperature probe. Thermal conductivities were estimated by Arthur L. Lange of Amax Inc. Gradients measured by Amax correlated extremely well with CGS data (Table 6). 
TABLE 1. Wells Which Have Encountered Precambrian Rock, Archuleta County, Colorado

\begin{tabular}{|c|c|c|c|c|c|c|}
\hline WELL NAME & LOCATIION & $\begin{array}{c}\text { ELEVATION } \\
\text { (ft above } \\
\text { MSL) }\end{array}$ & $\begin{array}{l}\text { DEPTH } \\
\text { TO PC } \\
(\mathrm{ft})\end{array}$ & $\begin{array}{l}\text { PRE- } \\
\text { CAMBR IAN } \\
\text { LITHOLOGY }\end{array}$ & $\begin{array}{l}\text { DEPTH (ft) } \\
\text { THERMAL } \\
\text { WATER } \\
\text { ENCOUNTERED }\end{array}$ & $\begin{array}{l}\text { WATER } \\
\text { TEMP. } \\
\left({ }^{\circ} \mathrm{C}\right) \\
\end{array}$ \\
\hline $\begin{array}{l}\text { Wirt-Frankl in No. } \\
1 \text { - Sullenberger }\end{array}$ & $35 N 02 W 28$ & 7580 & 1323 & Granite & & \\
\hline $\begin{array}{l}\text { Phillips No. } 1 \\
\text { Crowley }\end{array}$ & $32 \mathrm{~N} 01 \mathrm{E} 12$ & 7672 & 1515 & Quartzite & & \\
\hline $\begin{array}{c}\text { Cameron No. } 1 \\
\text { Bramwell }\end{array}$ & $33 N 01 E$ & 8000 & 2300 & & & \\
\hline $\begin{array}{l}\text { Hughes No. } 51 \\
\text { Gramp's }\end{array}$ & 33 NO2E 24 & 8100 & 2217 & & & \\
\hline $\begin{array}{l}\text { Dutch Crowley } \\
\text { Artesian Well }\end{array}$ & $\begin{array}{l}32 \mathrm{NO} 2 \mathrm{E} \\
19 \mathrm{ADD}\end{array}$ & 7752 & 1732 & Quartzite & $1732-1741$ & 70 \\
\hline $\begin{array}{l}\text { Hughs No. } 1 \\
\text { Johnny Miller }\end{array}$ & $32 \mathrm{~N} 03 \mathrm{E} \cdot 2$ & 9010 & 4148 & & & \\
\hline $\begin{array}{l}\text { Eoff Artesian } \\
\text { Well }\end{array}$ & $\begin{array}{l}34 \mathrm{~N} 01 \mathrm{~W} \\
18 \mathrm{AB}\end{array}$ & 7160 & 1303 & Quartzite & $1313-1327$ & 39 \\
\hline $\begin{array}{l}\text { P-1 } \\
\text { (CGS Test Well) }\end{array}$ & $\begin{array}{l}35 \mathrm{NO2W} \\
13 \mathrm{CADC5} 5\end{array}$ & 7060 & 1371 & $\begin{array}{l}\text { Granitel } \\
\text { Quartzite }\end{array}$ & $1371-1483$ & 44 \\
\hline
\end{tabular}

TABLE 2. Inventory of Thermal Spring Vents, Pagosa Springs, Colorado

\begin{tabular}{llllll}
$\begin{array}{l}\text { Vent } \\
\text { Number }\end{array}$ & $\begin{array}{l}\text { Temp. } \\
\left({ }^{\circ} \mathrm{C}\right)\end{array}$ & $\begin{array}{l}\text { Discharge } \\
(\mathrm{gpm})\end{array}$ & $\begin{array}{c}\text { Elevation } \\
(\mathrm{ft})\end{array}$ & $\begin{array}{c}\text { Conductance } \\
(\mathrm{mmhos} / \mathrm{cm})\end{array}$ & $\mathrm{pH}$ \\
\hline A & 55 & 0 & 7077 & 4200 & 6.5 \\
B & 44 & $50-75$ & 7065 & 4050 & \\
C & 41 & $25-35$ & 7060 & 4150 & \\
D & $43-49$ & $\begin{array}{l}\text { less than } \\
1 \text { gpm for }\end{array}$ & 7063 & & \\
& & & & & \\
each vent & & & & \\
E & 55 & & 7073
\end{tabular}


TABLE 3. Chemical Analysis of Hot Spring Vent A, Pagosa Springs, Colorado

Constituents

Arsenic (As)

Boron (B)

Cadium (Cd)

Calcium ( $\mathrm{Ca}$ )

Chloride (C1)

Fluoride (F)

Iron (Fe)

Lithium ( $L i)$

Magnesium ( $\mathrm{Mg}$ )

Manganese ( $M n$ )

Mercury ( $\mathrm{Hg})$

$\mathrm{Nitrogen}(\mathrm{N})$

Phosphate $\left(\mathrm{PO}_{4}\right)$

Ortho diss. as P.

Ortho

Potassium (K)

Selenium ( $\mathrm{Se}$ )

Silica $\left(\mathrm{SiO}_{2}\right)$

Sodium $(\mathrm{Na})^{2}$

Sulfate $\left(\mathrm{SO}_{4}\right)$
Zinc $(\mathrm{Zn})$

Alkal inity

As Calcium Carbonate

As Bicarbonate

Hardness

Noncarbonate

Total

Specific conductance

(Micromohs):

Total dissolved

solids (TDS)

$\mathrm{pH}$, Field

Discharge (gpm):

Temperature $\left({ }^{\circ} \mathrm{C}\right)$ :

From Barrett and Pearl (1976)
Concentration

$(\mathrm{Mg} / \mathrm{T})$

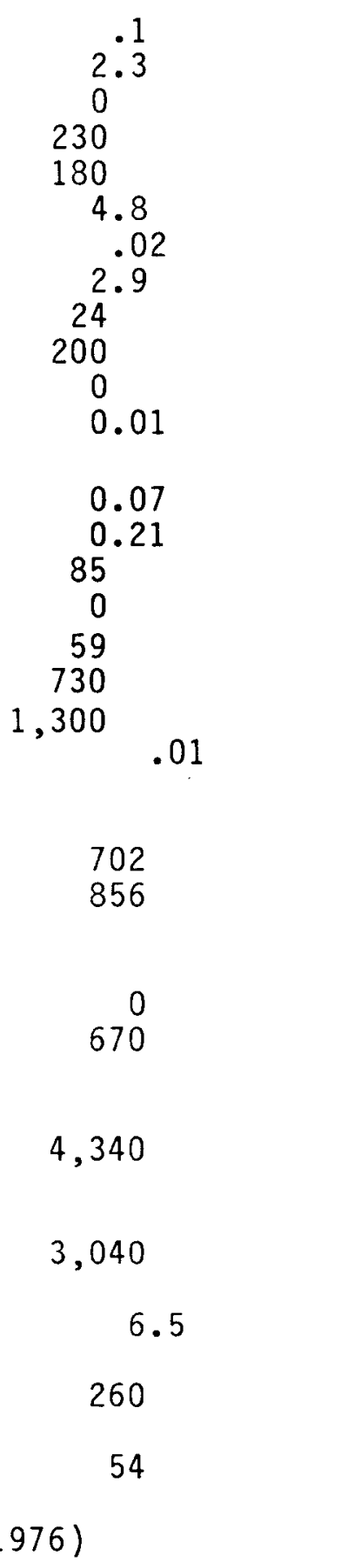


TABLE 4. Thermal Well Inventory, Pagosa Springs, Colorado

\begin{tabular}{|c|c|c|c|c|c|c|c|c|c|c|c|c|}
\hline $\begin{array}{l}\text { WELL } \\
\text { LOCATION }\end{array}$ & $\begin{array}{l}\text { TEMP. } \\
\text { ('C) }\end{array}$ & $\begin{array}{l}\text { ELEVATION } \\
\text { (ft above } \\
\text { MSL) }\end{array}$ & $\begin{array}{l}\text { WELL } \\
\text { DEPTH } \\
(\mathrm{ft})\end{array}$ & $\begin{array}{l}\text { CASING } \\
\text { DIA. } \\
\text { (in) }\end{array}$ & $\begin{array}{c}\text { PRESSURE } \\
\text { (PSI)* }\end{array}$ & $\begin{array}{l}\text { NATER LEVE } \\
\text { DATE } \\
\text { MEAS. }\end{array}$ & $\begin{array}{l}\text { EL } \\
\text { ELEVATION } \\
\text { (ft above } \\
\text { MSL) }\end{array}$ & & USE & $\begin{array}{l}\text { YIELD } \\
\text { (GPM) }\end{array}$ & AQUIFER & $\begin{array}{l}\text { DATE DR ILLED } \\
\text { OR ABANDONED } \\
\text { OWNER } \\
\end{array}$ \\
\hline \multicolumn{13}{|l|}{$35 \mathrm{~N} 02 \mathrm{~W}$} \\
\hline 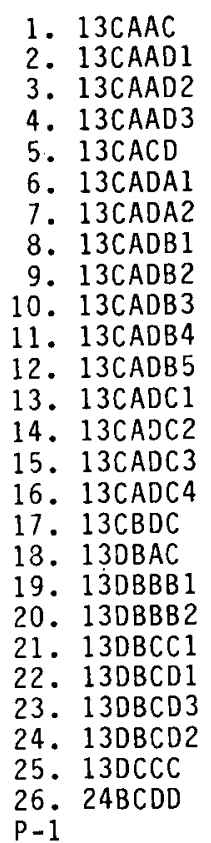 & $\begin{array}{c}54 \\
59 \\
54 \\
54-67(?) \\
56 \\
56 \\
44+ \\
57 \\
31 \\
34 \\
51\end{array}$ & $\begin{array}{l}7100 \\
7090 \\
7090 \\
7085 \\
7075 \\
7078 \\
7078 \\
7079 \\
7080 \\
7080 \\
7080 \\
7080 \\
7063 \\
7063 \\
7063 \\
7065 \\
7100 \\
7065 \\
7100 \\
7100 \\
7065 \\
7065 \\
7065 \\
7065 \\
7080 \\
7030\end{array}$ & $\begin{array}{r}282 \\
35 \\
85 \\
35 \\
85 \\
\\
468 \\
\\
\\
385 \\
400+ \\
\\
400+ \\
213 \\
500\end{array}$ & 4.5 & $\begin{array}{l}36.5 \\
\text { Flowing } \\
\text { Flowing } \\
\text { Flowing } \\
\text { Flowing } \\
36.5 \\
\text { Flowing } \\
\text { Flowing } \\
\text { Flowing } \\
\text { Flowing } \\
\text { Flowing } \\
\text { Flowing } \\
\text { Flowing } \\
\text { Flowing } \\
\text { Flowing } \\
\text { Flowing } \\
\text { Flowing } \\
\text { Flowing }\end{array}$ & $12 / 14 / 79$ & 7120 & $\begin{array}{l}1 . \\
2 . \\
3 . \\
4 . \\
5 . \\
6 . \\
7 . \\
8 . \\
9 . \\
10 . \\
11 . \\
12 . \\
13 . \\
14 . \\
15 . \\
16 . \\
17 . \\
18 . \\
19 . \\
20 . \\
21 . \\
22 . \\
23 . \\
24 . \\
25 . \\
26 .\end{array}$ & $\begin{array}{l}H \\
H \\
A \\
A \\
A \\
H \\
T / M \\
A \\
H \\
U \\
H \\
H \\
H \\
H \\
H \\
A \\
U \\
H \\
U \\
Y \\
M \\
M \\
A \\
U \\
R \\
R \\
R \\
C \\
S \\
A\end{array}$ & $\begin{array}{c}140(?) \\
3-500 \\
100 \\
50-100\end{array}$ & $\begin{array}{l}M ? / D \\
M ? / D \\
M \\
M \\
M \\
D / M r \\
D \\
D ? / M r \\
D ? / M r . \\
M ? / D ? \\
D ? / M r .\end{array}$ & $\begin{array}{l}\text { 1968; Methodist Church } \\
1920 \text { 's; Superior Auto } \\
1975 \text {; Universal Telephone } \\
1964 \text {; Rexall Drug } \\
\text { Vic Poma } \\
1954 ; \text { Pagosa Springs } \\
\text { Pagosa Springs } \\
1955 \text {; Buhler } \\
\text { Citizen's Bank } \\
1900 \text { 's; Adobe Inn } \\
\text { Mark Wilsey } \\
1921 ; \text { Glen Edmonds } \\
1930 ; \text { Archuleta County } \\
1920 ; \text { Archuleta County } \\
\text { 1935; Archuleta County } \\
\text { Vic Poma } \\
\text { Archuleta County } \\
1960 ; 0 . \text { L. Sanders } \\
\text { School District No. } 50 \\
\text { School District No. } 50 \\
\text { Spring Inn } \\
\text { Mike Giordano } \\
1954 ; \text { Mike Giordano } \\
\text { Mike Giordano } \\
\text { Morgan } \\
\text { School District No. } 50\end{array}$ \\
\hline $\begin{array}{l}\frac{1}{13 A} \operatorname{CDC} 5 \\
0-2\end{array}$ & 44 & 7060 & 1483 & 6 & 84 & $11 / 28 / 78$ & 37254 & & $u$ & 200 & $\mathrm{pC}$ & 1978; CGS (Temporary) \\
\hline $\begin{array}{l}\frac{13 A}{13 A C D} 6 \\
32 N 01 E\end{array}$ & 44 & 7060 & 790 & 6.5 & 60 & $8 / 15 / 78$ & 7199 & & u & 500 & $\mathrm{D} / \mathrm{Mr}$. & 1978; CGS (Temporary) \\
\hline $\begin{array}{l}\text { 19ADD } \\
34 N 01 \mathrm{~W}\end{array}$ & 70 & 7742 & 1741 & 8 & Flowing & & & & I & 225 & $\mathrm{pC}$ & Crowl ey \\
\hline $7 \mathrm{CDD}$ & 39 & 7120 & 1331 & 8 & Flowing & & & & I & 300 & $\mathrm{pC}$ & Griffith \\
\hline
\end{tabular}

Explanation:

$\begin{array}{ll}\frac{U S E}{H}-\text { Heating } & M-\text { Melting Snow } \\ A-\text { Abandoned } & R \text { - Recreation } \\ U \text { - Unused } & I \text { - Irrigation } \\ T \text { - Tourist Attraction } & S \text { - Stock }\end{array}$

AQUIFERS

- Mancos Shale

D - Dakota Sandstone

Mr - Morrison Formation

pC - Precambrian Basement

*Pressures were not measured on most wells. Refer to text.

Sequential numbers refer to well locations on Plate 2 . 
TABLE 5. Chemical analyses of water from thermal wells, Pagosa Springs, Colorado

CONCENTRATIONS $(\mathrm{Mg} / 1)$

Constituents

35 N02W13CADC1 35N02W13DBCD1

$34 N 01 W 18 A B$

Arenic (As)

Boron (B)

Cadium ( $\mathrm{Cd}$ )

Calcium ( $\mathrm{Ca}$ )

Chloride (CI)

Fluoride (F)

Iron (Fe)

Lithium ( $\mathrm{Li}$ )

Magnesium (Mg)

Manganese (Mn)

Mercury $(\mathrm{Hg})$

Nitrogen (N)

Phoshate $\left(\mathrm{PH}_{4}\right)$

Ortho diss. as $P$

Ortho

Potassium (K)

Selenium ( $\mathrm{Se}$ )

Silica $\left(\mathrm{SiO}_{2}\right)$

Sodium $(\mathrm{Na})^{2}$

.09

.09
.8

0

170

4.5

.02

2.8

25

.27

0

1.98
0
230

160

4.4

.21

2.9

24

$0^{.25}$

.02
0
640
20

2.6

3.0

.4
.0

29

$0^{.22}$

Sulfate $\left(\mathrm{SO}_{4}\right)$

Zinc ( $Z n)$

0.05

0.15

Alkalinity

As Calcium Carbonate

As Bicarbonate

Hardness

Noncarbonate

Total

89

0

52

780

1,500

.01

0

0.04

0.12

91

0

22

51

780

45

160

1,600

.01

1,800

704

858

618

753

175

213

23
730

56

670

1,500

Specific conductance

(Micromohs):

6,300

6,000

2,500

Total dissolved

solids (TDS)

ph, Field

3,320

6.5

3,320

30

Discharge (gpm):

Temperature $\left({ }^{\circ} \mathrm{C}\right)$ :

56

6.5

53
2,830 7.0 50

39

From Barrett and Pearl (1976) 
Table 6. Geothermal Gradients and Heat Flow

\begin{tabular}{|c|c|c|c|c|c|c|c|}
\hline $\begin{array}{l}\text { Hole } \\
\text { Number. }\end{array}$ & $\begin{array}{l}\text { Tota1 } \\
\text { Depth }(M)\end{array}$ & $\begin{array}{c}\text { Formation } \\
\text { at T.D. }\end{array}$ & $\begin{array}{c}\text { Gradient } \\
1,{ }^{\circ} \mathrm{C} / \mathrm{km}(1)\end{array}$ & $\begin{array}{l}\text { Gradient } \\
2, \mathrm{C} / \mathrm{km}\end{array}$ & $\begin{array}{l}\text { Gradient } \\
3,{ }^{8} \mathrm{C} / \mathrm{km}\end{array}$ & $\begin{array}{l}\text { Gradient } \\
4,{ }^{\circ} \mathrm{C} / \mathrm{km}\end{array}$ & $\begin{array}{l}\text { Heat Flow } \\
(\text { H.F.U.) (2) }\end{array}$ \\
\hline$G-1$ & 48 & $\begin{array}{l}\text { Dakota } \\
\text { Sandstone }\end{array}$ & $\frac{158.9}{158.8}$ & $\therefore \frac{127.5}{130.8}$ & $\frac{58.3}{78.0}$ & & 4.76 \\
\hline$G-2$ & 87 & $\begin{array}{l}\text { Mancos } \\
\text { Shale }\end{array}$ & $\frac{114.1}{78.0}$ & $\frac{52.0}{56.1}$ & $\frac{200.3}{146.4}$ & $\frac{132.7}{113.4}$ & 4.17 \\
\hline$G-3$ & 86 & $\begin{array}{c}\text { Dakota } \\
\text { Sandstone } \\
(?)\end{array}$ & $\frac{55.6}{37.8}$ & $\frac{230.7}{159.0}$ & $\frac{101.7}{96.6}$ & & 3.59 \\
\hline$G-4$ & 84 & $\begin{array}{c}\text { Dakota } \\
\text { Sandstone } \\
(?)\end{array}$ & $\frac{110.7}{99.8}$ & $\frac{66.0}{59.0}$ & $\frac{153.8}{128.0}$ & & 2.97 \\
\hline $\mathrm{G}-5$ & 88 & $\begin{array}{l}\text { Mancos } \\
\text { Shale }\end{array}$ & $\frac{83.2}{83.2}$ & $\because$ & & & 3.05 \\
\hline G-6 & 87 & $\begin{array}{l}\text { Mancos } \\
\text { Shale }\end{array}$ & $\frac{78.9}{71.0}$ & $\frac{59.9}{58.7}$ & & & 2.15 \\
\hline $\begin{array}{ll}\text { (1) } & N \\
& G \\
& d \\
\text { (2) } & H\end{array}$ & $\begin{array}{l}\text { erator is } \\
\text { dients } 1- \\
\text { ch curves } \\
\text { flow ca } \\
\text { er to Pla }\end{array}$ & $\begin{array}{l}\text { GS data, de } \\
\text { refer to st } \\
\text { Depth incr } \\
\text { ulations ar } \\
2 \text { for hole }\end{array}$ & $\begin{array}{l}\text { nominator } \\
\text { raight-line } \\
\text { eases from } \\
\text { e from Arth }\end{array}$ & $\begin{array}{l}\text { Amax Inc. } \\
\text { egments of } \\
4 \text { i. Lange }\end{array}$ & $\begin{array}{l}\text { temperatu } \\
\text { f Amax Ir }\end{array}$ & versus & \\
\hline
\end{tabular}


Calculated heat flows show a progression of low to high from east to west across the Pagosa Springs area (Plate 2). However, the validity of hole $G-1$ is questionable because it is only $154 \mathrm{ft}(47 \mathrm{~m})$ deep, compared to approximately 300 $\mathrm{ft}(100 \mathrm{~m})$ for the other 5 holes. The GFI drill rig could not penetrate the Dakota Sandstone, which was encountered at a depth of $154 \mathrm{ft}(47 \mathrm{~m})$.

\section{HYDROLOGY}

\section{Introduction}

The near surface groundwater regime is dominated by the San Juan River and its tributaries and by local structures. As a consequence, the relatively abundant surface water and poor quality water in the shallow aquifers, has limited groundwater development. The varying geology and scarcity of data make any attempt at system definition a generalization at best.

The two main aquifers exploited in the Pagosa area, are the Mancos Shale and Dakota Sandstone, however, a few wells have been drilled in the Morrison Formation. Hot water wells were discussed above and will not be included here. The hot water - cold water relationship will be discussed in the conclusions.

\section{Previous Work}

No known published work discusses the hydrogeology of the Pagosa area. Pearl (1972) briefly comments on the groundwater availability in southern Archuleta and Hinsdale counties. An unpublished U.S. Soil Conservation Service (SCS) map (1969) gives a few well locations and water levels around Archuleta County. Iorns and others (1965) discuss the surface hydrology, including water quality, of the San Juan River drainage basin.

\section{Aquifers}

\section{Alluvium}

The extent and thickness of alluvium in the Pagosa area is both limited and variable. As in the lithologic description, alluvium includes all surficial 
deposits of Holocene age. Many wells in the Pagosa area are completed in the alluvium because of its water bearing charactertistics and shallowness. Groundwater occurs generally under water-table conditions, but may be locally semi-confined. Yields range from $5 \mathrm{gpm}(.31 / \mathrm{s})$ to $60 \mathrm{gpm}(4 \mathrm{1} / \mathrm{s})$ with specific capacities of .1 to $600 \mathrm{gpm} / \mathrm{ft}$ (Table 7). This gives estimated coefficients of transmissivity ranging from $1000 \mathrm{gpd} / \mathrm{ft}$ to $60,000 \mathrm{gpd} / \mathrm{ft}$.

Groundwater in the alluvium is generally good quality due to recharge by the various streams and rivers during high flows. Alluvial groundwaters in the Pagosa area tend to be a calcium bicarbonate type (Iorns and others, 1965). However, in irrigated areas, water returned to the streams via the alluvium tends to be of poorer quality; higher in dissolved solids, particularly sulfate.

\section{Mancos Shale}

The Mancos Shalé is exposed over much of the mapped area, particularly around Pagosa Springs (Plate 1). Most of the wells in this area, are completed in either the Mancos or the Mancos and overlying alluvium and are as much as $200 \mathrm{ft}(60 \mathrm{~m})$ deep (Table 7 ).

Groundwater flow in the Mancos Shale is the result of both fracture and intergranular porosity. Many of the discontinuous sands yield moderate amounts of water under semi-confined conditions. Without being able to identify and correlate specific aquifers, the construction of water level or piezometric surface maps from well data is very difficult. Also, because the water level data are distributed over a 20 year period, the water surface map should be inconsisent and somewhat random. However, in plotting the data, it became apparent that the data are more regular than expected and the resultant contour pattern fits reasonably well with known surface hydrologic conditions (Plate 3, Fig. 1). This may be due to a pervasive fracture network superimposed over the porous units. The fractures may interconnect isolated porous units sufficiently to "smooth out" water pressures within the numerous Mancos aquifers, allowing the formation to become, in a sense, homogeneous. Also, seasonal and annual fluctuations may not be significant with respect to the contour interval chosen (Plate $3, \mathrm{Fig}$. 1). 
The water surface map (Plate 3, Fig. 1) suggests areas of local recharge to the west, north, and east of Pagosa Springs. This may or may not include the area of Mancos exposure adjacent to the Eight Mile Mesa fault southwest of Pagosa Springs. A local discharge area occurs about $2 \mathrm{~km}$ south of Pagosa Springs along the San Juan River. Recharge to the San Juan River may occur along much of its course through the Mancos Shale, but because of limited data, this is not apparent in Plate 3, Fig. 1. These areas of recharge and discharge correlate very well with geologic and topographic conditions.

Yields and specific capacities of wells in the Mancos Shale are highly variable. Yields range from $1-2 \mathrm{gpm}(.06-.12 \mathrm{l} / \mathrm{s})$ to $20-30 \mathrm{gpm}(1.3-2 \mathrm{l} / \mathrm{s})$. Specific capacities range from .01 to $200 \mathrm{gpm} / \mathrm{ft}$ and average $.4 \mathrm{gpm} / \mathrm{ft}$. Many of the higher values are due to reported drawdowns of zero, which may be in error. Estimated coefficients of transmissivity, assuming a storage coefficient of 0.2 , range from less than $100 \mathrm{gpd} / \mathrm{ft}$ to $30,000 \mathrm{gpd} / \mathrm{ft}$. Some of the wells with high specific capacities may also be partially completed in alluvium.

Groundwater quality of the Mancos Shale is generally poor. Total dissolved solids range from 1000 to $2500 \mathrm{mg} / \mathrm{l}$, with particularly high concentrations of sodium, calcium, iron, and sulfate. Dissolved hydrogen sulfide is also common. However, there are undocumented claims of relatively good quality groundwater from the Mancos, and these may be from wells completed in relatively clean discontinuous sands which may be in connection with alluvium.

\section{Dakota Sandstone}

The Dakota Sandstone is exposed along the crest of the Sunetha and Stinking Springs anticlines and on the northeast side of the Eight Mile Mesa fault (Plate 1). Generally, because of economics, wells that are completed in the Dakota Sandstone are limited to areas of Dakota exposure or very thin Mancos Shale (Plate 3, Fig. 2).

Groundwater flow in the Dakota Sandstone is the result of fracture porosity and is confined. Individual aquifers cannot be identified using available data, but it is probable that at least two semi-independent aquifer (fracture) systems exist, separated by black shale sequences. 
Well Inventory, Pagosa Springs Area, Colorado

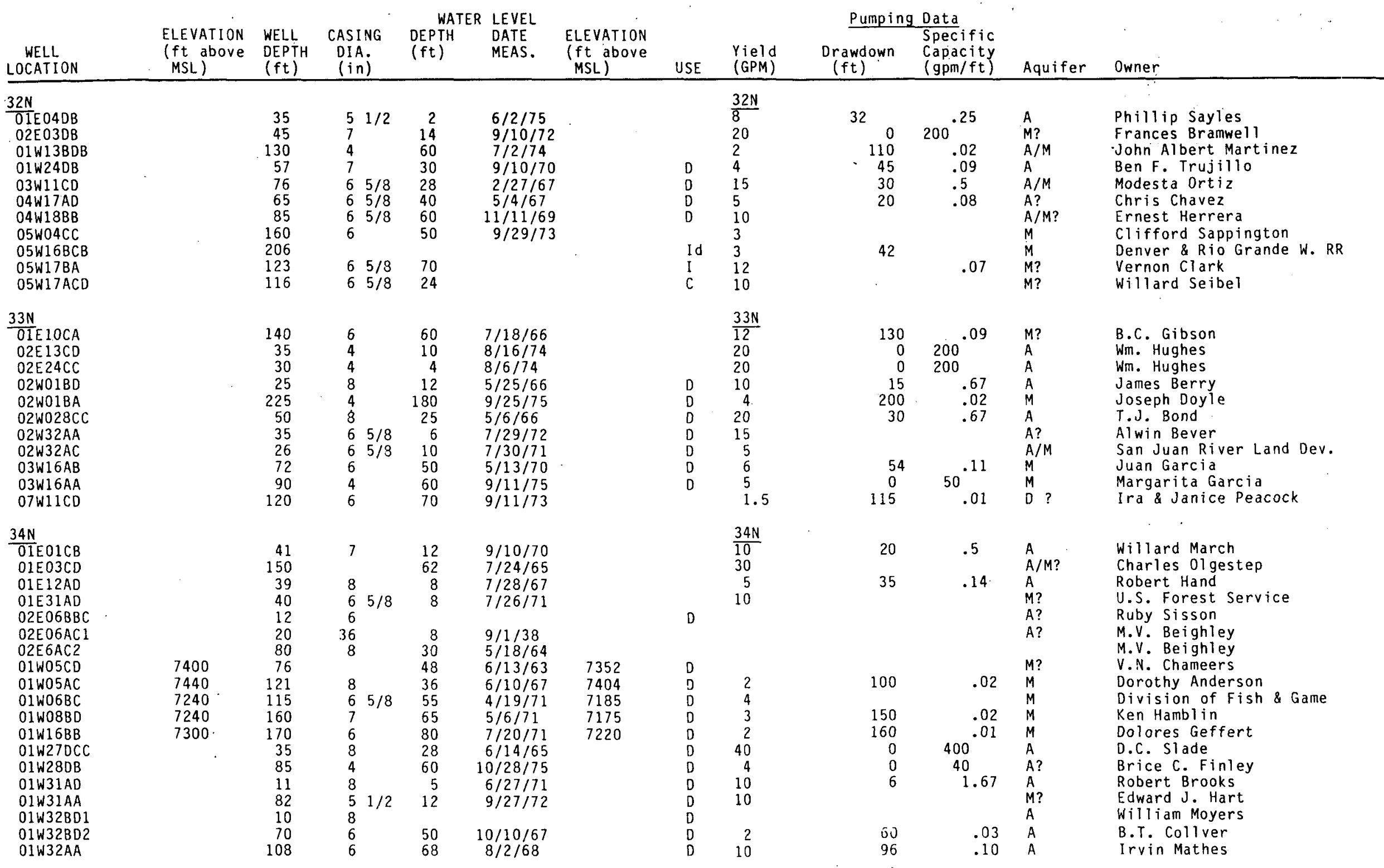




\begin{tabular}{|c|c|c|c|c|c|c|c|c|c|c|c|c|}
\hline $\begin{array}{l}\text { WELL } \\
\text { LOCATION }\end{array}$ & $\begin{array}{l}\text { ELEVATION } \\
(\mathrm{ft} \text { above } \\
\text { MSL) }\end{array}$ & $\begin{array}{l}\text { WELL } \\
\text { DEPTH } \\
(\mathrm{ft})\end{array}$ & $\begin{array}{l}\text { CASING } \\
\text { DIA } \\
(\text { in) }\end{array}$ & $\begin{array}{l}\text { WATE } \\
\text { DEPTH } \\
(\mathrm{ft})\end{array}$ & $\begin{array}{c}\text { ER LEVEL } \\
\text { DATE } \\
\text { MEAS. }\end{array}$ & $\begin{array}{l}\text { ELEVATION } \\
\text { (ft above } \\
\text { MSL) }\end{array}$ & USE & $\begin{array}{l}\text { Yield } \\
\text { (GPM) }\end{array}$ & $\begin{array}{l}\text { Pumpin } \\
\text { Drawdown } \\
(f t)\end{array}$ & $\begin{array}{l}\text { Data } \\
\text { Specific } \\
\text { Capacity } \\
(\text { gpm/ft) }\end{array}$ & Aquifer & Owner \\
\hline 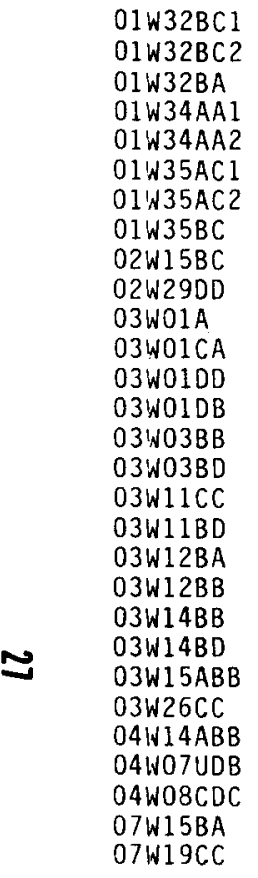 & $\begin{array}{r}6840 \\
6840 \\
7000 \\
\\
\therefore \therefore \\
7150 \\
6780 \\
7360\end{array}$ & $\begin{array}{r}232 \\
150 \\
117 \\
100 \\
20 \\
50 \\
102 \\
16 \\
45 \\
345 \\
100 \\
165 \\
23 \\
110 \\
49 \\
100 \\
140 \\
65 \\
135 \\
70 \\
77 \\
154 \\
40 \\
60 \\
125 \\
135 \\
187 \\
200 \\
95\end{array}$ & $\begin{array}{rr}6 & \\
6 & 5 / 8 \\
7 & \\
6 & \\
4 & \\
6 & \\
6 & \\
60 & \\
6 & \\
5 & \\
4 & \\
5 & 1 / 2 \\
5 & \\
6 & \\
8 & \\
6 & 5 / 8 \\
5 & \\
5 & \\
5 & \\
6 & \\
6 & \\
6 & \\
8 & \\
7 & \\
6 & 5 / 8 \\
7 & \\
7 & \\
7 & \\
5 & 1 / 2\end{array}$ & $\begin{array}{r}150 \\
70 \\
67 \\
40 \\
8 \\
18 \\
15 \\
4 \\
20 \\
140 \\
50 \\
48 \\
8 \\
20 \\
38 \\
81 \\
60 \\
30 \\
16 \\
43 \\
30 \\
85 \\
15 \\
50 \\
50 \\
38 \\
42 \\
115 \\
14\end{array}$ & $\begin{array}{c}9 / 11 / 68 \\
8 / 15 / 69 \\
9 / 25 / 71 \\
8 / 29 / 68 \\
6 / 16 / 76 \\
9 / 1 / 69 \\
6 / 24 / 71 \\
10 / 26 / 74 \\
8 / 27 / 68 \\
5 / 28 / 72 \\
11 / 24 / 73 \\
6 / 21 / 73 \\
11 / 16 / 73 \\
12 / 2 / 75 \\
6 / 65 \\
6 / 25 / 68 \\
10 / 21 / 72 \\
8 / 10 / 74 \\
10 / 5 / 72 \\
9 / 24 / 75 \\
6 / 12 / 75 \\
6 / 10 / 75 \\
6 / 13 / 64 \\
4 / 21 / 67 \\
11 / 24 / 73 \\
6 / 58 \\
3 / 31 / 73 \\
9 / 12 / 73\end{array}$ & $\begin{array}{l}6690 \\
6770 \\
6933\end{array}$ & $\begin{array}{l}D \\
D \\
D \\
D \\
D \\
D \\
D \\
D \\
D \\
D \\
D \\
D \\
D \\
D \\
D \\
D \\
D \\
D \\
D \\
D \\
D \\
D \\
D \\
D \\
D \\
D \\
C\end{array}$ & $\begin{array}{r}1 \\
3 \\
3 \\
10 \\
10 \\
2 \\
6 \\
2 \\
20 \\
2 \\
10 \\
5 \\
7 \\
2 \\
11 \\
10 \\
10 \\
6 \\
9 \\
4 \\
10 \\
5 \\
60 \\
10 \\
2.5 \\
2 \\
14 \\
15\end{array}$ & $\begin{array}{r}105 \\
30 \\
10 \\
40 \\
80 \\
6 \\
20 \\
306 \\
60 \\
140 \\
20 \\
95 \\
\\
\\
108 \\
\\
67 \\
64 \\
58 \\
110 \\
0 \\
60 \\
115 \\
\end{array}$ & $\begin{array}{c}.03 \\
.13 \\
1.0 \\
.05 \\
.08 \\
.33 \\
1.0 \\
.01 \\
.17 \\
.04 \\
.35 \\
.02 \\
\\
.09 \\
.13 \\
.06 \\
.17 \\
.05 \\
600 \\
.17 \\
.02 \\
\\
.29\end{array}$ & $\begin{array}{l}M \\
M \\
M \\
M \\
A \\
M ? \\
M \\
A \\
M \\
M \\
D \\
M \\
A / M ? \\
M \\
M \\
M \\
M \\
M \\
M \\
M \\
M \\
M \\
A \\
M \\
M \\
M \\
M \\
D\end{array}$ & $\begin{array}{l}\text { Dean N. Owens } \\
\text { Bunleson T. Collver } \\
\text { George Buldain } \\
\text { Delbert Hart } \\
\text { Beverly M. Still } \\
\text { Frank Farrar } \\
\text { Frank Farrar } \\
\text { Robert Jewett } \\
\text { Robert Blair } \\
\text { Fred Martinez } \\
\text { Sam \& Peggy Ellis } \\
\text { A.B. Granby } \\
\text { David McNeily } \\
\text { David Bell } \\
\text { J. R. Welch } \\
\text { John Welch } \\
\text { Robert D. Whittington } \\
\text { Tom Fite } \\
\text { Art Hamilton } \\
\text { Hubert Renick } \\
\text { William Morgan } \\
\text { Ralph Oldham } \\
\text { R. L. Tiday } \\
\text { M. W. McGilvray } \\
\text { Colo. Div. of Wildlife } \\
\text { Southern Ute Tribe } \\
\text { Charles Blunden } \\
\text { Floyd \& Arlene Beaver } \\
\text { Donald Anderson }\end{array}$ \\
\hline 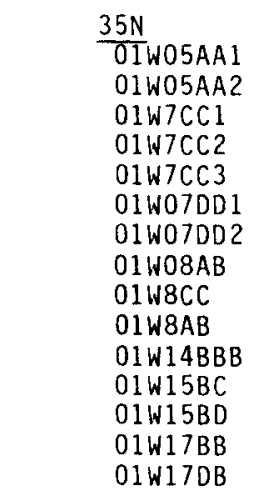 & $\begin{array}{l}7190 \\
7190 \\
7150 \\
7150 \\
7150 \\
7160 \\
7160 \\
7180 \\
7235 \\
7540 \\
7195 \\
7280\end{array}$ & $\begin{array}{l}50 \\
40 \\
41 \\
70 \\
70(?) \\
41 \\
10 \\
220 \\
72 \\
220 \\
25 \\
74 \\
74 \\
105 \\
540\end{array}$ & $\begin{array}{r}6 \\
14\end{array}$ & $\begin{array}{c}8 \\
12 \\
12 \\
20 \\
4 \\
12 \\
4 \\
0 \\
8 \\
0(?) \\
10 \\
36 \\
36 \\
54 \\
0\end{array}$ & $\begin{array}{l}11 / 20 / 65 \\
11 / 24 / 73 \\
4 / 15 / 59\end{array}$ & $\begin{array}{l}7182 \\
7178 \\
7138 \\
7130 \\
7146 \\
7148 \\
7156 \\
7172 \\
7235 ? \\
7504 \\
7141 \\
7280 ?\end{array}$ & $\begin{array}{l}D \\
D \\
D \\
D \\
D\end{array}$ & $\begin{array}{r}\frac{35 \mathrm{~N}}{12} \\
10 \\
6 \\
15 \\
15 \\
6 \\
15 \\
\\
30 \\
4 \\
10 \\
34 \\
15 \\
12\end{array}$ & $\begin{array}{r}20 \\
0\end{array}$ & $340^{.5}$ & $\begin{array}{l}M V \\
M_{V} \\
M_{1} \\
M_{1} \\
M \\
M_{1} \\
A ? \\
D \\
M \\
M \\
A \\
A \\
M V / A \\
M ?\end{array}$ & $\begin{array}{l}\text { James Watkins } \\
\text { James Watkins; Ray T. } \\
\text { V. A. Poma } \\
\text { L. M. Adams } \\
\text { J. B. Hersch, C. McCoy } \\
\text { V. A. Poma } \\
\text { Joseph Hersch } \\
\text { Ward Carpenter } \\
\text { Troy Barber } \\
\text { W. F. Carpenter } \\
\text { P. W. Birdsal1 } \\
\text { Edward Neiman } \\
\text { Edward Neiman } \\
\text { Paul A. Decker } \\
\text { H. Cole }\end{array}$ \\
\hline
\end{tabular}


TABLE 7

Wel1 Inventory, Pagosa Springs Area, Colorado (continued)

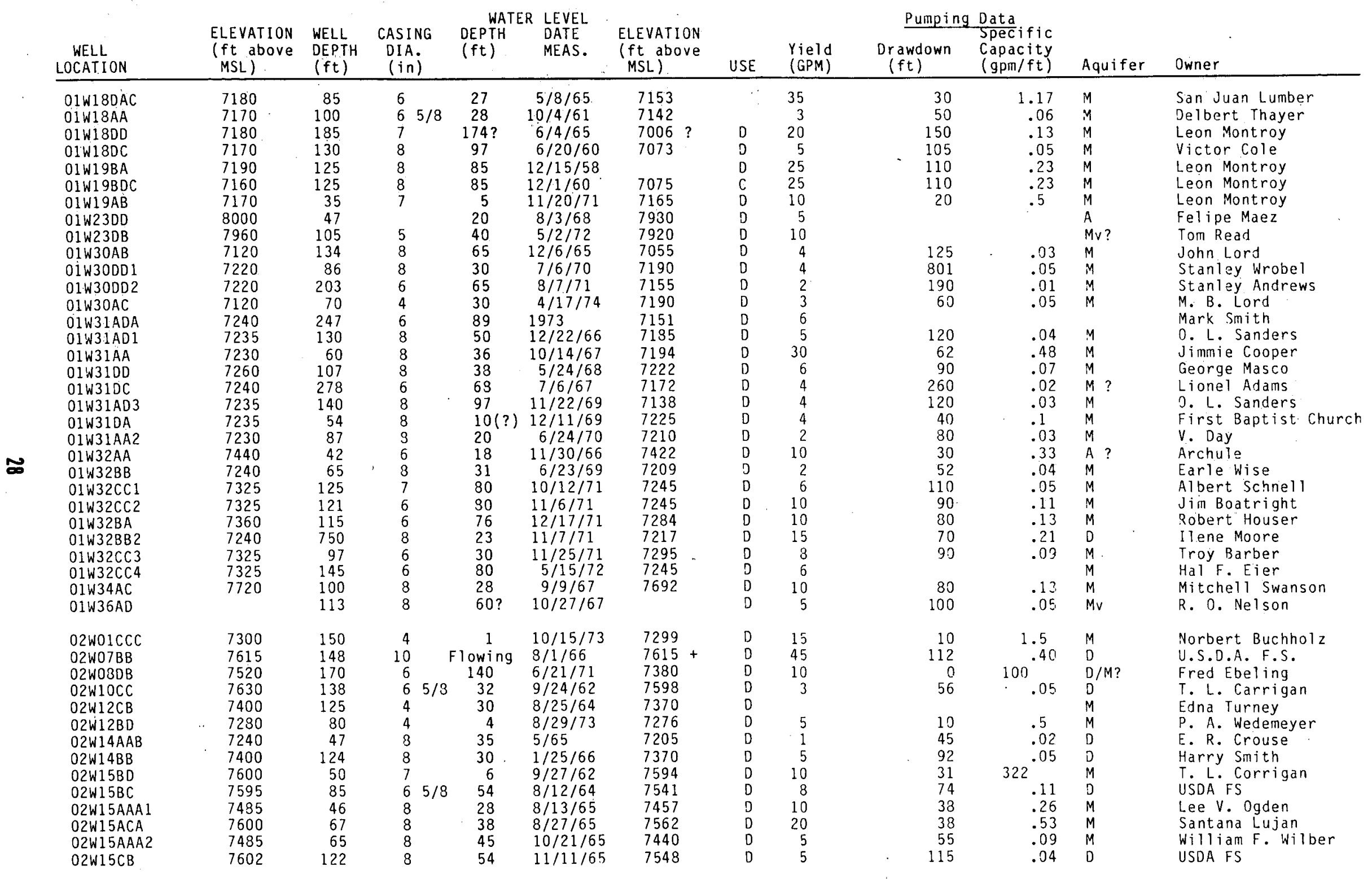




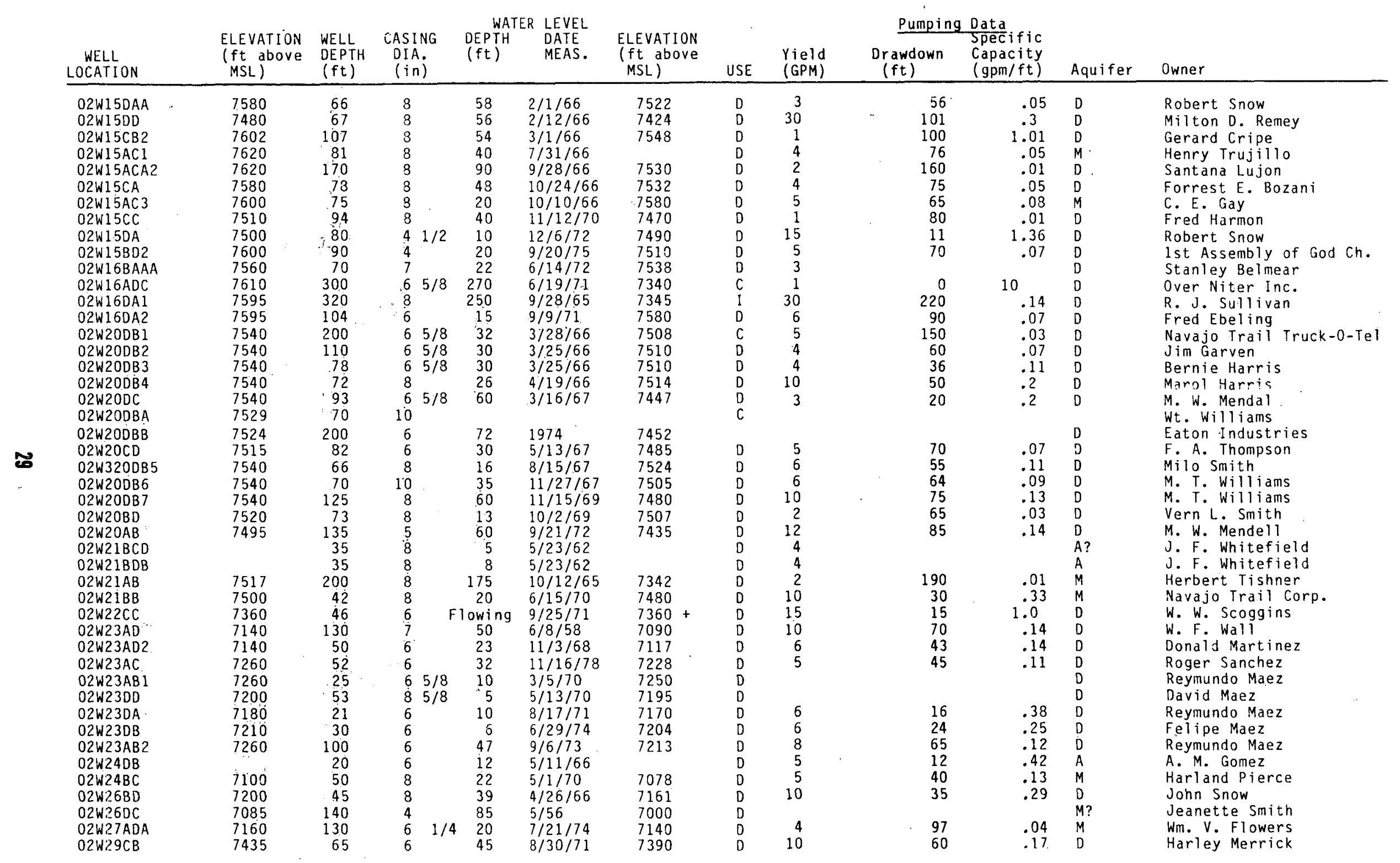


TABLE 7

We11 Inventory, Pagosa Springs Area, Colorado (continued)

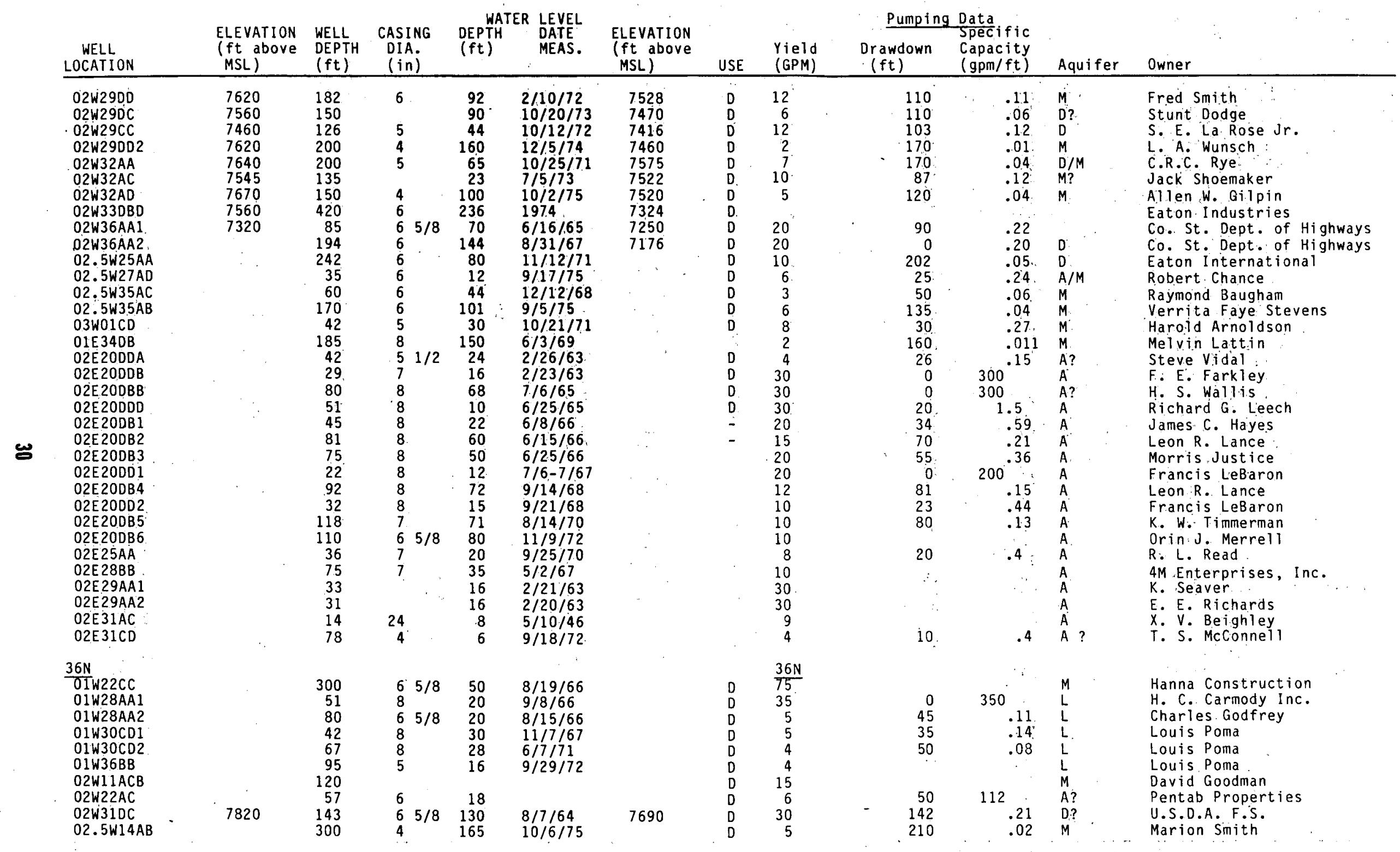




\begin{tabular}{|c|c|c|c|c|c|c|c|c|c|c|c|c|}
\hline $\begin{array}{c}\text { WELL } \\
\text { LOCATION } \\
\end{array}$ & $\begin{array}{l}\text { ELEVATION } \\
\text { (ft above } \\
\mathrm{MSL} \text { ) }\end{array}$ & $\begin{array}{l}\text { WELL } \\
\text { DEPTH } \\
(\mathrm{ft})\end{array}$ & $\begin{array}{c}\text { CASING } \\
\text { DIA. } \\
\text { (in) }\end{array}$ & $\begin{array}{l}\text { DEPTHEF } \\
(\mathrm{ft})\end{array}$ & $\begin{array}{l}R \text { LEVEEL } \\
\text { DATE } \\
\text { MEAS. }\end{array}$ & $\begin{array}{l}\text { ELEVATION } \\
(\mathrm{ft} \text { above } \\
\mathrm{MSL})\end{array}$ & USE & $\begin{array}{l}Y i e^{-1 d} \\
\text { (GPM) }\end{array}$ & $\begin{array}{l}\text { Pumping } \\
\text { Drawdown } \\
\text { (ft) }\end{array}$ & $\begin{array}{l}\text { Data } \\
\text { Specific } \\
\text { Capacity } \\
\text { (gpm/ft) } \\
\end{array}$ & Aqurifer & Owner \\
\hline $03 W 35 B B B$ & & 125 & 8 & 105 & $10 / 20 / 64$ & & D & 1 & 125 & .01 & $D ?$ & S. Gilbert \\
\hline $\begin{array}{l}\frac{37 N}{01 E 16 C C} \\
01 E 20 A D \\
01 E 29 A A \\
03 E 9 D C\end{array}$ & 7000 & $\begin{array}{r}80 \\
18 \\
38 \\
100\end{array}$ & $\begin{array}{rr}6 & 5 / 8 \\
17 & \\
8 & \\
8 & 5 / 8\end{array}$ & $\begin{array}{r}25 \\
6 \\
25 \\
90\end{array}$ & $\begin{array}{l}8 / 12 / 66 \\
10 / 4 / 74 \\
11 / 21 / 67 \\
6 / 10 / 61\end{array}$ & & & $\begin{array}{l}\frac{37 N}{10} \\
10 \\
5 \\
30\end{array}$ & $\begin{array}{r}45 \\
6 \\
35\end{array}$ & $\begin{array}{l}.07 \\
1.7 \\
.14\end{array}$ & $\begin{array}{l}A \\
A \\
A \\
M\end{array}$ & $\begin{array}{l}\text { Charles Ferris } \\
\text { Glen H. Arthur } \\
\text { Frank Teal } \\
\text { John Taylor }\end{array}$ \\
\hline $\begin{array}{l}\frac{38 N}{01 W 13 B D B} \\
03 W 17 C C \\
03 W 19 C D \\
03 W 19 C A D \\
03 W 30 A C C \\
03 W 30 A C \\
03 W 31 A A\end{array}$ & & $\begin{array}{r}131 \\
.62 \\
70 \\
55 \\
28 \\
28 \\
51\end{array}$ & $\begin{array}{ll}7 & \\
8 & \\
7 & \\
7 & \\
8 & \\
8 & \\
8 & 5 / 8\end{array}$ & $\begin{array}{l}72 \\
42 \\
15 \\
12 \\
23 \\
15 \\
41\end{array}$ & $\begin{array}{l}8 / 10 / 64 \\
6 / 2 / 60 \\
9 / 1 / 60 \\
9 / 5 / 60 \\
6 / 10 / 64 \\
8 / 25-27 / 69 \\
6 / 11 / 67\end{array}$ & 9 & $\begin{array}{l}D \\
D \\
D \\
D \\
D \\
D \\
D\end{array}$ & $\begin{array}{r}\frac{38 N}{3} \\
5 \\
15 \\
15 \\
20 \\
10 \\
4\end{array}$ & $\begin{array}{c}83 \\
0 ? \\
0 ? \\
0 ? \\
23 \\
45\end{array}$ & $\begin{array}{l}.04 \\
150 \\
150 \\
200 \\
.44 \\
.09\end{array}$ & $\begin{array}{l}M \\
M \\
M ? \\
M ? \\
A \\
A \\
A ?\end{array}$ & $\begin{array}{l}\text { W. R. Duke } \\
\text { U.S.D.A. F.S. } \\
\text { U.S.D.A. F.S. } \\
\text { U.S.D.A. F.S. } \\
\text { Emmit. Evans } \\
\text { C.B. Norton } \\
\text { U.S.D.A. F.S. }\end{array}$ \\
\hline
\end{tabular}

Explanation:

\section{USE}

$D$ - Domestic
$C$ - Commercia

- Industrial
AQUIFER

A - Alluvium

L - Lewis Shale

M - Mancos Shale

Mv - Mesaverde Formation
D - Dakota Sandstone 
Problems with the Dakota Sandstone data are similar to those discussed for the Mancos Shale. As with the Mancos Shale, the contours drawn from this data seem to fit reasonably well with known geologic and hydrologic conditions.

Areas of recharge, as defined by the piezometric surface map (Plate 3, Fig. 2), correspond extremely well with exposures of Dakota Sandstone (P1ate 1). Plate 3 , Figure 2 indicates that Pagosa Springs may be an area of regional discharge from the Dakota Sandstone. The Dakota is not exposed in this area, suggesting discharge occurs through fractures and/or faults into Mancos Shale and possibly the surface. The delineation of the discharge area, however, does not reflect accurate measurement of hydraulic head on flowing wells within this area.

Adequate well data does not exist to determine the effect of the Eight Mile Mesa fault on the piezometric surface.

\section{Water Quality}

The quality of groundwater from the Dakota Sandstone is highly variable. Much of o the water is very similar to that of the Mancos Shale while some of the water is much lower in total dissolved solids and meets national drinking water standards. Sufficient analyses are not available to make any generalization as to water quality distribution.

\section{Other Aquifers}

Sufficient data are not available to discuss aquifers below the Dakota Sandstone.

\section{DRILLING PROGRAM}

\section{Introduction}

The intention of the CGS test drilling program at Pagosa Springs was to confirm the existence of a thermal reservoir at depth and to evaluate the reservoir with respect to various hydrologic characteristics. Since the intended use of the thermal waters was direct application purposes, a depth 1 imit of $2000 \mathrm{ft}$ (610 $\mathrm{m}$ ) was considered to be the economic limits of this type of development. 
Locating the test well sites proved to be a difficult problem. Geophysical, geological, hydrological and heat flow surveys were not definitive, but indicated that an anomally did exist and was restricted to an area of one square kilometer, centered under the downtown area (Plate 2). However, the main obstacles in locating a drilling site were land ownership and physical space to drill; county, city, and school district land parcels were either too small or located on the fringes of the anomally. Most other land was privately owned.

Fortunate1y, Mr. Bill Lynn, District Water Commissioner, Colorado Division Water Resources, owner of the land between the San Juan River and the county courthouse allowed the use of his land for test drilling. A legal agreement was reached between $\mathrm{Mr}$. Lynn and the county, city and school district regarding the ownership of the well and the sale and distribution of any produced water. Although equipment movement would be somewhat difficult due to several saturated areas, this land would provide easy access to the river for both the disposal and the pumping of water needed in the drilling program. This site also was sufficiently close to existing wells to permit pressure monitoring during drilling and testing phases.

All preliminary work, including well design, location, permits, and contractor selection, started in January, 1978. Since project preliminaries consumed more time than planned and the contractor was delayed by poor weather, the actual drilling was postponed until June 10, 1978. Drilling difficulties, due mostly to large quantities of flowing hot water, required the eventual cutback of the intended program and extension of the entire drilling project schedule. Drilling was finally suspended on September 20, 1978 because of a lack of funds and 1ittle indication of higher temperatures within the targeted depths, $2000 \mathrm{ft}(610 \mathrm{~m})$.

\section{Predrilling Phase}

Using U.S. Department of Energy (DOE) guidelines, an environmental report was prepared by the Denver Research Intitute (Koulet and Armstrong, 1978). This report describes the proposed drilling activity and various environmental aspects of the site. 
Specifications for the drilling program were started in early January, 1978. Existing well data and surface geology were used to determine expected depths to the various formations. The suspected subsurface geology and meager hydrologic data were incorporated in the well designs and locations. Two slim observation holes were planned, one $2000 \mathrm{ft}(610 \mathrm{~m})$ deep, the second $400 \mathrm{ft}(123 \mathrm{~m}) \mathrm{deep}$. The main test hole was to be $2000 \mathrm{ft}(610 \mathrm{~m})$ deep. The three holes were to be located with respect to each other so as to provide the most reliable data during the reservoir testing phase.

Because high volumes of thermal water were expected, discharge to the San Juan River was required during both the drilling and testing phases. This required a discharge permit from the Colorado Department of Health. The request for a permit was submitted January 16, 1978 and permission granted March 27, 1978. The Air Pollution Control Division of the Department of Health determined on March 20 , 1978 that a permit was not required.

In compliance with the Colorado Geothermal Act of 1974 , a drilling permit was required from the Colorado $0 i 1$ and Gas Commission. A permit application was submitted February 8, 1978 and approved by the commission March 20, 1978. Pearl and others (1978) discuss problems associated with the permitting process.

The drilling specifications were submitted to 15 capable drilling contractors in the Rocky Mountain region. Of these, three bids were returned within the specified time. The bids for one test well and two observations holes, as stated above, were as follows:

1) James Drilling Company $\$ 167,773.50$
Wheatridge, Colorado

2) Layne-Western Company, Inc. $\$ 310,840.00$

Denver, Colorado

3) XL Drilling

$\$ 508,752.50$

Montrose, Colorado 
The capabilities of these bidding contractors were evaluated, but because of the bid spread, the ultimate decision had to be based on the lowest bid. Inflation and the high demand for rigs in the Rocky Mountain region resulted in higher bids than expected.

\section{Drilling Phase}

\section{Site Preparation}

The intended site (Fig. 7) did not require much preparation. Vegetation, trash, and large concrete slabs were removed and flow-lines and mud pits were dug. Originally, the flowline was to extend to the San Juan River, but a change in design plans stopped the flowline about $60 \mathrm{ft}(20 \mathrm{~m})$ short, allowing the water to spread, facilitating the cooling (Fig. 7). Water required for drilling was obtained from the San Juan River.

\section{Observation Wells}

$0-1$

This hole was to be a slim $2000 \mathrm{ft}(610 \mathrm{~m})$ deep observation wel1, 0-1. Information gathered from the drilling of this hole would aid in finalizing the design of P-1.

James Drilling Company commenced drilling on June 10, 1978, using a a Speedstar SS-22 drilling rig. Large boulders and unconsolidated soil and sand and gravel required installation of $23.8 \mathrm{ft}(7.4 \mathrm{~m})$ of $10.75 \mathrm{in}$. conductor pipe. Drilling continued rapidly in the Mancos Shale with air-mist until about 300-500 gpm of $56^{\circ} \mathrm{C}$ water was encountered at a depth of $90 \mathrm{ft}(28 \mathrm{~m})$. Drilling continued, using produced water, to the top of the Dakota Sandstone, where $235 \mathrm{ft}(73.4 \mathrm{~m})$ of 8.625 in. surface casing was, installed and cemented. A 10 in. gate valve and a single stack blowout preventer (BOP) were installed on this casing.

An air-percussion hammer was used to drill through the Dakota Sandstone and into the Morrison Formation. The available compressed air was insufficient to lift the large volumes of thermal water encountered in the Dakota Sandstone and to yield 


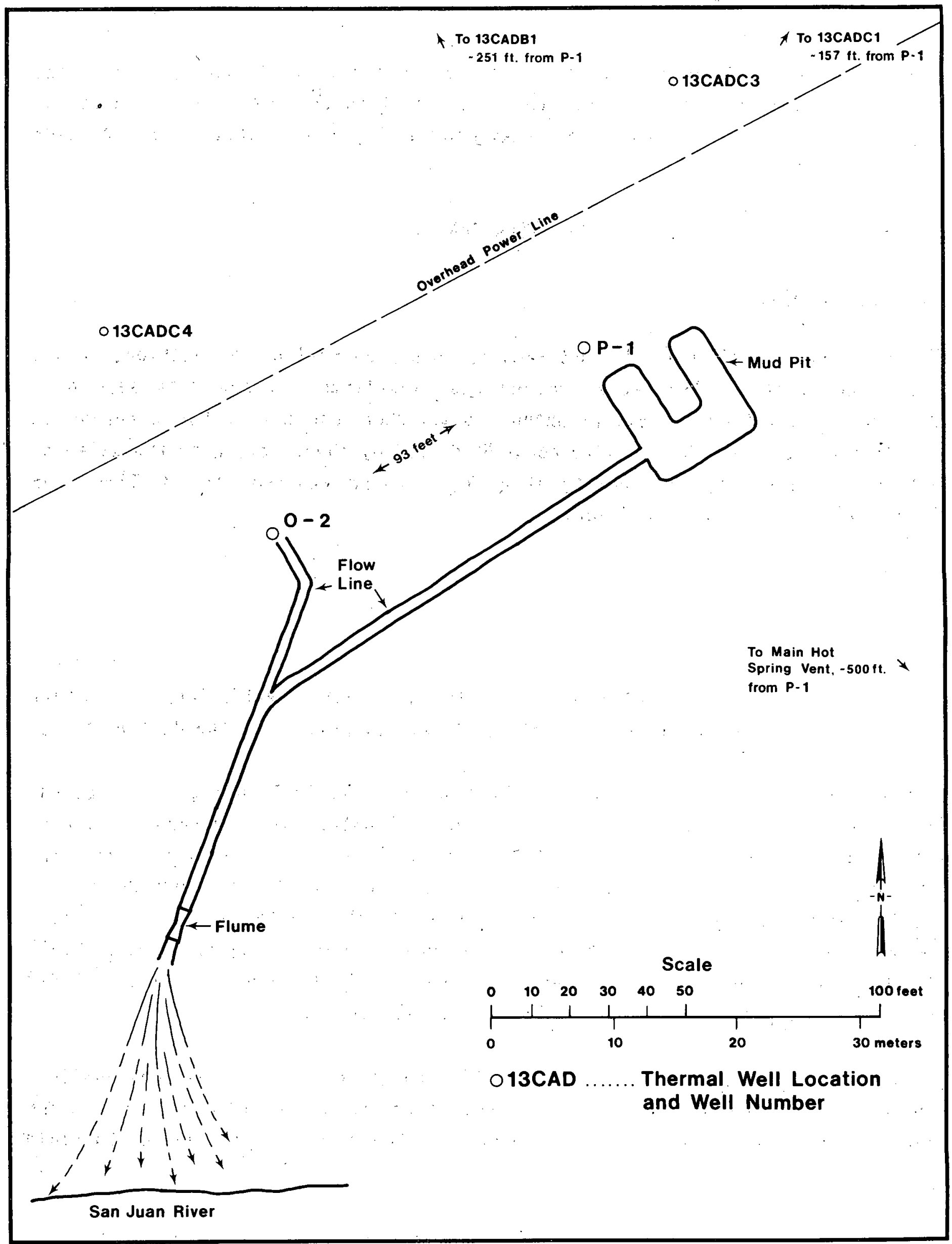

Figure 7 - Site Plan of Test Well Area, Pagosa Springs, Colorado 
footage rates. After the repair of the on-board compressor and the addition of a booster, drilling rates again improved to $1-5 \mathrm{ft} / \mathrm{min}(.03-1.6 / \mathrm{min})$ and only occasionally as low as $.2 \mathrm{ft} / \mathrm{min}(.06 \mathrm{~m} / \mathrm{min})$. On June 30 , a depth of $780 \mathrm{ft}$ (240 m) was reached, but upon entering the hole on July 5, after a 4-day break, the maximum depth achieved was $640 \mathrm{ft}(200 \mathrm{~m})$. Severe caving was occurring between 580 $\mathrm{ft}(181 \mathrm{~m})$ and about $-700 \mathrm{ft}(219 \mathrm{~m})$. After nearly 12 hours all attempts to blow caving material from the hole failed, and there was no further recourse but to abandon 0-1. Mud could not be used because of the relatively high pressure and high volume thermal water at such shallow depths. Casing could not be installed because the hole diameter would then be too small to proceed to $2000 \mathrm{ft}(610 \mathrm{~m})$.

Instead of completely abandoning 0-1, it was decided to designate it 0-2 (Fig. 7), the shallow observation well, and proceed with the large diameter well (P-1), where hopefully the caving could be handled. The option to drill 0-1 later was reserved, dependent on the successful drilling of P-1 and funds remaining.

$P-1$

On July 26, 1978, $12 \mathrm{ft}(3.75 \mathrm{~m})$ of $22 \mathrm{in}$. culvert was installed to avoid potential problems with unconsolidated gravels and boulders resting on the Mancos Shale. Drilling started July 29 with a $20 \mathrm{in}$. rotary bit. Thirty-five feet (10.9 $\mathrm{m})$ of $16 \mathrm{in}$. conductor pipe was installed and cemented. When drilling resumed again on August 15, heavy collars, a reamer, and stabilizer were added to avoid some of the problems encountered in 0-2. It was intended to drill through the caving zone in the Morrison Formation, case, and continue down to the Precambrian basement. However, at a depth of $250 \mathrm{ft}(78 \mathrm{~m})$, a small-displacement fault was encountered which yielded between $1500-2000 \mathrm{gpm}$ of $60^{\circ} \mathrm{C}$ water to the surface. This flow had such a drastic effect on existing wells and the spring that the well had to be cased as soon as possible, precluding any testing. Casing (12.625 in.) was run from the surface to a depth of $265 \mathrm{ft}(83 \mathrm{~m})$ (the interval between $265 \mathrm{ft}[83 \mathrm{~m}]$ and $308 \mathrm{ft}[96 \mathrm{~m}]$ filled with debris from the fault zone) and cemented.

After drilling through the same caving zone as encountered in $0-2$, the hole was cased with $571 \mathrm{ft}(178 \mathrm{~m})$ of $8.875 \mathrm{in}$. casing and cemented. A $7.875 \mathrm{in}$. hole was 


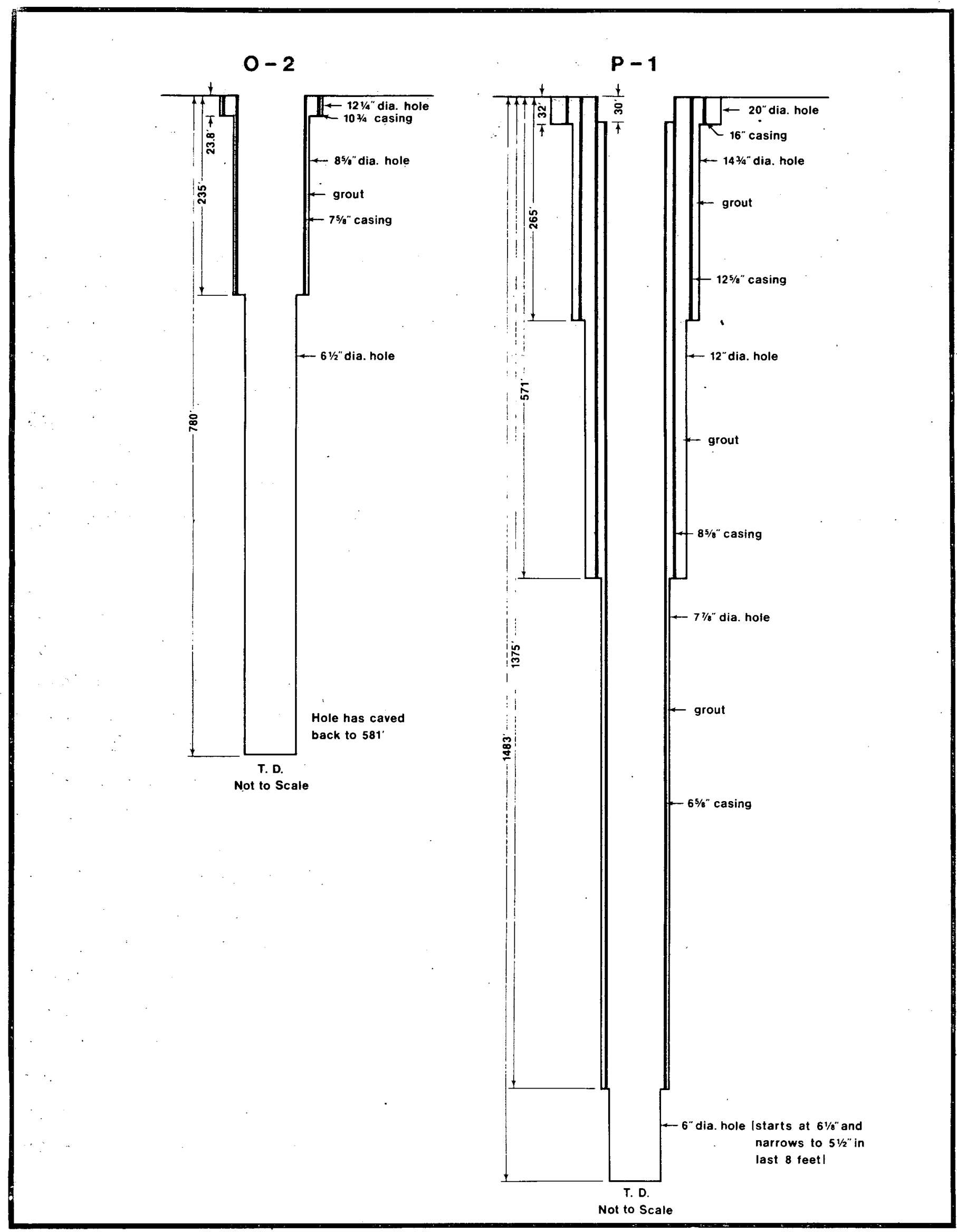

Figure 8 - Well Completion Diagrams of Wells $0-2$ and $P-1$ 
drilled to the top of the Precambrian at $1371 \mathrm{ft}(428 \mathrm{~m})$ where another large flow, 1000-1500 gpm at $45^{\circ} \mathrm{C}$, was encountered. A back-off tool was used to install 6.625 in. casing from the Precambrian basement to within $30 \mathrm{ft}(9 \mathrm{~m})$ of the surface (Fig. 8). After cementing; a 6 in: air-hammer was used to drili to $1475 \mathrm{ft}$ (461 m) in crystalline rock.

A 6 in. diamond core bit was worn out in less than $1 \mathrm{ft}$ in an attempt to core from $1,475 \mathrm{ft}(461 \mathrm{~m})$ because of a tight hole and slight dog-legs. A 5.5 in. diamond core bit was used from $1475-1483^{\mathrm{ft}}(461-463 \mathrm{~m})$, where either as a result of poor bit design and/or fractures, all the diamonds around a lip on the circumference of the bit were worn off, causing the air system to pressure-up. Coring was terminated at $1483 \mathrm{ft}(463 \mathrm{~m})$. Core recovery of only about $75 \%$ was probably due to the intense fracturing.

A series of temperature surveys run under flowing conditions, did not reveal any increases in bottom-hole temperatures. In light of the lower temperatures $\left(45^{\circ} \mathrm{C}\right)$, lateness of the season (people were starting to depend on their wells for heat), and the lack of funds, it was decided to terminate the drilling on September 20 , 1978.

Subsequent temperature surveys run in November, 1978, under shut-in conditions did not show any elevated temperatures (Fig. 13).

\section{Problems}

One of the most difficult and expensive problems was cementing the various casing strings. Haliburton Inc. provided cementing services throughout the project. After the first two attempts at 200 sacks each completely washed out of the hole, a "lhot" ( $\mathrm{CaCl})$, weighted cement was used after cooling the hole with river water for several hours.

The cement problems were never really solved but were minimized by a procedure developed by Mr. Loyd Franzen (see Recommendations). Both cement overruns, which were typically 100-400\%, and extra rig time amounted to a significant cost increase (see Cost Analysis). 
Another problem encountered during the 1 atter part of the project was cement which would not set properly. This was attributed to poor quality cement. Haliburton attempted without much success to locate a better source of cement.

Large volumes of flowing thermal water created numerous problems. Before the BOP and rotating head were installed, wash outs around the rig and burns to the driller and helpers were time consuming and annoying, respectively. Steam on cold mornings, hydrogen sulfide gas, corrosion of metal parts, baking of lubrication from various threaded joints all contributed to the job difficulty. On several occasions, high flows increased the air demand sufficiently to require the addition of more compressors and a booster.

The relatively high water pressure at such shallow depths hindered cementing, casing installation, and the ability to shut the wêll in, prior to the BOP and valve installation.

Equipment failures are common to any drilling program and a fair share of equipment breakdown occurred during the drilling of these two holes. Some of the breakdowns can be attributed to the difficult drilling conditions.

Difficult hole conditions, such as fractured zones, very hard, silicified sandstones, and caving contributed significantly to increased drilling time and equipment failures.

\section{Recommendations}

The procedure developed by Mr. Loyd Franzen, involves staging the cement rather than injecting a caiculated amount plus a large overrun. It was found that a smaller amount of cement was required if it were pumped into the well in stages, allowing each stage adequate time to set prior to injecting the next stage. If the "hot" cement was pumped through as slowly as possible, fractures would be filled, with some loss at the surface. It is not known whether each stage reduced the total water flow, but the staging method seemed to allow the final cement injection to stop the flow easier than one or two large injections of cement, while using less total cement. 
This procedure may be a significant contribution to work under fractured rock and flowing water conditions. The method, however, should be tested under more quantitatively controlled conditions to more fully evaluate the procedure.

The use of a larger rig may have eliminated much of the time-loss due to wash-out beneath the tires of the Speedstar SS-22 rig. Wash-outs would still occur, but would have little affect on a larger rig. Also, a larger rig would have facilitated the installation, and in several cases, the repair of the BOP and large diameter valve.

\section{Cost Analysis}

The maximum contracted amount for the completion of three wells, two at $2000 \mathrm{ft}$ $(610 \mathrm{~m})$ and one at $400 \mathrm{ft}(122 \mathrm{~m})$ deep, was $\$ 167,773.50$. This figure was primarily based on various footage rates for drilling and casing installation.

Despite the partial completion of the project ( $P-1$ to $1483 \mathrm{ft} ., 0-2$ to $780 \mathrm{ft}$.), the total amount expended, excluding direct borehole geophysical logging costs, was $\$ 163,588.82$.

The major cost categories and percentages of the total are given below. The numerator is the actual amount spent and the denominator is the amount attributed to drilling problems, as discussed above.

Cost

Mobilization and Demobilization

Direct Drilling Costs

Casing, Cement, Wellhead

Equipment

Coring

Geophysical Logging (Standby Time)

Total Spent

Total Spent Due to

Problems (as discussed above)

$$
\$ 10,000
$$$$
\frac{71,774}{\$ 15,089}
$$

$\frac{\$ 72,454.82}{\$ 26,511.60}$

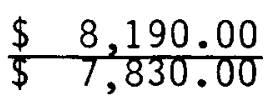

$\$ 1,170.00$

$\$ 163,588.82$

$\$ 49,430.60$
Percentage of Total Cost

$$
6.1 \%
$$

$43.9 \%$

$44.3 \%$

$$
5.0 \%
$$

$0.7 \%$

$100 \%$

$30 \%$ 


\section{TESTING}

The testing phase of the project can be divided into two categories: 1) sample collection and analysis and 2) insitu testing. Sample collection and analysis includes the following:

\author{
Sample collection \\ 1. drift cuttings \\ 2. core
}

3. water
Analysis

Thin section, X-ray, some fluid inclusion

Thin section, $X-r a y$, fluid inclusion, and age date

Standard analysis, trace elements, tritium, and $018 / 0$

\section{Insitu testing}

1. reservoir testing (aquifer tests)

2. drill stem testing

3. pressure monitoring of existing wells

4. semi-continuous monitoring of temperature, $\mathrm{pH}$, conductivity, and discharge

5. borehole geophysics

All of the items under sample collection and analysis have been performed. However, for several reasons, as will be discussed, some items under insitu testing were either deleted or postponed.

\section{Sample Collection and Analysis}

\section{Drill cuttings and Core}

Drill cuttings and core were collected and described during drilling. Because detailed descriptions were performed in the laboratory (Tables 13 and 14), the field descriptions will not be reported and are on file with CGS. Drill cuttings were collected every $20 \mathrm{ft}(6 \mathrm{~m})$ and more frequently when required by lithologic changes. Approximately $8 \mathrm{ft}(2.5 \mathrm{~m})$ of core were recovered from a depth of 1475 to $1483 \mathrm{ft}(450$ to $452 \mathrm{~m})$. 
Standard Analyses

Water samples for the standard analyses were collected in accordance with methods outlined by the U.S. Geological Survey. Various aquifers that were encountered. in both $P-1$ and 0-2 were sampled after isolation by casing (Table 8).

The analyses of water from $P-1$ and $0-2$ test wells are surprisingly similar to analyses of existing shallow wells and springs, 1 isted in Tables 3 and 5 . The total dissolved solids of waters issuing from the basement and the shallow aquifers and hot springs do not vary by more than $200 \mathrm{mg} / 1$. There are, however, slight differences in water chemistry between these zones. When the analyses are plotted on a trilinear diagram, the data points lie along a linear trend in the diamond field (Fig. 9). This indicates that one source of water undergoes base exchange with various clays, exchanging sodium for calcium as the water ascends through various aquifers, while maintaining the same total dissolved solid concentration. Points 1,4 , and 8 , are analyses of water from the basement rocks and indicate a calcium sulfate water type.

Points $2,3,5,6$ and 7 on Figure 9 are a sodium sulfate water and are from the shallow aquifers and the hot springs. There is a slight decrease in sulfate and increase in bicarbonate as the water ascends, but is yet unexplained (Fig. 9). Points 9, 10, and 11 are analyses of nonthermal water from the Dakota Sandstone, Mancos, and Lewis shales, respectively. The validity of number 10, however, is uncertain. Number 12 is a sample from the San Juan River near Pagosa Springs and has less than $100 \mathrm{mg} / 1$ total dissolved solids.

The Precambrian igneous rock, particularly the pegmatitic veining, is probably contributing the relatively high concentrations of boron, flouride, and lithium found in all the thermal water samples (Hem, 1970) (Table 8). The concentrations of these same constituents are much lower or do not occur in analyses of local groundwater. The high concentrations of lead may be associated with the various reduced sulfide species, but the ultimate source within this system is unknown. 


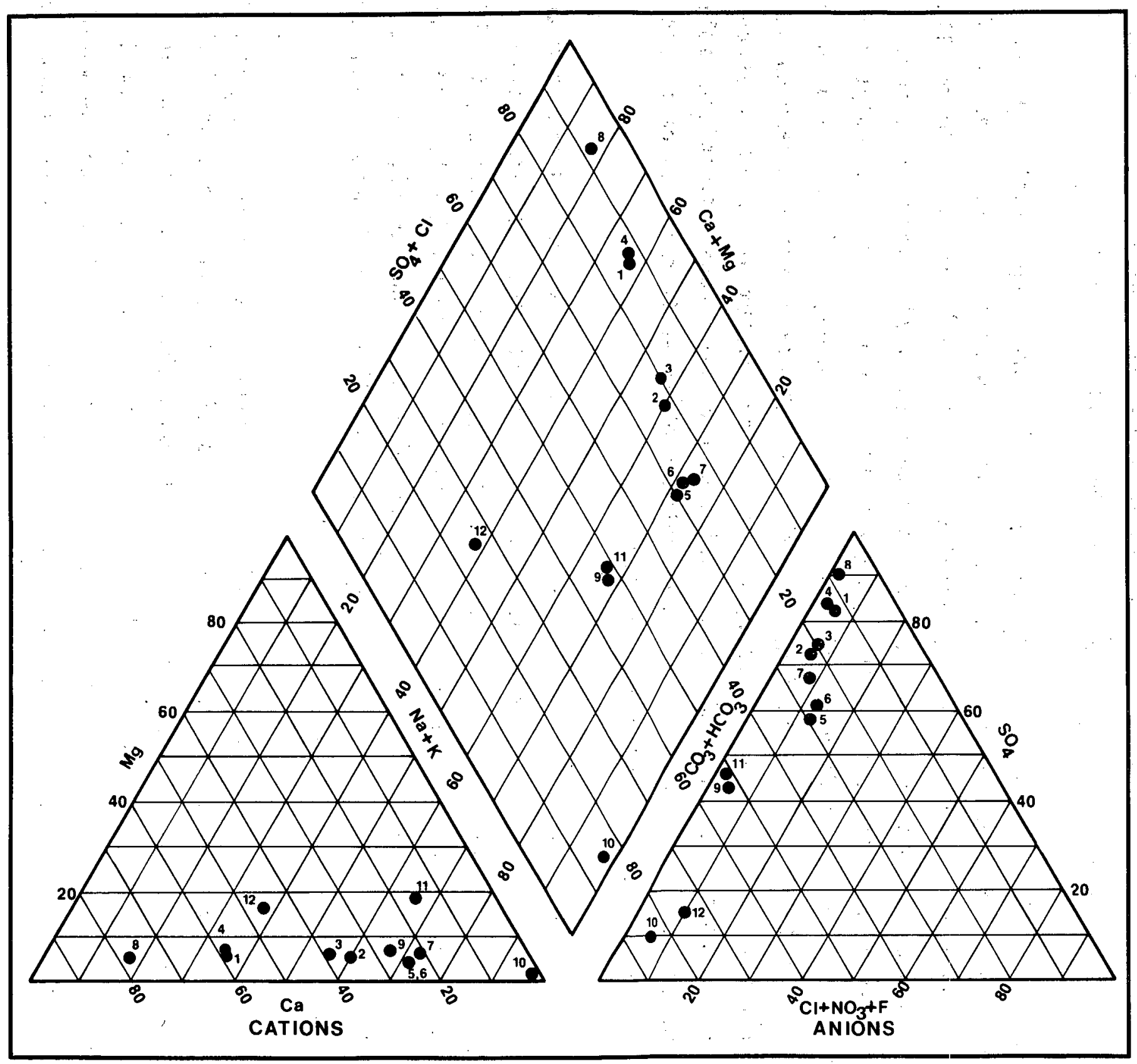

Figure 9 - Trilinear Diagram of Waters from the Pagosa Springs Area 
Explanation for Figure 9, Trilinear Diagram of Waters from the Pagosa Springs Area

Sample Numbers

1

2

3

4

5

6

7

8

9

10

11

12
Location

$P-1,1375-1475 \mathrm{ft}(P C)$

$\mathrm{P}-1,250-585 \mathrm{ft}(\mathrm{Kd}, \mathrm{Jm})$

$0-2,230-572 \mathrm{ft}$ ( $\mathrm{Kd}$ and $\mathrm{Jm}$ )

P-1, 580-1371 ft (Kd through PC)

Spring Vent $A$ (main spring)

Courthouse We11 (13CADC1) 85-90 ft

Spa Motel Well (13CBCD1) (Km?, Kd, Jm)

Eoff Well 1313-1327 ft (PC) $399 \mathrm{ft}$ (Kd)

Tackett Wel1 (34N01W8DBA) $388 \mathrm{ft}(\mathrm{Kd})$

Tackett Well (34N01W8DBA) $263 \mathrm{ft}(\mathrm{Km})$

Ebeling Well (34N03W22CBC) (K1)

Middle Fork Piedra River near

Pagosa Springs (09347200) 
TABLE 8. Chemical Analyses of Thermal Waters from the CGS Test Wells

\section{Well Number $\quad 0-2$ CONCENTRATIONS $\underset{\mathrm{P}-1}{(\mathrm{Mg} / \mathrm{L})}$}

CONSTITUENTS Depth of Sample 230-572 ft $250-585 \mathrm{ft} \quad 580-1371 \mathrm{ft} \quad$\begin{tabular}{c}
$\mathrm{P}-1$ \\
\hline
\end{tabular}

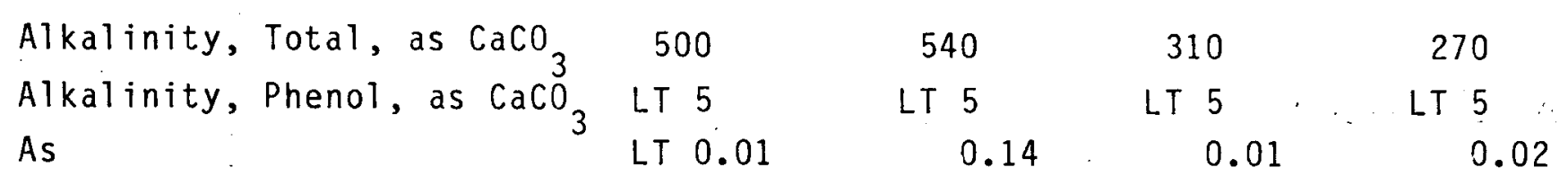

Bicarbonate, as $\mathrm{CaCO}_{3}$

Bi

500

540

310

270

$\begin{array}{lllllllll}0.19 & 0.17 & \text { LT } & 0.1 & 0.1\end{array}$

$\mathrm{Br}$

LT 0.1

LT 0.1

B

$\mathrm{Ca}$

390

340

0.15

0.15

Carbonate, as $\mathrm{CaCO}_{3}$

C1

LT 5

100

$\mathrm{F}$

1.7

LT 5

120

1.4

580

565

LT 5

50

2.6

LT 5

91

.

Hardness as $\mathrm{CaCO}_{3}$

1080

864

0.8

0.08

0.06

2.1

2.4

0.78

39

0.37

35

1550

2.5

1580

$\mathrm{Pb}$

Li

$M n$

- $\mathrm{Mg}$

$\mathrm{Hg}$
$\mathrm{NO}$
$\mathrm{K}$

Silica, as $\mathrm{SiO}_{2}$

$\mathrm{Na}$

Solids, dissolved

LT 0.0002

LT 0.0002

LT 0.01

0.9

LT 0.01

0.06

2.5

65

0.1

1.2

0.08

0.11

1.1

47

0.13

$\mathrm{SO}_{4}$

18.0
600

71

LT 0.0002

LT 0.0002

42

$\mathrm{Zn}^{4}$

3400

1770

0.08

20.7
640
3430
1720
0.03

0.7

LT 0.2

0.7

LT 0.2

42

44

LT: less than 
Two isotopic determinations for oxygen 18 and deuterium were done on the thermal water from the test wells. The determinations for both the shallow water and the water issuing from the Precambrian basement were nearly identical (Table 9).

TABLE 9. Stable Isotope Ratio Analyses

\begin{tabular}{lll} 
Sampled Zone & $D(D / H)$ & $18(018 / 016)$ \\
\hline & & \\
$P-1,571-1068^{\circ}$ & -101 & -13.7 \\
$P-1,1375-1475^{\circ}$ & -99 & -13.9 \\
estimated error is & $+20 / 00$ &
\end{tabular}

If values are plotted on a graph, where 018 is the abscissa and $D$ is the ordinate, points fall on the trend of meteoric and slightly heated groundwaters, as defined by craig (1965) indicating these waters are of meteoric origin.

Tritium Analyses

The results of tritium analysis of all samples from $P-1$ and $0-2$ show the waters to be "dead" with respect to tritium. This implies an age of 25 years or greater (G. W. Gross, written comm., March, 1979). These analyses do not rule out the possibility of mixing young water with large quantities of old water.

\section{Reservoir Characteristics}

A six to ten day reservoir test was to be run when drilling was completed. The test was to include the monitoring of several representative hot wells, $0-2$, and the pumping well P-1. Unfortunately, because of the disruptive nature of flows from the upper portion of the hole., only one short test during drilling at the 90-100 ft (28-31 m) level was run. The major test of the Precambrian basement was postponed until summer 1979 due to the lateness of the season (September 20). The use of existing hot wells by the owners for space heating precluded their being used as observation wells and would introduce serious errors because of cummulative drawdown. 


\section{Aquifer Test}

The courthouse well (13CADC1), completed in the Mancos Shale, and 0-2, completed in the Dakota Sandstone and Morrison Formation were used as observation wells for "pumping" from P-1 (Fig. 7). The uppermost hot water zone, in the Mancos Shale, was tested by air-drilling into and through the producing zone. This procedure may have resulted in some errors because full penetration of the zone was not instantaneous, but rather during a several minute period. Because discharge varied considerably, due to both drilling operations and a pressure drop within the aquifer adjacent to the hole, discharge was monitored along with the pressure in the observation wells.

In Figure 10, the drawdown in psi divided by discharge in gpm is plotted versus time on semi-log paper for the courthouse well. The semi-log plot shows some scattering of data which is probably due to errors in reading the pressure guage and fluctuations in discharge because of of drilling operations. Figure 10 shows a general flattening of the curve and therefore increases in $T$ values with respect to time from 5400 to $24,000 \mathrm{gpd} / \mathrm{ft}$ (Table 10). However, after 50-60 minutes of "pumping" the curve steepens and the transmissivity decreases to $8000 \mathrm{gpd} / \mathrm{ft}$. The inflexions probably represent various boundary conditions, specifically interconnected fractures, each with its own hydraulic characteristics. The storativity values calculated from the semi-log plot range from $.15 \times 10^{-3}$ to 6 $\times 10^{-3}$.

The straightline method of analysis (Fig. 10) is invalid for valves of u greater than .01 (Lohman, 1972), where

$$
\begin{aligned}
& u=\underline{r}^{2} \underline{s} \quad r=\text { radius to pumped well } \\
& \text { 4Tt } \quad S=\text { Storativity } \\
& T=\text { Transmisivity } \\
& t=\operatorname{time} \text { (days) }
\end{aligned}
$$

Since t is generally the only variable which can be controlled in an aquifer test, the $u$ value is most dependent on time or length of the test. Assuming reasonable- 


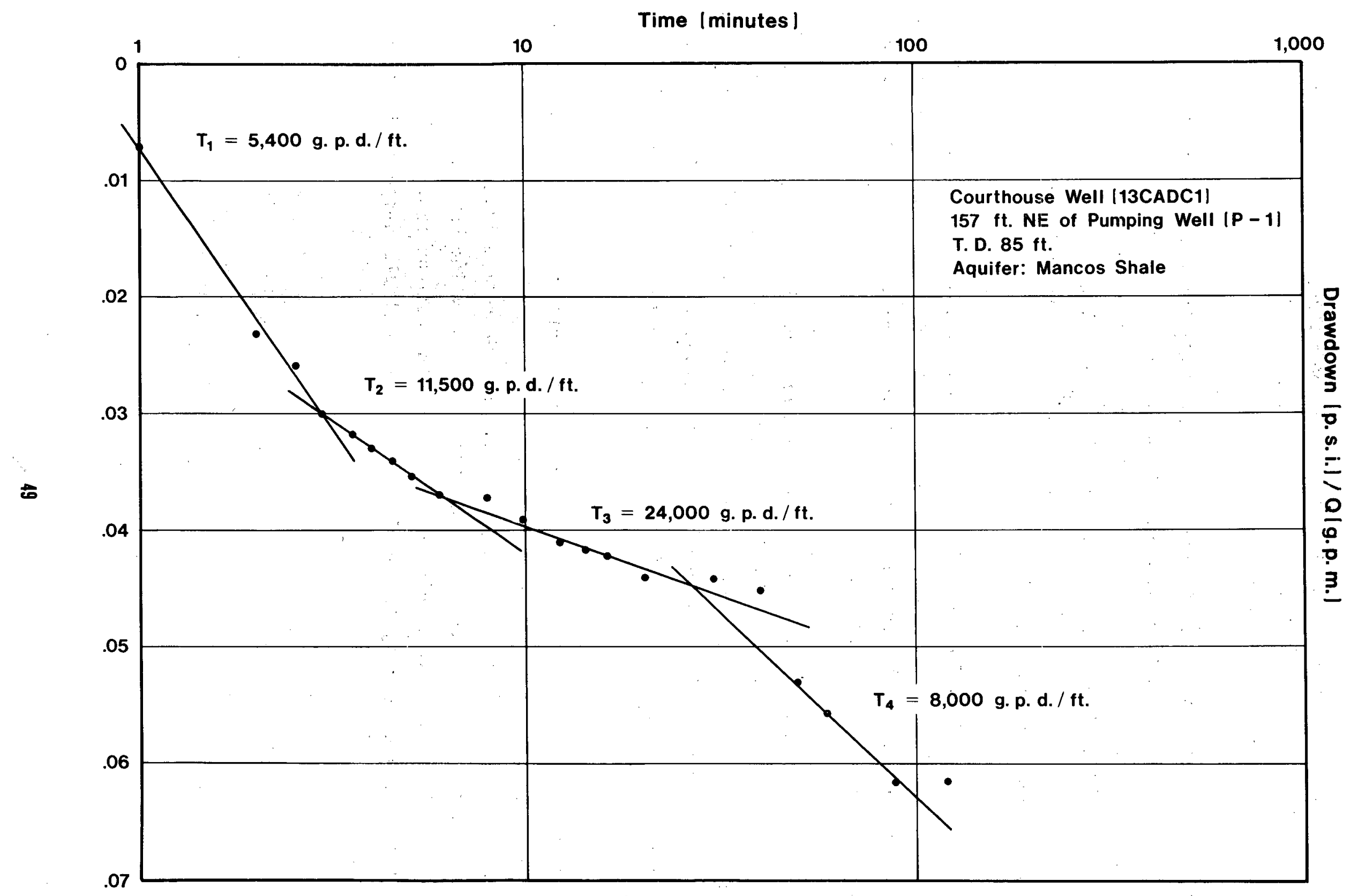

Figure 10 - Time-Drawdown Curve $($ semi- $\log \mid$ of the Courthouse Well 
values of $T$ and $s$, the $u$ calculated with $r$ and $t$ values from this test is less than .01 and it is therefore valid to use the straighti ine or Aron-Scott method (Kruseman and de Ridder, 1970).

Figure 11 is a log-log plot of drawdown versus time for both observation wells. Theis and Hantush-Jacob methods were used to calculate T and S values, which are summarized in Table 10. The Theis values for $T$ and $S$ for the courthouse well range from 2400 to $8400 \mathrm{GPD} / \mathrm{ft}$ and $1.1 \times 10^{-5}$ to $1.3 \times 10^{-7}$,respectively. Values for $0-2$ are $54,000 \mathrm{GPO} / \mathrm{ft}$ and $8.3 \times 10^{-3}$. A single value calculated by the Hantush-Jacob method is $600 \mathrm{GPD} / \mathrm{ft}$.

Several factors reduce the confidence in the accuracy of the calculated $T$ and $S$ values. The test conditions, as discussed above, are a source of considerable error. In addition, the accuracy of calculated values is dependent upon the concepts of the aquifer system.

There is a considerable range in values between the three methods of analysis. The T values calculated by the Theis method are comparable to those of the Aron-scott method, but the Theis $S$ values are at least 2 orders of magnitude lower: Confined aquifers generally. have $S$ values of $10^{-4}$ to. $10^{-5}$. The Hantush-Jacob T value of $600 \mathrm{GPD} / \mathrm{ft}$ is significantly lower than any of the other values:

Beccause drawdown was observed in other aquifers during the test (Fig. 11) and a high degree of hydrologic interconnection was noted during drilling; the results of the test are difficult to interpret. If the interconnectivity reponds as a leaky confined aquifer, then the Hantush-Jacob $T$ value is the most valid. However, if the fault system which interconnects the various aquifers is extremely pervasive, the fracture system would respond as a single anisotropic confined aquifer. 


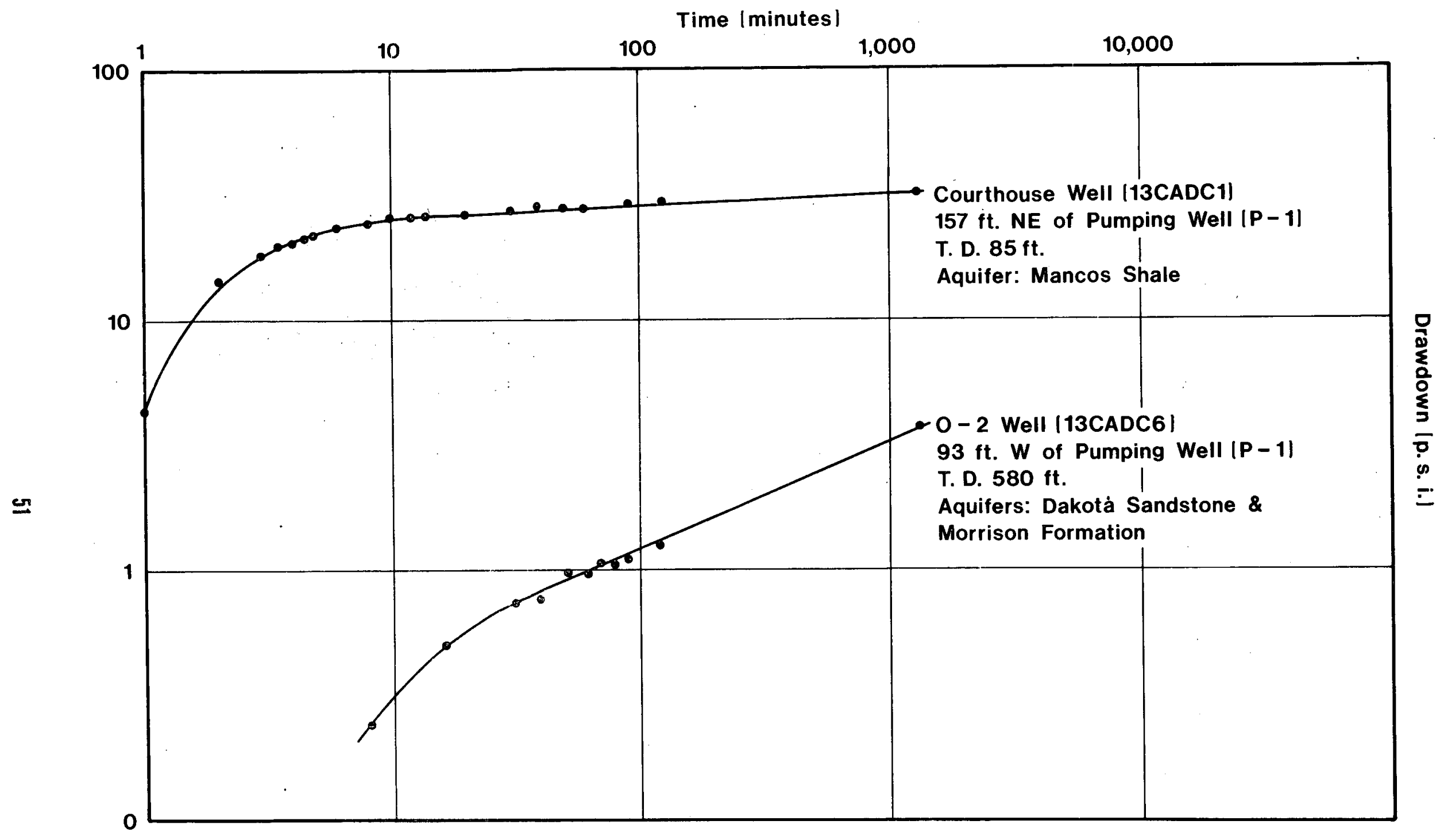

Figure 11 - Time - Drawdown Curves $|\log -\log |$ of Observation Wells 
Unfortunately, the simplicity of this test does not allow for further quantification of this system.

$$
\text { Equations used for Analyses }
$$

Aron-Scott

$$
T=\frac{264}{(S w / Q)}
$$

$$
S=.3 T \cdot\left(t / r^{2}{ }_{w}\right)_{0}
$$

Theis

$$
\begin{aligned}
& T=\frac{114.6(0) W(u)}{s} \\
& S=\frac{T t u}{1.87 r^{2}}
\end{aligned}
$$

Hantush-Jacob

$$
\begin{aligned}
& T=\frac{Q}{4} L(u, v) \\
& S=4 T \frac{t / r^{2}}{1 / u}
\end{aligned}
$$

Where: $T=$ Transmissivity (GPD/ft)

$$
\begin{aligned}
S= & \text { Storativity } \\
& \text { (Dimensionless) }
\end{aligned}
$$$$
Q=F l \text { ow Rate (GPM) }
$$$$
s=\text { Drawdown }(f t)
$$$$
r_{w}=\text { radius of well (ft) }
$$

$$
\begin{aligned}
& r=\text { distance to pumped } \\
& \quad \text { well (ft) } \\
& t=\text { time (days) } \\
& w(u)=\text { well function of } u \\
& u=r^{2} S / 4 T t \\
& L(u, v)=\text { Leakance function } \\
& \quad \text { of } u \text { and } v
\end{aligned}
$$


Temperature, $\mathrm{pH}$, Conductivity, and Discharge

Tables 11 and 12 summarize temperature, $\mathrm{pH}$, conductivity, and flow data collected during drillng from $0-2$ and $P-1$, respectively. Both temperature and conductivity reach a peak in the Dakota Sandstone and show a gradual decrease with depth. pH did not vary by more than a few tenths of a unit. Flow data listed in Tables 11 and 12 are cumulative, except when casing was set. The $40 \%$ increase in flow at $1370 \mathrm{ft}(418 \mathrm{~m})$ in P-1 was due to possible downhole fracturing. A heavy (barite) mud was used to stop flow for casing and cementing, but was instead taken up by unknown formations as the mud was pumped into the hole under pressure. When pressure was released at the surface and the well was allowed to flow again, mud was washed from the hole and flow had significantly increased.

\section{Borehole Geophysics}

It was intended that the entire hole be geophysically logged, but because of high flows and associated problems, the upper $571 \mathrm{ft}(174 \mathrm{~m})$ were cased prior to logging. Selected commercial logs are presented in Figure 12 . The complete original suite of logs are on file with CGS. In addition to the commercial logs, temperature logs were measured on several occassions, using CGS equipment. Selected temperature logs are reported in Figure 13.

\section{Commercial Logs}

Caliper Log: The caliper log shows the hole to be relatively smooth walled and free of wash-outs (Fig. 12). This is probably due more to drilling equipment used rather than the lithology. Because of problems encountered in 0-2 and the upper portions of $P-1$, it was decided to use a reamer and stabilizer for the remainder of $\mathrm{P}-1$.

The major exceptions to the hole uniformity are the large washout beneath the casing at $571 \mathrm{ft}(174 \mathrm{~m})$ and a slight ledge at $1250 \mathrm{ft}(380 \mathrm{~m})$. The water producing zones correlate moderately well with fractures, as indicated by the caliper log (Fig. 12 ). 


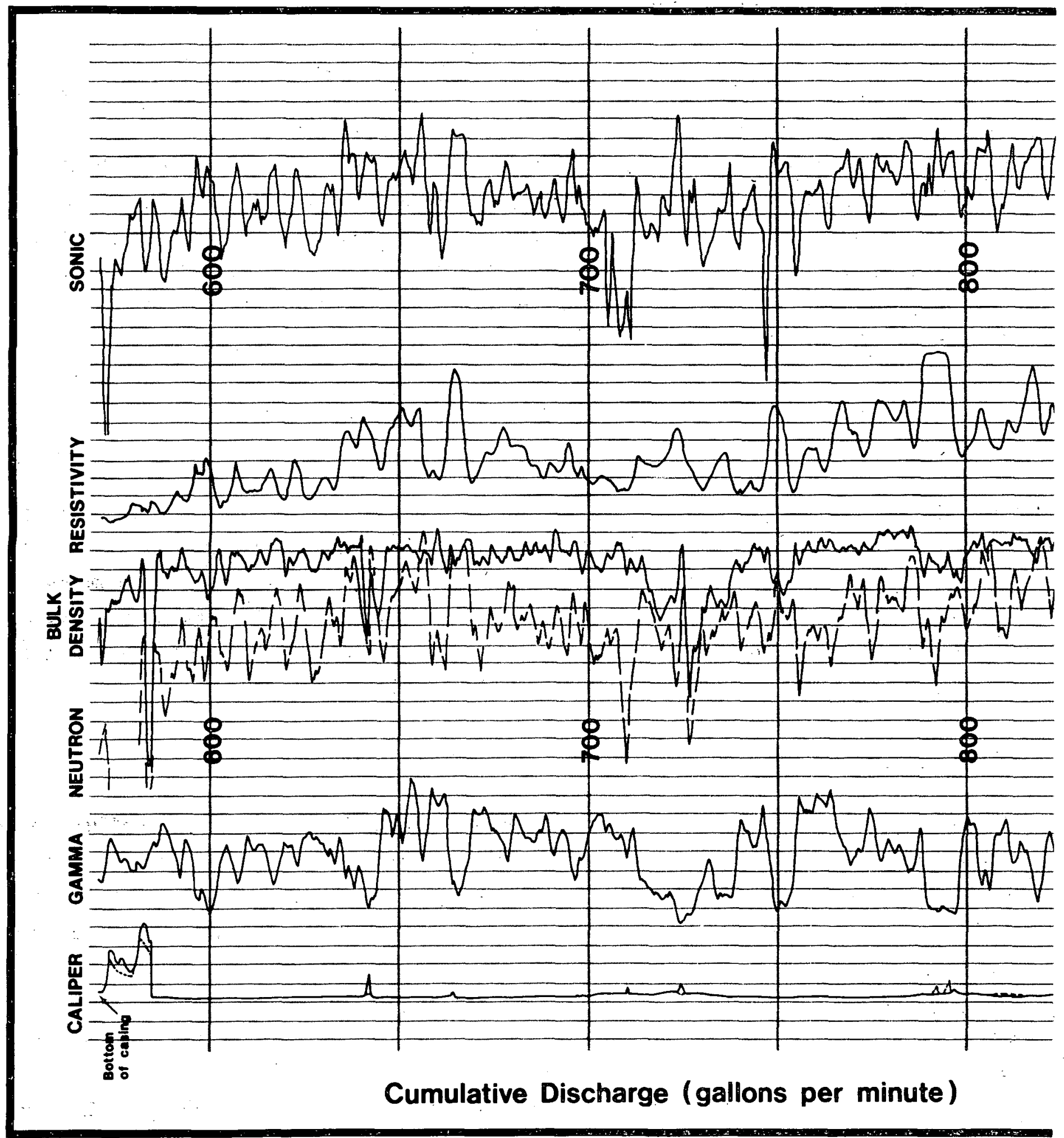




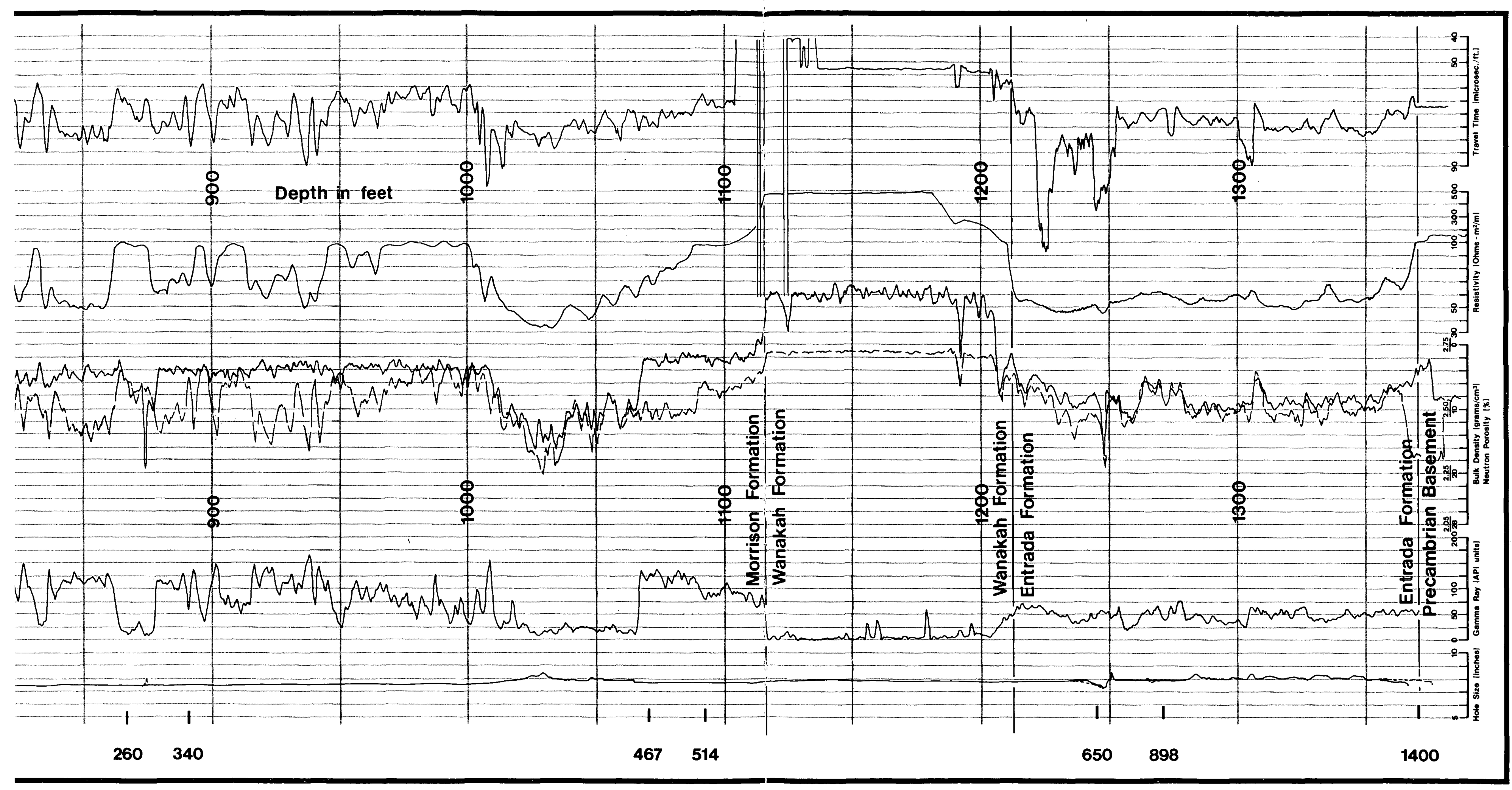

Figure 12 - Geophysical Logs of $P-1$ 
TABLE 10. Calculated Values of Transmissivity and Storativity

\begin{tabular}{|c|c|c|c|c|}
\hline $\begin{array}{lc}\text { Method } & \begin{array}{c}\text { Observation } \\
\text { Hole }\end{array} \\
\text { of Analysis } & \end{array}$ & \multicolumn{2}{|c|}{$\begin{array}{l}\text { Courthouse } \\
\mathrm{T}(\mathrm{gpd} / \mathrm{ft}) \mathrm{s}\end{array}$} & \multicolumn{2}{|c|}{$\begin{array}{c}0-2 \\
T(g p d / f t) S\end{array}$} \\
\hline Aron-Scott & $\begin{array}{l}T_{1}=5400 \\
T_{2}=11,500 \\
T_{3}=24,000\end{array}$ & $\begin{array}{l}S_{1}=.15 \times 10^{-3} \\
S_{2}=63 \times 10^{-3} \\
S^{4}=.3 \times 10^{-3}\end{array}$ & \multirow{4}{*}{55,000} & \multirow{3}{*}{$8.3 \times 10-3$} \\
\hline \multirow[t]{2}{*}{ The is } & $T_{1}=2,400$ & $S_{1}=1.1 \times 10^{-5}$ & & \\
\hline & $T_{2}=8,400$ & $S_{2}=1.3 \times 10^{-7}$ & & \\
\hline Hantush-Jacob & 600 & $8 \times 10-5$ & & \\
\hline
\end{tabular}

TABLE 11. Summary Table of Physical Parameters from 0-2

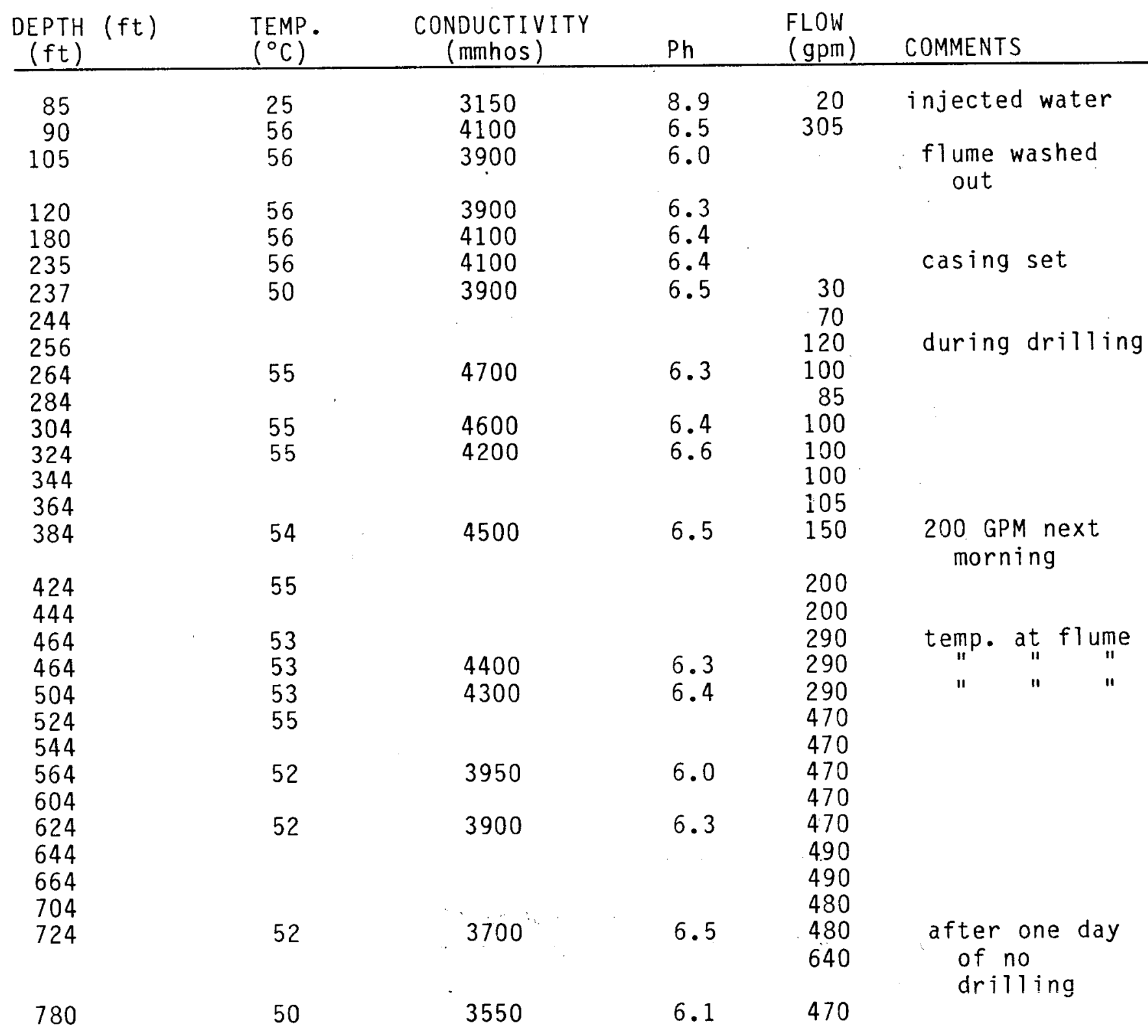




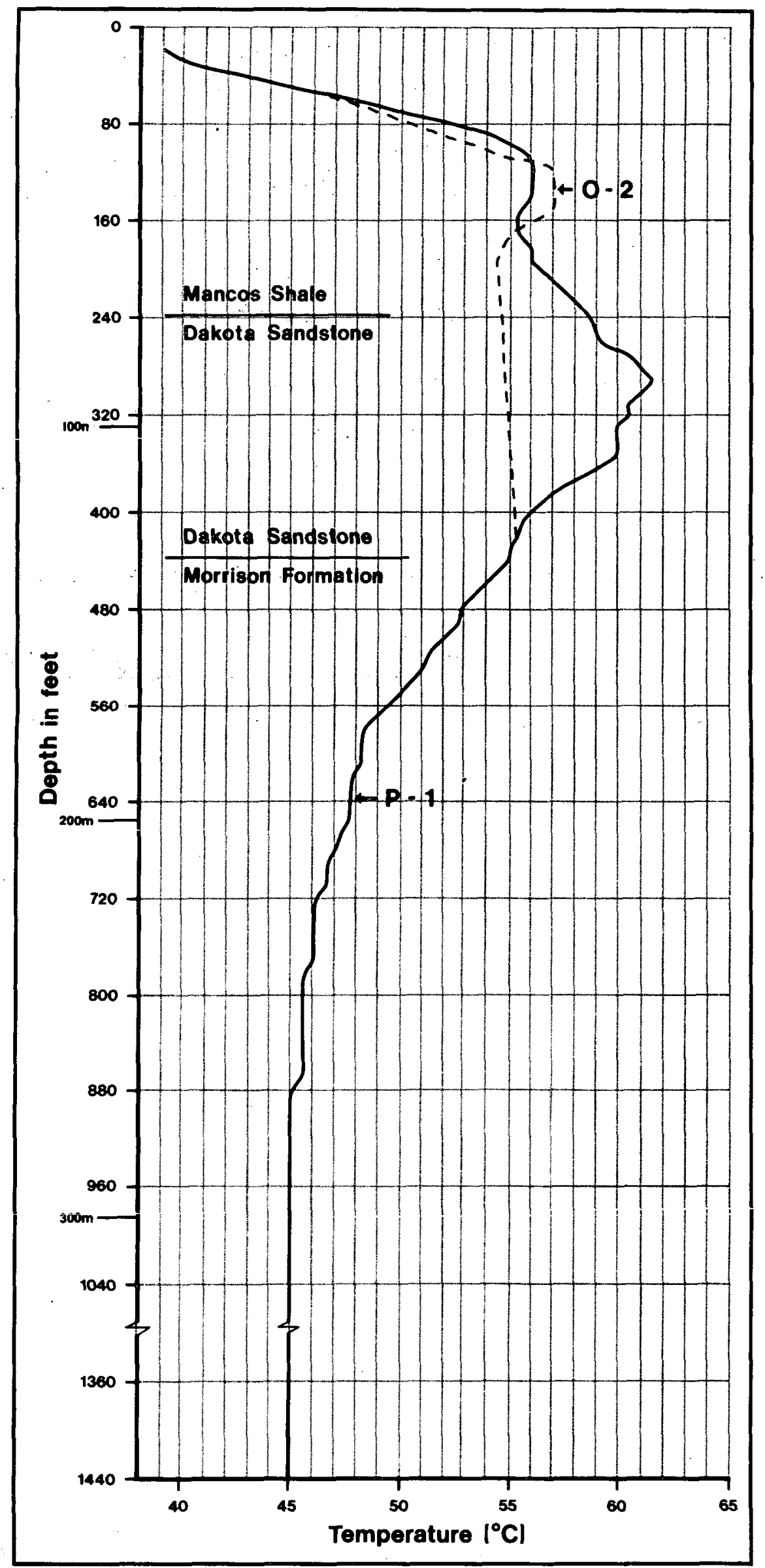

Figure 13 - Temperature Profiles of $P-1$ and $0-2$ 
TABLE 12. Summary Table of Physical Parameters from P-1

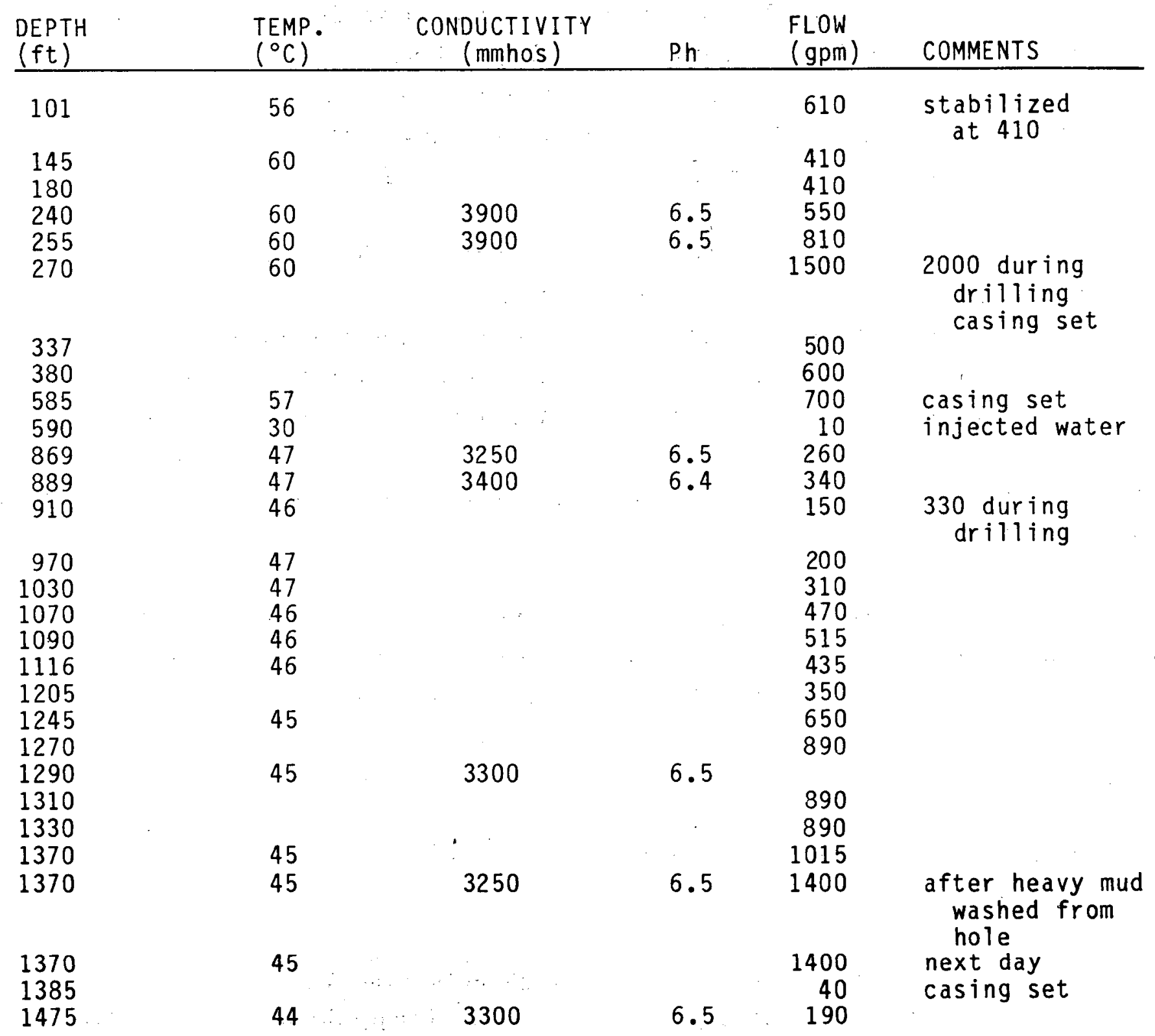


Natural Gamma: The gamma log shows the alternating sandstone, siltstone, shale sequences of the Morrison. Formation (Fig. 12). A section of this curve between 1020 and $1070 \mathrm{ft}(310-325 \mathrm{~m})$ correlates very well with the increasing dolomite content, as described in Table 13. The gamma curve also correlates well with 1 imestone-anhydrite of the Wanakah Formation (Fig. 12).

Neutron/Bulk Density: The alternating nature of the Morrison Formation is depicted by these logs (Fig. 12). The sharp contacts of the Wanakah Formation are also easily seen in those curves. At the base of the Morrison and the contact between the Entrada Formation and the Precambrian basement, these curves show definite porosity increases, which correlate well with producing zones.

Resistivity: The resistivity curve correlates well with the logs discussed above and the 1 ithology.

Sonic: The primary features of this curve are fractures between 1200 and $1250 \mathrm{ft}$ (365-380 m) in the Entrada Formation and the cycle skipping at the top of the Wanakah Formation (Fig. 12). The cycle skipping usually indicates fractures; however, there were no other fracture indicators at this depth. They may be due to the sharp interface between the Morrison and Wanakah Formations.

Quantitative interpretation of these logs was attempted, but the results were inconclusive and will not be reported.

Temperature Logs: Numerous temperature logs were run at various stages of the drilling to delineate producing zones and distinguish between thermal and nonthermal zones. Selected profiles are shown in Figure 13.

The profiles in Figure 13 were run under shut-in conditions after the hole was allowed to stabilize for several weeks.

The P-1 profile shows two distinct thermal zones which correlate with hot water encountered in the Mancos Shale and Dakota Sandstone. The temperature decreases to $45^{\circ} \mathrm{C}$ after reaching a peak of $61^{\circ} \mathrm{C}$ opposite the fault zone in the Dakota Sandstone and becomes isothermal by about $800 \mathrm{ft}(243 \mathrm{~m})$. Isothermal conditions 
continue through the Wanakah and Entrada Formations and into the Precambrian basement. Unfortunately, slight doglegs in the hole at about $1455 \mathrm{ft}$ (442 $\mathrm{m}$ ) prevented temperature measurements to the total depth.

In contrast, the 0-2 profile; taken July 29, 1978, shows only one thermal zone between the surface and $572 \mathrm{ft}(174 \mathrm{~m})$, which is in the Mancos shale at about $85-95 \mathrm{ft}(26-29 \mathrm{~m})$.

\section{Well Pressure Changes During Drilling}

Four-inch 0-60 psi and 0-120 psi Marshalltown pressure gauges were installed on the courthouse well (13 CADC1), Buhlers well (13 CADB1), and 0-2 (while drilling $P-1)$ (Fig. 7). A fourth gauge was used to measure shut-in pressure of $P-1$ whenever possible. A calibrated rod was used to monitor approximate water levels in the main spring vent, $A$.

Although the data were not recorded continuously, the pressure fluctuations give a good indication of the response of various wells and the spring (Fig. 14). As can be seen in Figure 14, Buhler's well and the courthouse well respond rapidly to the opening and closing of the 10-inch gate valve on 0-2; one 12-hour shift was used for drilling, allowing the well to be shut-in for 12 hours.

On August 16, the high flow within the Mancos Shale was encountered at $100 \mathrm{ft}$ (31 $m$ ) in P-1 affecting the pressures on 0-2, Buhler's and the courthouse well (Fig. 14). Pressure in the courthouse well dropped to zero by the $17 \mathrm{th}$. Unfortunately, the gauge on Buhter's well jammed sometime on the 16 th. 0-2 showed minimal pressure drop, from 60 to 52 psi, due to flow from this upper zone, but dropped drastically, to $38 \mathrm{psi}$, when the fault zone at $255 \mathrm{ft}$ (80 m) was encountered. The pressure of the courthouse remained near zero and the spring level dropped $26 \mathrm{in}$. $(22.5 \mathrm{~cm})$, a maximum drop (Fig. 14). The pressure of other wells in town, as far away as $1000 \mathrm{ft}(300 \mathrm{~m})$, also went to zero. The courthouse wel1, 0-2, and the spring level began to recover when the hole was cased, but the pressure of 0-2 dropped to-a minimum of 32 psi as drilling continued in the Dakota Sandstone and the Morrison Formation (Fig. 14). Pressures and the spring level recovered and stabilized after casing was installed, and lower zones were encountered and the drilling continued into the Precambrian basement. 


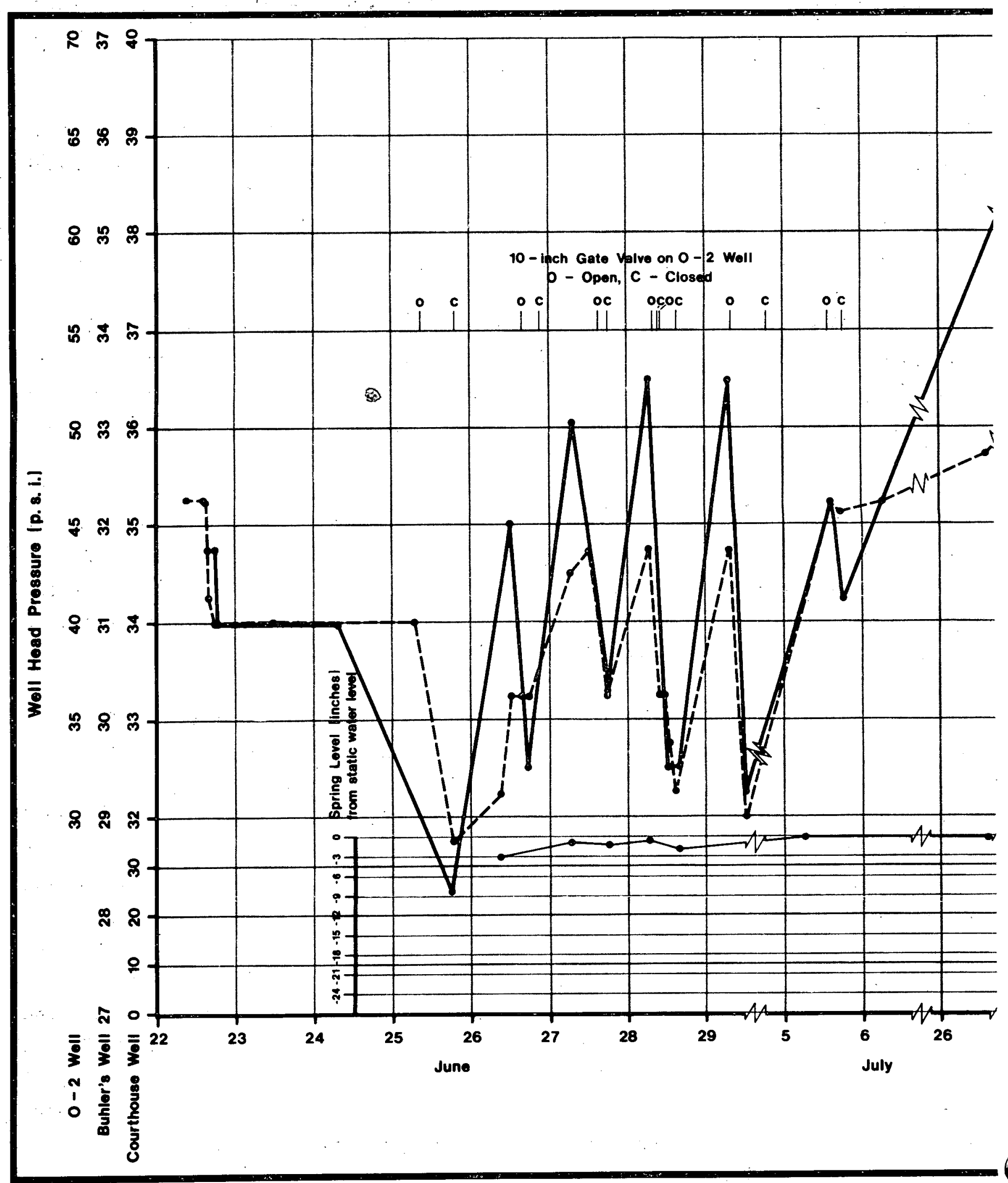

Figure 14 - Hydrographs of Thermal Wells 


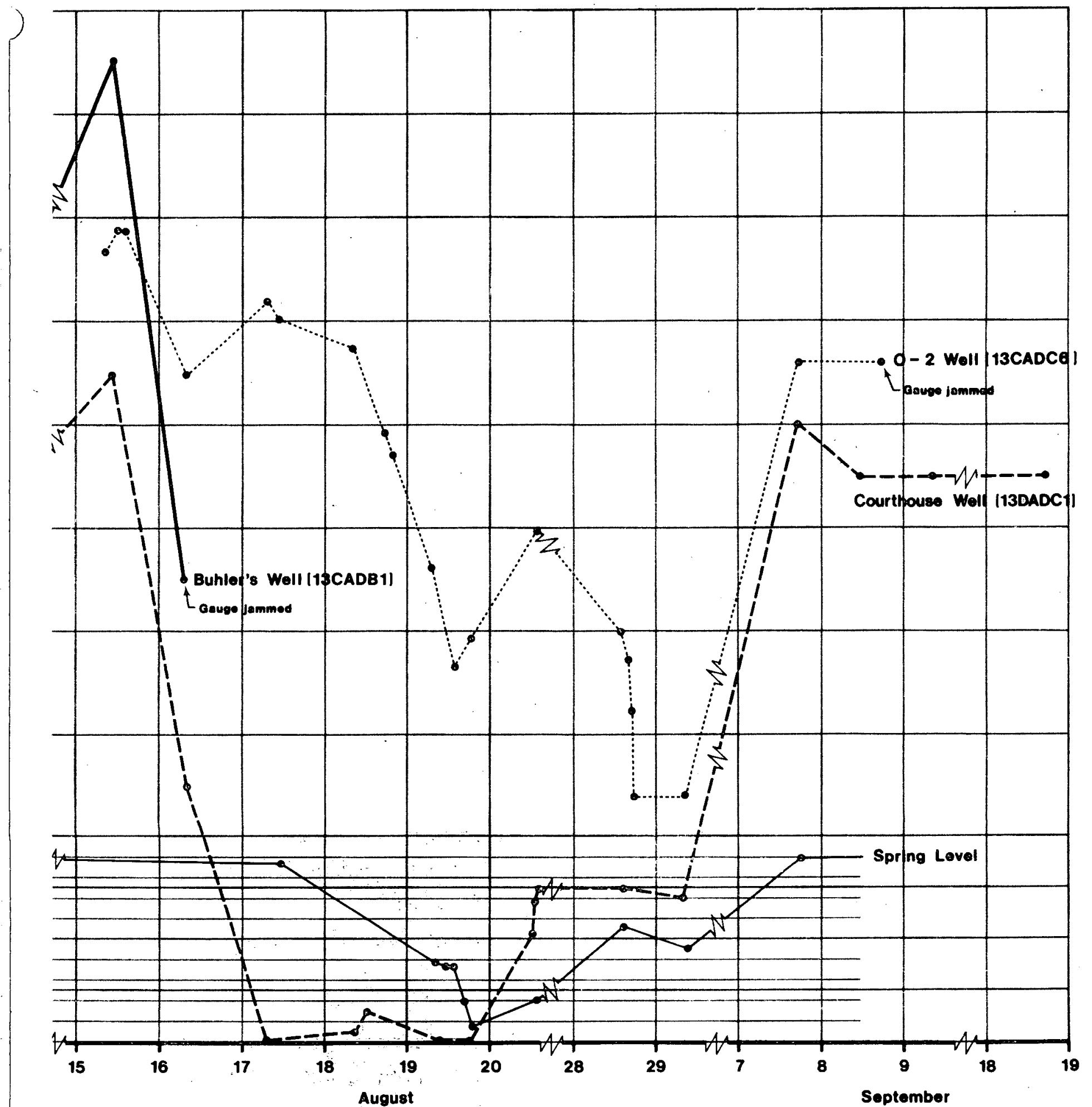

Time [ days |

and Springs, Pagosa Springs, Colorado 
General Nature of the Pagosa Springs Geothermal System

There are no geologic indications of intrusives providing heat to the Pagosa geothermal system. The youngest known intrusives are the latest Miocene dikes of the Archuleta dike swarm and the 26-28 m.y. old subvolcanic batholith postulated by Lipman and others (1978). The lack of adequately young intrusives suggests that heat is provided to the geothermal system by a slightly enhanced regional geothermal gradient.

Assuming a twice normal geothermal gradient of $60^{\circ} \mathrm{C} / \mathrm{km}$ in the Pagosa area (Barrett and others, 1976; and Edwards and others, 1978), meteoric water would have to circulate down 1 to 2 kilometers $(6500 \mathrm{ft})$ to acquire either the observed or calculated temperature. This required depth of circulation suggests that the crystalline rock of the Precambrian basement is the primary geothermal reservoir.

An argument often used against such deep circulation of meteoric water is that fractures close with depth and, therefore, permeabilities and porosities approach zero. However, numerous tunnel, mine, and drilling operations have shown the existence of permeable zones at depths of several thousand meters, most of which are associated with faulting (Davis and Turk, 1964). In one example, Batzle and others (1978) show that porosity increases with depth from $5 \times 10^{-4}$ to $25 \times$ $10^{-4}$ in core from the Marysville, Montana, geothermal test well. Also, they show matrix permeability increases as much as 2 orders of magnitude below 1200 meters. Galloway (1977) postulated that in most cases, deep circulation and subsequent heating requires the intersection of major structures with crystalline rocks, such as batholiths or Precambrian complexes. In the northern Rocky Mountains, hot springs are overwhelmingly associated with crystalline rocks (Galloway, 1977).

The water chemistry, including isotope analyses, support the idea of meteoric water circulation. It is unlikely that water originating within the crystalline rocks would have such high total dissolved solids, particularly high sulfates. Also, it is unlikely that water flowing entirely within the sedimentary units 
would have high lithium, boron, and fluoride, as do these geothermal fluids. The most probable flow regime would include significant contributions of various parameters to meteoric water by both sedimentary and crystalline rocks. The oxygen 18-deuterium ratios also support the idea of a completely meteoric water source.

\section{Description of Circulation System}

One of the major questions regarding the nature of this sytem is whether the thermal water is flowing laterally through the Dakota Sandstone or is fed verticaliy to the Dakota Sandstone by a vertical feature. Information collected during this study supports the latter concept.

The configuration and locations of known hot water wells indicate the lateral extent of the thermal water is limited (Plate 2). Wells which have encountered cold to warm water have been drilled on the periphery of the downtown area. One of these wells (13 CBDC) completely penetrates the Dakota Sandstone. Other wells completed in the Dakota Sandstone in the Pagosa area have encountered cold groundwater.

The two resistivity maps (Figs. 5 and 6 ) mimic the limited area of known hot water. Lateral flows would have been well within the depth range of the dipole-bipole survey and with its contrasting water chemistry, should have been detected.

The pressure response of wells completed in various units and changes in the spring level indicate, a high degree of interconnection between all the units, except the basement rocks (at. least within the time frame of the drilling). However, the potentiometric pressure of the thermal water increases from 35 psi in the Mancos Shale to $85 \mathrm{psi}$ in the Precambrian basement, suggesting this is a discharge area for the thermal water system, which includes all the rock units beneath Pagosa Springs.

The high degree of interconnectivity of the rock units is supported by the thermal water chemistry. Analyses from various wells, springs, and the test holes, from all depths, are very nearly the same (Tables 3,5, and 8). The only difference, 
relative calcium and sodium percentages, shows a linear relationship with respect to depth (Fig. 9) without any significant changes in total dissolved solids, suggesting the waters are the same.

Another strong argument for a system controlled by a vertical feature is the high flow encountered in the Dakota Sandstone in $P-1$, but not in $0-2,93$ feet $(28 \mathrm{~m})$ from $P-1$. The vertical feature encountered in $P-1$ is probably a small displacement vertical fault which may be either the major conduit, as suggested by its strong control over pressures in all thermal wells and springs, or is one of many related, interconnected vertical faults. If this type of fault were to continue well into the basement, it would explain why high, hot flows were not encountered in basement rocks. The high volume, hot water might be restricted to fault zone(s) and mixes with cold groundwater over larger volumes of the aquifers. This is supported by the lack of hydrothermal mineralization and alteration noted in the Precambrian rocks, whereas alteration and mineralization becomes more intense closer to the fault zone at $255 \mathrm{ft}(77 \mathrm{~m})$.

\section{Age of the Thermal System}

No clean-cut answer is available concerning the age of this system. Atkinson suggests a calculable minimum age if erosion data were available, assuming 800-1000 ft (241-301 m) of overburden have been stripped off since the system reached a maximum temperature of about $230^{\circ} \mathrm{C}$. However, a good estimate of erosion rates is not known at this time. 


\title{
MINERALOGICAL AND PETROGRAPHIC INVESTIGATION OF SAMPLES FROM GEOTHERMAL WELLS 0-1 AND P-1, PAGOSA SPRINGS, COLORADO
}

by

\author{
W.W. Atkinson, Jr.
}

Introduction

Samples of cuttings and drill core were subjected to several types of examination: visual study, x-ray diffraction, thin sections and fluid inclusion observations. This work provided information on the nature of the rocks within the geothermal system, as well as on minerals deposited by the system, and temperatures it attained during deposition.

Mr. Paul Boni assisted with the x-ray studies. Mr. Gary Mitch carried out thin section studies on the sedimentary rocks. This assistance is gratefully acknowledged.

\section{Visual Examination}

Each of the 110 samples of cuttings recovered was examined under a binocular microscope. Characteristics of the cuttings such as color, grain size, roundness, sorting and mineral proportions were estimated visually. Samples were washed and examined wet for clarity, and the disintegration of clays in water could be observed. Each sample was tested for calcite with dilute hydrochloric acid. Results of this study are summarized in Table 13. In general, most of the samples appeared to consist primarily of cuttings taken from the sample interval, with only small proportions of caved cuttings from higher in the hole. Where some doubt existed as to the depth of origin, each lithology in a sample and its approximate percentage of cuttings is given.

Eight $\mathrm{ft}$ of core from the bottom of the hole were examined with a hand lens and microscopically. These results are summarized in Table 14. 
Table 13

Visual Descriptions of Well Cuttings

A. Well $0-1$

Depth of samples

(feet)

$0-160$

$241-284$

$299-402$

$419-422$

$459-464$

$479-484$

$499-504$

\section{Description}

Shale, soft, very dark brownish gray, fissile. Locally contains some detrital sand, flakes of biotite. Pyrite in tiny (0.2 mm or less) clusters of cubes at 105 and 120. Shale calcareous at 120, and white calcite veinlets 120 to 160 .

Shale, soft, medium brownish gray, noncalcerous, with sandstone laminate 1-5 mm thick, and beds of unknown thickness. Sandstone is f.g. to m.g., well-sorted, arkosic, and with clots and streaks of carbonaceous matter. Some shale shows slicken-sides.

Hydrothermal euhedral quartz and pyrite crusts up to $1 \mathrm{~mm}$ thick coat many fragments of sandstone and some shale. Barite clots occur with pyrite and euhedral quartz crystals up to $1 \mathrm{~mm}$ long on one fragment. Material for fluid inclusion study came from this interval.

Sandstone, quartzitic, light gray, medium to coarsegrained, slightly arkosic. Sparse carbonaceous and shaly laminations. A little pyrite on fractures 399-402.

Shale, black, with abundant quartz silt and sand.

70\% cuttings caved from above. $30 \%$ sandstone, light greenish gray, very poorly sorted ( 0.1 to $3 \mathrm{~mm}$ ), poorly rounded, frosted grains. Some light brown chalcedony grains. Some white clay clots 2-3 mm. 10-40\%. light greenish clay. Sparse disseminated pyrite cubes.

Shale, medium gray and medium greenish gray, soapy, swells and disintegrates in water. $10-2 \%$ clear quartz sand, poorly sorted, poorly rounded.

A little sandstone, coarse grained (2-3 mm), poorly sorted, poorly rounded, with clay matrix.

Sandstone, white, wel1-rounded, frosted grains 0.3-0.5 $\mathrm{mm}$ in diameter, high porosity. About 10\% very fine grained material between grains.

Common to abundant euhedral pyrite on fracture surfaces. A little euhedral quartz. 
$519-524$

Sandstone, white, well-rounded, frosted grains, mediumto coarse-grained cemented by soft white clay. About $20 \%$ chert pebbles 0.5-2 mm, white, gray, black, red. A little pyrite in clots and single euhedral crystals. on some fragments.

$539-564$

$20 \%$ white sandstone as in previous sample. Shale, light blue-greenish gray, soapy, soft, $10 \%$ very clear quartz sand. Swells in water.

$564-584$

$599-604$

$655-659$

$658-664$

$80 \%$ shale as in previous sample. $5 \%$ shale, dark brownish red, slightly to very silty, swells in water. $15 \%$ caved cuttings from above.

$75 \%$ sandstone, white, medium-grained, we11-rounded, frosted grains, partly cemented by white clay. Abundant open pore spaces containing pyrite crystals. $10 \%$ siltstone, pale green, swells in water. $5 \%$ tiny disseminated euhedral pyrite cubes. $5 \%$ siltstone, dark brownish red argillaceous, and silty shale. Shale swells in water. $10 \%$ caved cuttings from above.

Sandstone, pale yellow, fine-grained, hard, about $30 \%$ clots of interstial white clay, with some bright green clots (possibly celadonite or chlorite).

90\% shale, soft, soapy, pink, dark reddish brown and pale green, with 5\% quartz sand. Some fragments appear to consist of sand-size lithic clasts, probably originally tuffaceous. 10\% 1 imestone, light gray, very fine grained.

B. We11 $P-1$

Depths of samples (feet)

345

$598-601$

$601-608$
Shale, black, carbonaceous, with black waxy partings and lenses up to several $\mathrm{mm}$ thick. Fragments of elongated pyrite concretions up to about $5 \mathrm{~mm}$ diameter, with radial growth patterns.

35\% sandstone, white, well sorted, medium grained. About $40 \%$ clear quartz and $60 \%$ opaque white quartz. Sparse red and green grains, part of which are soft clay. $10 \%$ shale, light blue green, with $10 \%$ clear quartz sand. Disintegrates in water. $5 \%$ caved cuttings from above.

$70 \%$ sandstone, white to pale pink, as in previous sample. Red lithic grains more abundant. $20 \%$ siltstone to shale, medium to dark reddish brown. $10 \%$ lithic sandstone, medium reddish gray, medium grained, with 20 to $40 \%$ clear quartz grains. The remaining grains are white; pink, reddish brown, and rare green lithic fragments well-sorted, and which are partly altered to clay. 
and rare green lithic fragments well-sorted, and which are partly altered to clay.

Sandstone, pale pink to medium reddish brown, with $20-70 \%$ clear quartz grains, and the remainder white, pink and reddish brown lithic grains. Medium-grained, well-sorted, except, for rare black to brown chert pebbles. Many cuttings disintegrate in water. Calcareous cement.

$30 \%$ sandstone, medium pinkish gray, medium-grained, as in previous sample. $20 \%$ sandstone, white, hard, with chalcedonic (?) cement and altered white chalky lithic grains. Similar to white sandstone 598-608. 50\% siltstone, medium dark brownish red. Fairly hard.

$648-718$

Arenaceous to 1 ithic sandstone, pinkish to reddish gray, pale tan, and pale greenish to light green, and white. 10 to $30 \%$ clear quartz sand, average $33 \%$. Remainder consists of white, pale gray, blue-green, red, pink, and black and lithic fragments altered to clay. Calcareous cement is common, sparse calcite veinlets.

728

Sandstone, medium tannish gray, medium-grained, wel1sorted, arkosic with $30-40 \%$ blocky white feldspar grains.

Hydrothermal minerals on fracture surfaces on some cuttings. Euhedral quartz, calcite and two tiny grains positively identified as chalcopyrite.

$738-788$

$798-808$

Lithic arenaceous sandstone, fine- to medium-grained, dominantly light- to medium-bluish-grayish green, with some gray and reddish brown. 10-60\% clear quartz sand, average $33 \%$. Remainder consists of pale to dark green, grayish green, purplish gray, white, red and black lithic grains altered to clay. Slightly to very calcareous. Well sorted.

Sandstone, arkosic, light gray, medium-grained, well-sorted. $30-40 \%$ sericitized feldspar and lithic grains.

Euhedral pyrite on some fracture surfaces. Hydrothermal.

Siltstone, dark-purplish gray with pale green streaks.

828

Sandstone, arkosic light gray, medium-grained. About $20 \%$ feldspar, 5\% multicolored lithic grains.

Siltstone to shale, $80 \%$ dark reddish brown, $20 \% 1$ ight gray. Some finely laminated. Soft, disintegrates in water. 
Lithic sandstone, $40 \%$ purplish gray and $60 \%$ ight gray green, medium-grained, poorly sorted, $20-30 \%$ clear quartz grains, $70-80 \%$ 1 ithic grains partly altered to clay.

Shale, silty, $90 \%$ dark brownish red with $10 \%$ pale greenish gray streaks.

Sandstone, white, medium-grained to fine-grained, hard, glassy. Sparse red, black and greenish grains. $10 \%$ chalky cement and clots (dolomite?). Slightly calcareous.

Shale, sandy, 50\% dark purplish gray, 50\% medium greenish gray, calcareous, about $30-40 \%$ quartz sànd.

Sandstone, medium to light brown, fine-grained, well-sorted, very calcarous, abundant interstitial clày.

928

938

948

$958-968$

$978-1068$

$1078-1108$

$1118-1198$

Shale, dark brownish purple with a few pale green streaks. Calcareous.

Sandstone, light tan to white, medium-grained to finegrained, hard, calcareous, $10 \%$ white chalky grains.

Sandstone, purplish gray, medium-grained, very calcarcous, very clay-rich. Speckled with greenish gray spots, which appear to have been volcaniclastic grains.

Shale, slightly greenish medium to dark gray. Very calcerous. $10 \%$ to $20 \%$ fine quartz sand. Some purplish streaks.

Sandstone, white, fine-grained to medium-grained, poorly sorted, $10-30 \%$ white chalky cement and clots (dolomite?). At 998, very hard. Deeper sandstone is soft and friable or disaggregated. At $1068 \mathrm{ft}$, coarse poikilitic dolomite cements the rock.

Shale, medium- to dark-reddish brown, $10 \%$ silt to sand, slightly to very calcareous. Calcite veiniets present at top.

Limestone-anhydrite. White crystalline anhydrite in nodules 2-5 mm diameter with fetid medium to dark gray, finely crystalline 1 imestone between. Average 40\% anhydrite nodules. 1128-1138, 60-70\% anhydrite.

1208

Limestone, platy, laminated, 1-2 mm, black, with $5 \%$ gypsum nodules. A few coarse (1 cm) selenite (gypsum) cleavage fragments. 
$1218-1368$

Sandstone, light gray, fine-grained to coarse-grained, very poorly sorted, well-rounded, high sphericity, frosted grains, calcareous. Mostly soft to disaggregated. At 1238, rock is pale pink, arkosic, very hard and non-calcareous. At 1218, rock is carbonaceous.

Pyrite as tiny diseminated crystals, interstitial grains and 1-2 mm thick pyrite veinlets from 1288 to 1258 . From 1258 to 1368 , only rare tiny disseminated pyrite crystals.

$1371-1475$

Gneiss, $40 \%$ fine-grained fol jated biotite, $40 \%$ feldspar porphyroblasts $0.5-1 \mathrm{~mm}$, including $10 \%$ pink to orange to red microcitine and $30 \%$ plagioclase, which is locally sericitized. $20 \%$ clear glassy quartz in small grains in biotite. Red aplite at 1390 .

Table 14

Visual Log of Diamond Drill Core from We11 P-1, 1475-1483 Feet

Description

1475-1475.3 Biotite-feldspar gneiss, fine-grained, as in interval 1371-1475.

1475-1477.6 Granite, fine-grained $(0.5-1 \mathrm{~mm})$, weak foliation. About $30 \%$ quartz, $50 \%$ white to red feldspar, $15 \%$ biotite, $5 \%$ epidate.

1477.6-1479 Migmatite, Lenses of pegmatitic orange microcline and quartz in biotite schist and gray granite gneiss.

1479-1483 Biotite gneiss, fine-grained. $80 \%$ biotite and $20 \%$ feldspar grains ( $1 \mathrm{~mm}$ or less) in disseminations and streaks in biotite. 
X-Ray Diffraction Study

Seventy-nine of the samples were subjected to an x-ray diffraction examination. Representative portions of the cuttings were crushed to pass 200 mesh and loaded into an aluminum sample holder to obtain a sample approximately $\underline{1} \times \underline{2} \mathrm{~cm} \times \underline{2} \mathrm{~mm}$ thick. The samples were then run on a Norelco diffractometer. The following operating conditions were used: Cu radiation, $35 \mathrm{kV}, 17 \mathrm{ma}$, scan $2^{\circ}$ per minute, chart speed $1 / 2$ in. per minute.

Charts of samples were compared with charts of standards for identification, which were compared with powder patterns listed in the ASTM X-ray Diffraction card file, to ensure that no extraneous peaks were present. All peaks could be identified from rocks in the sedimentary section. In the Precambrian rocks at the bottom of the hole, a few very minor peaks defied identification. In order to identify such minor components, other methods such as thin section studies are necessary. This is because the complex pattern of peaks from the five or more major minerals effectively masks most of the pattern of a minor constituent.

Results are summarized in Table 15. Only minerals which were postively identified are listed. Three categories of concentration are given: major, moderate to minor, and trace. Due to the characteristics of each mineral, these relative proportions are only very approximate. Proportions of clays in particular are difficult to estimate from diffractometer charts, since a poorly crystallized clay may show very low peaks even when pure. Some minerals, such as feldspars, have major peaks which are masked by quartz. When potassium feldspars are minor constituents, not enough of their patterns are visible to discriminate between orthoclase and microcline. Consequently, only "K-feldspar" was reported. Albite, on the other hand, can be easily distinguished. With the complex mixtures of patterns obtained, micas cannot be discriminated. Since biotite was visible in the samples at the bottom of the hole, peaks for mica were taken to indicate biotite. However, muscovite in addition was seen in the thin sections.

Clay minerals were given special attention. Illite is indicated in a large number of samples by a peak near 10A (angstroms). This peak varies considerably in quality, from a somewhat broad hump, to a fairly narrow one. Its intensity was 
usually less than $10 \%$ full scale deflection, although in a few samples it ranged up to $25 \%$. In a few samples a faint rise at $14 \mathrm{~A}$ indicates the presence of montmorillonite. Kaolinite was indicated by a fairly sharp peak at 7A, although the quantity present was usually small. Chlorite occurs in the Precambrian rocks. It has a very poor $14 \mathrm{~A}$ peak, with a sharp, much higher $7 \mathrm{~A}$ peak.

Thirteen samples were selected for glycolation and heating tests. In one, (0-1, 479-484), the montmorillonite peak clearly shifted from 14A to $17 \mathrm{~A}$. In other samples, the montmorillonite concentration was too low to observe peak shifts. The illite peaks did not shift, but dropped slightly in intensity and sharped somewhat. This suggests the presence of small concentrations of randomly interlayered montmorillonite. Glycolation did not affect 7 A peaks for kaolinite. Heating to $550^{\circ} \mathrm{C}$ sharpened $i 11$ ite peaks and caused montmorillonite and kaolinite peaks to disappear. These tests, which are standard for clay minerals, provide support for the identifications of patterns on other charts.

\section{Fluid Inclusion Study}

In several samples, euhedral quartz and pyrite were observed on fracture surfaces. These minerals have an appearance typical of crystals deposited by hydrothermal fluids. Other minerals observed locally included calcite, barite and chalcopyrite.

Several rock fragments were recovered from $248 \mathrm{ft}$ depth in well P-1. They were coated wtih drusy, euhedral quartz and pyrite, and one fragment had barite as well. The thickness of the quartz crust was about $1 \mathrm{~mm}$ or less. Two of the cobbles were selected for fluid inclusion study. Thin slices were cut, then ground on both sides to a thickness of 0.2 to $0.4 \mathrm{~mm}$, polished on both sides, then carefully examined by microscope for fluid inclusions.

The hydrothermal quartz is remarkably clear, and free of fluid inclusions. After an extensive search, only three were found which were large enough, about 10 to 15 microns in diameter, for determination of filling temperatures. A number of others (13) were found which could be measured roughly, and from which estimates of the ratio of volume of the bubble to volume of the incusion were made. This 
type of estimate yields rough figures, which are subject to errors. The main source of error arises from the fact that the three-dimensional shape of the entire inclusion cannot be seen. Usually, the inclusion is assumed to have a square or circular cross-section normal to the plane of the polished surface. If the inclusion is actually larger, the true bubble to inclusion ratio is smaller, and the estimated temperature of filling is too high. With these limitations in mind, volume ratios of bubble to entire inclusion were found to range from 0.021 to 0.18 . Assuming that the liquid is pure water, these inclusions would fill at temperatures from 71 to $232^{\circ} \mathrm{C}$. One inclusion which had a long tube-shaped form could be fairly accurately measured. It yielded an estimate of $198^{\circ} \mathrm{C}$.

Filling temperatures of fluid inclusions were measured on a Chaix-Meca (Nancy, France) heating stage. The apparatus was calibrated with substances with known melting points. The calibration runs suggest an accuracy of $\pm 1^{\circ} \mathrm{C}$.

Before filling temperatures were measured in hydrothermal quartz, two inclusions in heated fractures in sandstone grains were studied. The first filled at $171.2^{\circ} \mathrm{C}$, with a precision of $\pm 1.0^{\circ} \mathrm{C}$, using four measurements. The second filled at $161.8^{\circ} \mathrm{C}$. Oniy one measurement was made.

Of the three inclusions in a hydrothermal quartz crystal, one leaked at $184^{\circ} \mathrm{C}$. The second filled at $252.1^{\circ} \mathrm{C}$. When an attempt was made to repeat the measurement, it, too, leaked. A third inclusion filled at $230.5^{\circ} \mathrm{C}$. This was the lowest of four repeats, which gave results in sequence of $231.5,234.5,230.5$, and 231.5 . The second of the group appeared to be in error due to a poor observation. Another six measurements were made, which gave the following results in sequence: $236.5,237.5,236.5,239.2$, and 240.2. These results are significantly higher than the first four, and appeared to be systematically increasing with each cycle of heating and cooling. A leak was therefore suspected, and the first four measurements are probably the only valid ones.

The range of temperatures probably reflect different stages of development in the hot spring system. The heating measurements actually show fairly good agreement with the measurements of inclusion and bubble sizes, and subsequent estimated filling temperatures. 
TABLE 15

Mineralogy of $0-1$ and P-1 Wel1 Cuttings Determined by X-ray niffractometer

\begin{tabular}{|c|c|c|c|c|c|c|c|c|c|}
\hline Sample & quartz & illite & calcite & dolomite & albite & $\begin{array}{l}\text { K-feld- } \\
\text { spar }\end{array}$ & $\begin{array}{l}\text { Kao- } \\
\text { linite }\end{array}$ & pyrite & other \\
\hline \multicolumn{10}{|l|}{ WELL $0-1$} \\
\hline $\begin{array}{c}100 \\
105 \\
120 \\
140-160 \\
241-244\end{array}$ & $\begin{array}{l}x \\
x \\
x \\
x \\
x\end{array}$ & $\begin{array}{l}x \\
x \\
x \\
x \\
x\end{array}$ & $\begin{array}{l}x \\
x \\
x \\
x\end{array}$ & $\begin{array}{l}\operatorname{tr} \\
x\end{array}$ & $\begin{array}{l}x \\
t r\end{array}$ & tr & $\begin{array}{l}x \\
x \\
x \\
x\end{array}$ & $\begin{array}{l}x \\
x \\
x\end{array}$ & $\begin{array}{l}\text { tr. mont. } \\
\text { tr. mont. } \\
\text { tr. mont. } \\
\times \text { mont. }\end{array}$ \\
\hline $\begin{array}{c}264 \\
284 \\
299-304 \\
319-322 \\
339-342\end{array}$ & $\begin{array}{l}x \\
x \\
x \\
x \\
x\end{array}$ & $\begin{array}{l}x \\
x \\
\operatorname{tr} \\
x \\
\operatorname{tr}\end{array}$ & - & $x$ & & & . & $x$ & tr. mont. \\
\hline $\begin{array}{l}399-402 \\
419-422 \\
459-464 \\
479-484 \\
499-504\end{array}$ & $\begin{array}{l}x \\
x \\
x \\
x \\
x\end{array}$ & $\begin{array}{l}x \\
x \\
x \\
x \\
x\end{array}$ & ' & & & & $x$ & $\begin{array}{l}\operatorname{tr} \\
\operatorname{tr}\end{array}$ & tr. mont. \\
\hline $\begin{array}{l}519-524 \\
539-564 \\
579-584 \\
599-604 \\
655-659\end{array}$ & $\begin{array}{l}x \\
x \\
x \\
x \\
x\end{array}$ & $\begin{array}{l}x \\
x \\
x \\
x \\
x\end{array}$ & & $x$ & tr & & $x$ & $\begin{array}{l}\operatorname{tr} \\
\operatorname{tr} \\
\operatorname{tr} \\
x\end{array}$ & \\
\hline $658-664$ & $x$ & $x$ & $\operatorname{tr}$ & $x$ & tr & & $\operatorname{tr}$ & $\operatorname{tr}$ & \\
\hline \multicolumn{10}{|l|}{ WELL P-1 } \\
\hline $\begin{array}{c}248-268 \\
345 \\
598-601 \\
668 \\
678\end{array}$ & $\begin{array}{l}x \\
x \\
x \\
x\end{array}$ & $\begin{array}{l}\operatorname{tr} \\
x \\
\operatorname{tr} \\
x \\
\end{array}$ & $\begin{array}{l}\operatorname{tr} \\
\operatorname{tr}\end{array}$ & $\begin{array}{l}x \\
x \\
x\end{array}$ & $\begin{array}{l}x \\
x \\
t r\end{array}$ & & $\begin{array}{l}x \\
x\end{array}$ & & $\begin{array}{l}\text { barite } \\
\text { tr. mont. }\end{array}$ \\
\hline $\begin{array}{l}688 \\
708 \\
718 \\
728 \\
738\end{array}$ & $\begin{array}{l}x \\
x \\
x \\
x \\
x\end{array}$ & $\begin{array}{l}x \\
x \\
x \\
t r\end{array}$ & $\begin{array}{l}x \\
x \\
\text { tr }\end{array}$ & $\begin{array}{l}x \\
x \\
x \\
x \\
x\end{array}$ & $\begin{array}{l}x \\
\operatorname{tr} \\
x \\
x \\
x\end{array}$ & & $\begin{array}{l}\mathrm{tr} \\
\mathrm{tr}\end{array}$ & & \\
\hline $\begin{array}{l}748 \\
758 \\
768 \\
778 \\
788\end{array}$ & $\begin{array}{l}x \\
x \\
x \\
x \\
x\end{array}$ & $\begin{array}{l}x \\
x \\
x \\
x \\
x\end{array}$ & $\begin{array}{l}\mathrm{tr} \\
\mathrm{x} \\
\mathrm{x}\end{array}$ & $\begin{array}{l}x \\
x \\
x \\
x \\
x\end{array}$ & $\begin{array}{l}\operatorname{tr} \\
\operatorname{tr} \\
\operatorname{tr} \\
x\end{array}$ & $\begin{array}{l}\operatorname{tr} \\
\operatorname{tr} \\
\operatorname{tr} \\
x\end{array}$ & $\begin{array}{l}\mathrm{tr} \\
\mathrm{tr} \\
\mathrm{tr}\end{array}$ & $\operatorname{tr}$ & . \\
\hline $\begin{array}{l}798 \\
808 \\
818 \\
828 \\
838\end{array}$ & $\begin{array}{l}x \\
x \\
x \\
x \\
x\end{array}$ & $\begin{array}{l}x \\
\operatorname{tr} \\
x \\
\operatorname{tr} \\
x\end{array}$ & $\begin{array}{l}\operatorname{tr} \\
x \\
x \\
t r\end{array}$ & $\begin{array}{l}x \\
x \\
x \\
x \\
t r\end{array}$ & $\begin{array}{l}x \\
\operatorname{tr} \\
x \\
x\end{array}$ & $\begin{array}{l}x \\
\operatorname{tr} \\
x \\
x\end{array}$ & & $\operatorname{tr}$ & \\
\hline
\end{tabular}

WELL P-1

248-268

345

598-601

668

678

688

.708

718

728

738

\begin{tabular}{l}
798 \\
808 \\
818 \\
828 \\
838 \\
\hline 848 \\
858 \\
868 \\
878 \\
888
\end{tabular}

$\begin{array}{lll}\mathrm{x} & \mathrm{x} & \mathrm{tr} \\ \mathrm{x} & \mathrm{x} & \mathrm{x} \\ \mathrm{x} & \mathrm{x} & \mathrm{x} \\ \mathrm{x} & \mathrm{x} & \mathrm{x} \\ \mathrm{x} & \mathrm{x} & \mathrm{x} \\ \mathrm{x}\end{array}$

\begin{tabular}{|c|c|c|c|c|c|c|c|c|c|}
\hline \multicolumn{10}{|c|}{ WELL $0-1$} \\
\hline $\begin{array}{c}100 \\
105 \\
120 \\
140-160 \\
241-244\end{array}$ & $\begin{array}{l}x \\
x \\
x \\
x \\
x\end{array}$ & $\begin{array}{l}x \\
x \\
x \\
x \\
x\end{array}$ & $\begin{array}{l}x \\
x \\
x \\
x\end{array}$ & $\begin{array}{l}\operatorname{tr} \\
\mathrm{x}\end{array}$ & $\begin{array}{l}x \\
t r\end{array}$ & $\operatorname{tr}$ & $\begin{array}{l}x \\
x \\
x \\
x\end{array}$ & $\begin{array}{l}x \\
x \\
x\end{array}$ & $\begin{array}{l}\text { tr. mont. } \\
\text { tr. mont. } \\
\text { tr. mont. } \\
x \text { mont. }\end{array}$ \\
\hline $\begin{array}{c}264 \\
284 \\
299-304 \\
319-322 \\
339-342\end{array}$ & $\begin{array}{l}x \\
x \\
x \\
x \\
x\end{array}$ & $\begin{array}{l}x \\
x \\
\text { tr } \\
x \\
\text { tr }\end{array}$ & & $x$ & & & . & $x$ & tr. mont. \\
\hline $\begin{array}{l}399-402 \\
419-422 \\
459-464 \\
479-484 \\
499-504\end{array}$ & $\begin{array}{l}x \\
x \\
x \\
x \\
x\end{array}$ & $\begin{array}{l}x \\
x \\
x \\
x \\
x\end{array}$ & $\cdot$ & & & & $x$ & $\begin{array}{l}\operatorname{tr} \\
\mathrm{tr}\end{array}$ & tr. mont. \\
\hline $\begin{array}{l}519-524 \\
539-564 \\
579-584 \\
599-604 \\
655-659\end{array}$ & $\begin{array}{l}x \\
x \\
x \\
x \\
x\end{array}$ & $\begin{array}{l}x \\
x \\
x \\
x \\
x\end{array}$ & & $x$ & $\operatorname{tr}$ & & $x$ & $\begin{array}{l}\operatorname{tr} \\
\operatorname{tr} \\
\operatorname{tr} \\
x\end{array}$ & \\
\hline $658-664$ & $x$ & $x$ & $\operatorname{tr}$ & $x$ & $\operatorname{tr}$ & & $\operatorname{tr}$ & $\operatorname{tr}$ & \\
\hline \multicolumn{10}{|l|}{ WELL P-1 } \\
\hline $\begin{array}{c}248-268 \\
345 \\
598-601 \\
668 \\
678\end{array}$ & $\begin{array}{l}x \\
x \\
x \\
x\end{array}$ & $\begin{array}{l}\operatorname{tr} \\
x \\
\operatorname{tr} \\
x \\
\end{array}$ & $\begin{array}{l}\text { tr } \\
\text { tr }\end{array}$ & $\begin{array}{l}x \\
x \\
x \\
\end{array}$ & $\begin{array}{l}x \\
x \\
\text { tr } \\
\end{array}$ & & $\begin{array}{l}x \\
x\end{array}$ & & $\begin{array}{l}\text { barite } \\
\text { tr. mont. }\end{array}$ \\
\hline $\begin{array}{l}688 \\
708 \\
718 \\
728 \\
738\end{array}$ & $\begin{array}{l}x \\
x \\
x \\
x \\
x\end{array}$ & $\begin{array}{l}x \\
x \\
x \\
\text { tr }\end{array}$ & $\begin{array}{l}x \\
x\end{array}$ & $\begin{array}{l}x \\
x \\
x \\
x \\
x\end{array}$ & $\begin{array}{l}x \\
t r \\
x \\
x \\
x\end{array}$ & & $\begin{array}{l}\mathrm{tr} \\
\mathrm{tr}\end{array}$ & & \\
\hline $\begin{array}{l}748 \\
758 \\
768 \\
778 \\
788\end{array}$ & $\begin{array}{l}x \\
x \\
x \\
x \\
x\end{array}$ & $\begin{array}{l}x \\
x \\
x \\
x \\
x\end{array}$ & $\begin{array}{l}\mathrm{tr} \\
\mathrm{x} \\
\mathrm{x}\end{array}$ & $\begin{array}{l}x \\
x \\
x \\
x \\
x\end{array}$ & $\begin{array}{l}\operatorname{tr} \\
\operatorname{tr} \\
\operatorname{tr} \\
x\end{array}$ & $\begin{array}{l}\text { tr } \\
\text { tr } \\
\text { tr } \\
x\end{array}$ & $\begin{array}{l}\operatorname{tr} \\
\operatorname{tr} \\
\mathrm{tr}\end{array}$ & $\operatorname{tr}$ & . \\
\hline $\begin{array}{l}798 \\
808 \\
818 \\
828 \\
838\end{array}$ & $\begin{array}{l}x \\
x \\
x \\
x \\
x\end{array}$ & $\begin{array}{l}x \\
\operatorname{tr} \\
x \\
\operatorname{tr} \\
x\end{array}$ & $\begin{array}{l}\operatorname{tr} \\
x \\
x \\
t r\end{array}$ & $\begin{array}{l}x \\
x \\
x \\
x \\
t r\end{array}$ & $\begin{array}{l}x \\
\operatorname{tr} \\
x \\
x\end{array}$ & $\begin{array}{l}x \\
\operatorname{tr} \\
x \\
x\end{array}$ & & $\operatorname{tr}$ & \\
\hline
\end{tabular}

\begin{tabular}{|c|c|c|c|c|c|c|c|c|}
\hline$x$ & $x$ & $x$ & & & \multirow{5}{*}{$\operatorname{tr}$} & $x$ & $x$ & \multirow{5}{*}{$\begin{array}{l}\text { tr. mont. } \\
\text { tr. mont. } \\
\text { tr. mont. } \\
x \text { mont. }\end{array}$} \\
\hline$x$ & $x$ & $x$ & & \multirow{4}{*}{$\begin{array}{l}x \\
\text { tr }\end{array}$} & & $x$ & $x$ & \\
\hline$x$ & $x$ & $x$ & tr & & & $x$ & & \\
\hline$x$ & $x$ & $x$ & $\mathrm{x}$ & & & $x$ & $x$ & \\
\hline$x$ & $x$ & & & & & & & \\
\hline$x$ & $x$ & & & & & & & \\
\hline$x$ & $x$ & & $x$ & & & & $x$ & tr. mont. \\
\hline$x$ & $\operatorname{tr}$ & & & & & v & & \\
\hline$x$ & $x$ & & & & & & & \\
\hline$x$ & $\operatorname{tr}$ & & & & & & & \\
\hline$x$ & $x$ & . & & & & & $\operatorname{tr}$ & \\
\hline$x$ & $x$ & & & & & $x$ & & \\
\hline$x$ & $x$ & & & & & & & \\
\hline$x$ & $x$ & & & & & & & tr. mont. \\
\hline$x$ & $x$ & & & & & & $\operatorname{tr}$ & \\
\hline$x$ & $x$ & & & & & & $\operatorname{tr}$ & \\
\hline$x$ & $x$ & & & & & & $\operatorname{tr}$ & \\
\hline$x$ & $x$ & & & & & & $\operatorname{tr}$ & \\
\hline$x$ & $x$ & & & & & & $x$ & \\
\hline$x$ & $x$ & & $x$ & $\operatorname{tr}$ & & $x$ & & \\
\hline$x$ & $x$ & tr & $x$ & $\operatorname{tr}$ & & $\operatorname{tr}$ & $\operatorname{tr}$ & \\
\hline & & & & & & & & barite \\
\hline$x$ & $\operatorname{tr}$ & & & & & $x$ & & \\
\hline$x$ & $x$ & & $x$ & $x$ & & $x$ & & \\
\hline$x$ & $\operatorname{tr}$ & $\operatorname{tr}$ & $x$ & $x$ & & & & tr. mont. \\
\hline$x$ & $x$ & $\operatorname{tr}$ & $x$ & tr & & & & \\
\hline$x$ & $x$ & $x$ & $x$ & $x$ & & & & \\
\hline$x$ & $x$ & $x$ & $x$ & $\operatorname{tr}$ & & & & \\
\hline$x$ & $x$ & & $x$ & $x$ & & $\operatorname{tr}$ & & \\
\hline$x$ & $\operatorname{tr}$ & & $x$ & $x$ & & & & \\
\hline$x$ & & $\operatorname{tr}$ & $x$ & $x$ & & $\operatorname{tr}$ & & \\
\hline$x$ & $x$ & $\operatorname{tr}$ & $x$ & $\operatorname{tr}$ & $\operatorname{tr}$ & $\operatorname{tr}$ & & . \\
\hline$x$ & $x$ & & $x$ & & $\operatorname{tr}$ & & & 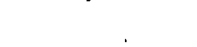 \\
\hline$x$ & $x$ & $x$ & $x$ & $\operatorname{tr}$ & & $\operatorname{tr}$ & & \\
\hline$x$ & $x$ & $x$ & $x$ & $\operatorname{tr}$ & $\operatorname{tr}$ & & $\operatorname{tr}$ & \\
\hline$x$ & $x$ & & $x$ & $x$ & $x$ & $\operatorname{tr}$ & & \\
\hline$x$ & $x$ & $\operatorname{tr}$ & $x$ & & & & & \\
\hline$x$ & $\operatorname{tr}$ & $x$ & $x$ & $x$ & $x$ & & & \\
\hline$x$ & $x$ & $x$ & $x$ & $\operatorname{tr}$ & $\operatorname{tr}$ & & & \\
\hline$x$ & $\operatorname{tr}$ & $\operatorname{tr}$ & $x$ & $x$ & $x$ & & & \\
\hline$x$ & $x$ & & $\operatorname{tr}$ & $x$ & $x$ & & $\operatorname{tr}$ & \\
\hline
\end{tabular}

\begin{tabular}{|c|c|c|c|c|c|c|c|c|}
\hline$x$ & $x$ & $x$ & & & \multirow{5}{*}{$\operatorname{tr}$} & $x$ & $x$ & \multirow{5}{*}{$\begin{array}{l}\text { tr. mont. } \\
\text { tr. mont. } \\
\text { tr. mont. } \\
x \text { mont. }\end{array}$} \\
\hline$x$ & $x$ & $x$ & & \multirow{4}{*}{$\begin{array}{l}x \\
\text { tr }\end{array}$} & & $x$ & $x$ & \\
\hline$x$ & $x$ & $x$ & tr & & & $x$ & & \\
\hline$x$ & $x$ & $x$ & $\mathrm{x}$ & & & $x$ & $x$ & \\
\hline$x$ & $x$ & & & & & & & \\
\hline$x$ & $x$ & & & & & & & \\
\hline$x$ & $x$ & & $x$ & & & & $x$ & tr. mont. \\
\hline$x$ & $\operatorname{tr}$ & & & & & v & & \\
\hline$x$ & $x$ & & & & & & & \\
\hline$x$ & $\operatorname{tr}$ & & & & & & & \\
\hline$x$ & $x$ & . & & & & & $\operatorname{tr}$ & \\
\hline$x$ & $x$ & & & & & $x$ & & \\
\hline$x$ & $x$ & & & & & & & \\
\hline$x$ & $x$ & & & & & & & tr. mont. \\
\hline$x$ & $x$ & & & & & & $\operatorname{tr}$ & \\
\hline$x$ & $x$ & & & & & & $\operatorname{tr}$ & \\
\hline$x$ & $x$ & & & & & & $\operatorname{tr}$ & \\
\hline$x$ & $x$ & & & & & & $\operatorname{tr}$ & \\
\hline$x$ & $x$ & & & & & & $x$ & \\
\hline$x$ & $x$ & & $x$ & $\operatorname{tr}$ & & $x$ & & \\
\hline$x$ & $x$ & tr & $x$ & $\operatorname{tr}$ & & $\operatorname{tr}$ & $\operatorname{tr}$ & \\
\hline & & & & & & & & barite \\
\hline$x$ & $\operatorname{tr}$ & & & & & $x$ & & \\
\hline$x$ & $x$ & & $x$ & $x$ & & $x$ & & \\
\hline$x$ & $\operatorname{tr}$ & $\operatorname{tr}$ & $x$ & $x$ & & & & tr. mont. \\
\hline$x$ & $x$ & $\operatorname{tr}$ & $x$ & tr & & & & \\
\hline$x$ & $x$ & $x$ & $x$ & $x$ & & & & \\
\hline$x$ & $x$ & $x$ & $x$ & $\operatorname{tr}$ & & & & \\
\hline$x$ & $x$ & & $x$ & $x$ & & $\operatorname{tr}$ & & \\
\hline$x$ & $\operatorname{tr}$ & & $x$ & $x$ & & & & \\
\hline$x$ & & $\operatorname{tr}$ & $x$ & $x$ & & $\operatorname{tr}$ & & \\
\hline$x$ & $x$ & $\operatorname{tr}$ & $x$ & $\operatorname{tr}$ & $\operatorname{tr}$ & $\operatorname{tr}$ & & . \\
\hline$x$ & $x$ & & $x$ & & $\operatorname{tr}$ & & & 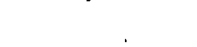 \\
\hline$x$ & $x$ & $x$ & $x$ & $\operatorname{tr}$ & & $\operatorname{tr}$ & & \\
\hline$x$ & $x$ & $x$ & $x$ & $\operatorname{tr}$ & $\operatorname{tr}$ & & $\operatorname{tr}$ & \\
\hline$x$ & $x$ & & $x$ & $x$ & $x$ & $\operatorname{tr}$ & & \\
\hline$x$ & $x$ & $\operatorname{tr}$ & $x$ & & & & & \\
\hline$x$ & $\operatorname{tr}$ & $x$ & $x$ & $x$ & $x$ & & & \\
\hline$x$ & $x$ & $x$ & $x$ & $\operatorname{tr}$ & $\operatorname{tr}$ & & & \\
\hline$x$ & $\operatorname{tr}$ & $\operatorname{tr}$ & $x$ & $x$ & $x$ & & & \\
\hline$x$ & $x$ & & $\operatorname{tr}$ & $x$ & $x$ & & $\operatorname{tr}$ & \\
\hline
\end{tabular}

\begin{tabular}{|c|c|c|c|c|c|c|c|c|}
\hline$x$ & $x$ & $x$ & & & & $x$ & $x$ & tr. mont. \\
\hline$x$ & $x$ & $x$ & & & & $x$ & $x$ & tr. mont. \\
\hline$x$ & $x$ & $x$ & tr & $x$ & tr & $x$ & & tr. mont. \\
\hline$x$ & $x$ & $x$ & $x$ & $\operatorname{tr}$ & & $x$ & $x$ & $x$ mont. \\
\hline$x$ & $x$ & & & & & & & \\
\hline$x$ & $x$ & & & & & & & \\
\hline$x$ & $x$ & & $x$ & & & & $x$ & tr. mont. \\
\hline$x$ & tr & & & & & - & & \\
\hline$x$ & $x$ & & & & & & & \\
\hline$x$ & $\operatorname{tr}$ & & & & & & & \\
\hline$x$ & $x$ & . & & & & & $\operatorname{tr}$ & \\
\hline$x$ & $x$ & & & & & $x$ & & \\
\hline$x$ & $x$ & & & & & & & \\
\hline$x$ & $x$ & & & & & & & tr. mont. \\
\hline$x$ & $x$ & & & & & & $\operatorname{tr}$ & \\
\hline$x$ & $x$ & & & & & & $\operatorname{tr}$ & \\
\hline$\ddot{x}$ & $\hat{x}$ & & & & & & $\operatorname{tr}$ & \\
\hline$x$ & $x$ & & & & & & $\operatorname{tr}$ & \\
\hline$x$ & $x$ & & & & & & $x$ & \\
\hline$x$ & $x$ & & $x$ & tr & & $x$ & & \\
\hline$x$ & $x$ & tr & $x$ & tr & & $\operatorname{tr}$ & $\operatorname{tr}$ & \\
\hline & & & & & & & & barite \\
\hline$x$ & $\operatorname{tr}$ & & & & & $x$ & & \\
\hline$x$ & $x$ & & $x$ & $x$ & & $x$ & & \\
\hline$\ddot{x}$ & $\operatorname{tr}$ & $\operatorname{tr}$ & $x$ & $x$ & & & & tr. mont. \\
\hline$x$ & $x$ & $\operatorname{tr}$ & $x$ & tr & & & & \\
\hline$x$ & $x$ & $x$ & $x$ & $x$ & & & & \\
\hline$x$ & $x$ & $x$ & $x$ & $\operatorname{tr}$ & & & & \\
\hline$x$ & $x$ & & $x$ & $x$ & & $\operatorname{tr}$ & & \\
\hline$x$ & $\operatorname{tr}$ & & $x$ & $x$ & & & & \\
\hline$x$ & & $\operatorname{tr}$ & $x$ & $x$ & & $\operatorname{tr}$ & &. \\
\hline$x$ & $x$ & $\operatorname{tr}$ & $x$ & $\operatorname{tr}$ & tr & $\operatorname{tr}$ & & . \\
\hline$x$ & $x$ & & $x$ & & tr & & & \\
\hline$x$ & $x$ & $x$ & $x$ & $\operatorname{tr}$ & & $\operatorname{tr}$ & & \\
\hline$x$ & $x$ & $x$ & $x$ & $\operatorname{tr}$ & tr & & $\operatorname{tr}$ & \\
\hline$x$ & $x$ & & $x$ & $x$ & $x$ & $\operatorname{tr}$ & & \\
\hline$x$ & $x$ & $\operatorname{tr}$ & $x$ & & & & & \\
\hline$x$ & $\operatorname{tr}$ & $x$ & $x$ & $x$ & $x$ & & & \\
\hline$x$ & $x$ & $x$ & $x$ & $\operatorname{tr}$ & $\operatorname{tr}$ & & & \\
\hline$x$ & $\operatorname{tr}$ & $\operatorname{tr}$ & $x$ & $x$ & $x$ & & & \\
\hline$x$ & $x$ & & $\operatorname{tr}$ & $x$ & $x$ & & $\operatorname{tr}$ & \\
\hline
\end{tabular}

\begin{tabular}{|c|c|c|c|c|c|c|c|c|}
\hline$x$ & $x$ & $x$ & & & & $x$ & $x$ & tr. mont. \\
\hline$x$ & $x$ & $x$ & & & & $x$ & $x$ & tr. mont. \\
\hline$x$ & $x$ & $x$ & tr & $x$ & tr & $x$ & & tr. mont. \\
\hline$x$ & $x$ & $x$ & $x$ & $\operatorname{tr}$ & & $x$ & $x$ & $x$ mont. \\
\hline$x$ & $x$ & & & & & & & \\
\hline$x$ & $x$ & & & & & & & \\
\hline$x$ & $x$ & & $x$ & & & & $x$ & tr. mont. \\
\hline$x$ & tr & & & & & - & & \\
\hline$x$ & $x$ & & & & & & & \\
\hline$x$ & $\operatorname{tr}$ & & & & & & & \\
\hline$x$ & $x$ & . & & & & & $\operatorname{tr}$ & \\
\hline$x$ & $x$ & & & & & $x$ & & \\
\hline$x$ & $x$ & & & & & & & \\
\hline$x$ & $x$ & & & & & & & tr. mont. \\
\hline$x$ & $x$ & & & & & & $\operatorname{tr}$ & \\
\hline$x$ & $x$ & & & & & & $\operatorname{tr}$ & \\
\hline$\ddot{x}$ & $\hat{x}$ & & & & & & $\operatorname{tr}$ & \\
\hline$x$ & $x$ & & & & & & $\operatorname{tr}$ & \\
\hline$x$ & $x$ & & & & & & $x$ & \\
\hline$x$ & $x$ & & $x$ & tr & & $x$ & & \\
\hline$x$ & $x$ & tr & $x$ & tr & & $\operatorname{tr}$ & $\operatorname{tr}$ & \\
\hline & & & & & & & & barite \\
\hline$x$ & $\operatorname{tr}$ & & & & & $x$ & & \\
\hline$x$ & $x$ & & $x$ & $x$ & & $x$ & & \\
\hline$\ddot{x}$ & $\operatorname{tr}$ & $\operatorname{tr}$ & $x$ & $x$ & & & & tr. mont. \\
\hline$x$ & $x$ & $\operatorname{tr}$ & $x$ & tr & & & & \\
\hline$x$ & $x$ & $x$ & $x$ & $x$ & & & & \\
\hline$x$ & $x$ & $x$ & $x$ & $\operatorname{tr}$ & & & & \\
\hline$x$ & $x$ & & $x$ & $x$ & & $\operatorname{tr}$ & & \\
\hline$x$ & $\operatorname{tr}$ & & $x$ & $x$ & & & & \\
\hline$x$ & & $\operatorname{tr}$ & $x$ & $x$ & & $\operatorname{tr}$ & &. \\
\hline$x$ & $x$ & $\operatorname{tr}$ & $x$ & $\operatorname{tr}$ & tr & $\operatorname{tr}$ & & . \\
\hline$x$ & $x$ & & $x$ & & tr & & & \\
\hline$x$ & $x$ & $x$ & $x$ & $\operatorname{tr}$ & & $\operatorname{tr}$ & & \\
\hline$x$ & $x$ & $x$ & $x$ & $\operatorname{tr}$ & tr & & $\operatorname{tr}$ & \\
\hline$x$ & $x$ & & $x$ & $x$ & $x$ & $\operatorname{tr}$ & & \\
\hline$x$ & $x$ & $\operatorname{tr}$ & $x$ & & & & & \\
\hline$x$ & $\operatorname{tr}$ & $x$ & $x$ & $x$ & $x$ & & & \\
\hline$x$ & $x$ & $x$ & $x$ & $\operatorname{tr}$ & $\operatorname{tr}$ & & & \\
\hline$x$ & $\operatorname{tr}$ & $\operatorname{tr}$ & $x$ & $x$ & $x$ & & & \\
\hline$x$ & $x$ & & $\operatorname{tr}$ & $x$ & $x$ & & $\operatorname{tr}$ & \\
\hline
\end{tabular}

\begin{tabular}{|c|c|c|c|c|c|c|c|c|}
\hline$x$ & $x$ & $x$ & & & & $x$ & $x$ & tr. mont. \\
\hline$x$ & $x$ & $x$ & & & & $x$ & $x$ & tr. mont. \\
\hline$x$ & $x$ & $x$ & tr & $x$ & tr & $x$ & & tr. mont. \\
\hline$x$ & $x$ & $x$ & $x$ & $\operatorname{tr}$ & & $x$ & $x$ & $x$ mont. \\
\hline$x$ & $x$ & & & & & & & \\
\hline$x$ & $x$ & & & & & & & \\
\hline$x$ & $x$ & & $x$ & & & & $x$ & tr. mont. \\
\hline$x$ & tr & & & & & - & & \\
\hline$x$ & $x$ & & & & & & & \\
\hline$x$ & $\operatorname{tr}$ & & & & & & & \\
\hline$x$ & $x$ & . & & & & & $\operatorname{tr}$ & \\
\hline$x$ & $x$ & & & & & $x$ & & \\
\hline$x$ & $x$ & & & & & & & \\
\hline$x$ & $x$ & & & & & & & tr. mont. \\
\hline$x$ & $x$ & & & & & & $\operatorname{tr}$ & \\
\hline$x$ & $x$ & & & & & & $\operatorname{tr}$ & \\
\hline$\ddot{x}$ & $\hat{x}$ & & & & & & $\operatorname{tr}$ & \\
\hline$x$ & $x$ & & & & & & $\operatorname{tr}$ & \\
\hline$x$ & $x$ & & & & & & $x$ & \\
\hline$x$ & $x$ & & $x$ & tr & & $x$ & & \\
\hline$x$ & $x$ & tr & $x$ & tr & & $\operatorname{tr}$ & $\operatorname{tr}$ & \\
\hline & & & & & & & & barite \\
\hline$x$ & $\operatorname{tr}$ & & & & & $x$ & & \\
\hline$x$ & $x$ & & $x$ & $x$ & & $x$ & & \\
\hline$\ddot{x}$ & $\operatorname{tr}$ & $\operatorname{tr}$ & $x$ & $x$ & & & & tr. mont. \\
\hline$x$ & $x$ & $\operatorname{tr}$ & $x$ & tr & & & & \\
\hline$x$ & $x$ & $x$ & $x$ & $x$ & & & & \\
\hline$x$ & $x$ & $x$ & $x$ & $\operatorname{tr}$ & & & & \\
\hline$x$ & $x$ & & $x$ & $x$ & & $\operatorname{tr}$ & & \\
\hline$x$ & $\operatorname{tr}$ & & $x$ & $x$ & & & & \\
\hline$x$ & & $\operatorname{tr}$ & $x$ & $x$ & & $\operatorname{tr}$ & &. \\
\hline$x$ & $x$ & $\operatorname{tr}$ & $x$ & $\operatorname{tr}$ & tr & $\operatorname{tr}$ & & . \\
\hline$x$ & $x$ & & $x$ & & tr & & & \\
\hline$x$ & $x$ & $x$ & $x$ & $\operatorname{tr}$ & & $\operatorname{tr}$ & & \\
\hline$x$ & $x$ & $x$ & $x$ & $\operatorname{tr}$ & tr & & $\operatorname{tr}$ & \\
\hline$x$ & $x$ & & $x$ & $x$ & $x$ & $\operatorname{tr}$ & & \\
\hline$x$ & $x$ & $\operatorname{tr}$ & $x$ & & & & & \\
\hline$x$ & $\operatorname{tr}$ & $x$ & $x$ & $x$ & $x$ & & & \\
\hline$x$ & $x$ & $x$ & $x$ & $\operatorname{tr}$ & $\operatorname{tr}$ & & & \\
\hline$x$ & $\operatorname{tr}$ & $\operatorname{tr}$ & $x$ & $x$ & $x$ & & & \\
\hline$x$ & $x$ & & $\operatorname{tr}$ & $x$ & $x$ & & $\operatorname{tr}$ & \\
\hline
\end{tabular}

\begin{tabular}{|c|c|c|c|c|c|c|c|c|}
\hline$x$ & $x$ & $x$ & & & \multirow{5}{*}{$\operatorname{tr}$} & \multirow{5}{*}{$\begin{array}{l}x \\
x \\
x \\
x\end{array}$} & \multirow{5}{*}{$\begin{array}{l}x \\
x \\
x\end{array}$} & \multirow{5}{*}{$\begin{array}{l}\text { tr. mont } \\
\text { tr. mont } \\
\text { tr. mont } \\
x \text { mont. }\end{array}$} \\
\hline$x$ & $x$ & $x$ & & & & & & \\
\hline$x$ & $x$ & $x$ & tr & $x$ & & & & \\
\hline$x$ & $x$ & $x$ & $\mathrm{x}$ & $\operatorname{tr}$ & & & & \\
\hline$x$ & $x$ & & & & & & & \\
\hline$x$ & $x$ & & & & & & & \\
\hline$x$ & $x$ & & $x$ & & & & $x$ & tr. mont. \\
\hline$x$ & $\operatorname{tr}$ & & & & & v & & \\
\hline$x$ & $x$ & & & & & & & \\
\hline$x$ & $\operatorname{tr}$ & & & & & & & \\
\hline$x$ & $x$ & · & & & & & $\operatorname{tr}$ & \\
\hline$x$ & $x$ & & & & & $x$ & & \\
\hline$x$ & $x$ & & & & & & & \\
\hline$x$ & $x$ & & & & & & & tr. mont. \\
\hline$x$ & $x$ & & & & & & $\operatorname{tr}$ & \\
\hline$x$ & $x$ & & & & & & $\operatorname{tr}$ & \\
\hline$\ddot{x}$ & $\hat{x}$ & & & & & & $\operatorname{tr}$ & \\
\hline$x$ & $x$ & & & & & & $\operatorname{tr}$ & \\
\hline$x$ & $x$ & & & & & & $x$ & \\
\hline$x$ & $x$ & & $x$ & $\mathrm{tr}$ & & $x$ & & \\
\hline$x$ & $x$ & tr & $x$ & tr & & $\mathrm{tr}$ & $\operatorname{tr}$ & \\
\hline & & & & & & & & barite \\
\hline$x$ & $\operatorname{tr}$ & & & & & $x$ & & \\
\hline$x$ & $x$ & & $x$ & $x$ & & $x$ & & \\
\hline$x$ & $\operatorname{tr}$ & $\operatorname{tr}$ & $x$ & $x$ & & & & tr. mont. \\
\hline$x$ & $x$ & $\operatorname{tr}$ & $x$ & tr & & & & \\
\hline$x$ & $x$ & $x$ & $x$ & $x$ & & & & \\
\hline$x$ & $x$ & $x$ & $x$ & $\operatorname{tr}$ & & & & \\
\hline$x$ & $x$ & & $x$ & $x$ & & $\operatorname{tr}$ & & \\
\hline$x$ & $\operatorname{tr}$ & & $x$ & $x$ & & & & \\
\hline$x$ & & $\operatorname{tr}$ & $x$ & $x$ & & tr & & \\
\hline$x$ & $x$ & $\mathrm{tr}$ & $x$ & tr & $\operatorname{tr}$ & $\operatorname{tr}$ & & . \\
\hline$x$ & $x$ & & $x$ & & $\operatorname{tr}$ & & & . \\
\hline$x$ & $x$ & $x$ & $x$ & $\operatorname{tr}$ & & $\operatorname{tr}$ & & \\
\hline$x$ & $x$ & $x$ & $x$ & $\operatorname{tr}$ & $\operatorname{tr}$ & & $\operatorname{tr}$ & \\
\hline$x$ & $x$ & & $x$ & $x$ & $x$ & $\operatorname{tr}$ & & \\
\hline$x$ & $x$ & $\operatorname{tr}$ & $x$ & & & & & \\
\hline$x$ & $\operatorname{tr}$ & $x$ & $x$ & $x$ & $x$ & & & \\
\hline$x$ & $x$ & $x$ & $x$ & $\operatorname{tr}$ & $\operatorname{tr}$ & & & \\
\hline$x$ & $\operatorname{tr}$ & $\operatorname{tr}$ & $x$ & $x$ & $x$ & & & \\
\hline$x$ & $x$ & & $\operatorname{tr}$ & $x$ & $x$ & & $\operatorname{tr}$ & \\
\hline
\end{tabular}

Notes: $x=$ major component $x=$ moderate to minor component $t r=$ trace

\begin{tabular}{llll}
\hline$x$ & tr & tr & \\
$x$ & tr & tr & tr \\
$x$ & $x$ & & tr \\
$x$ & tr & tr &
\end{tabular}


TABLE 15

Mineralogy of $0-1$ and P-1 Well Cuttings Determined by X-ray Diffractometer (continued)

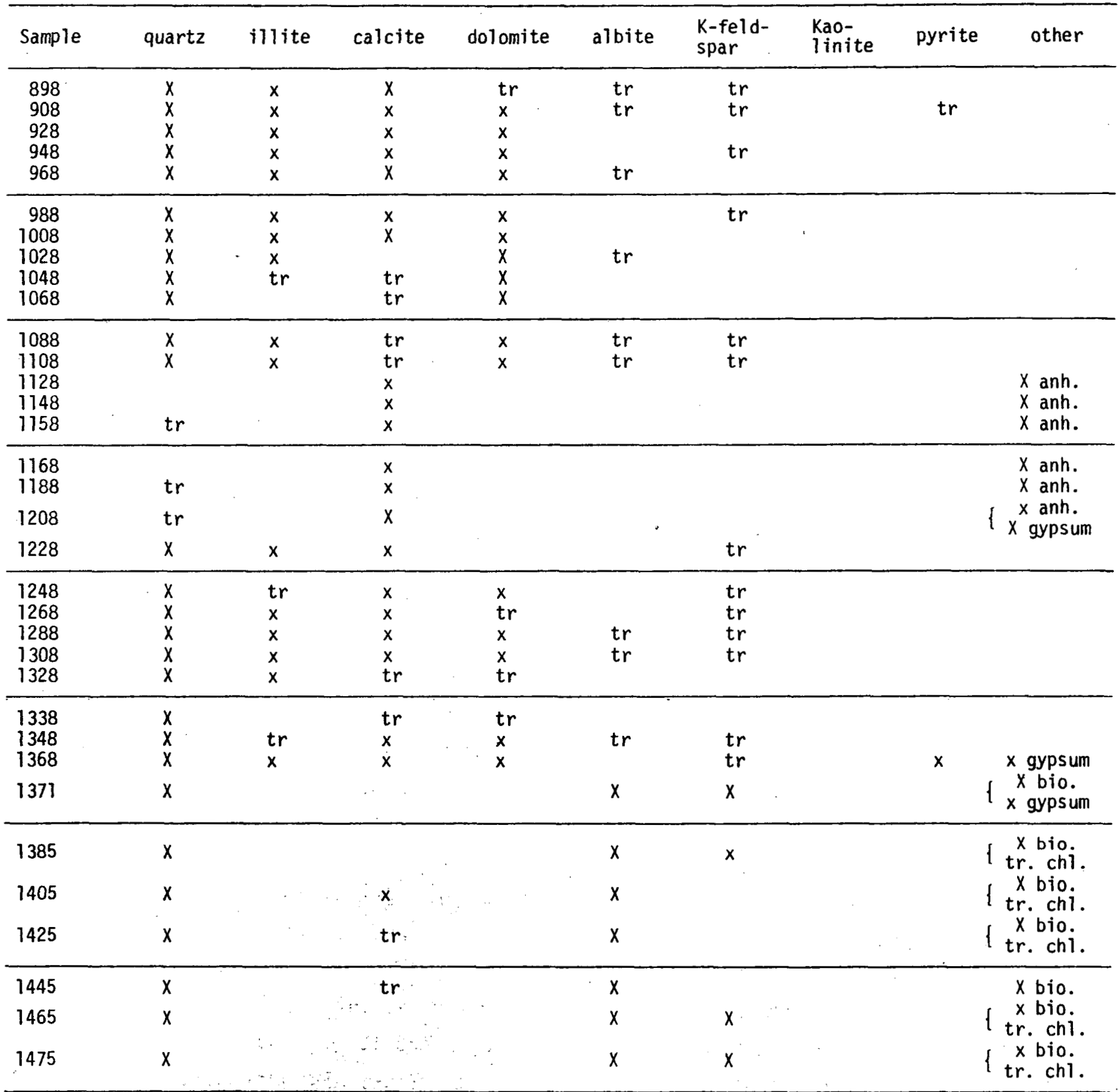

Notes: $X=$ major component $x=$ moderate to minor component $t r=$ trace mont. $=$ montmorillonite ahn. = anhydrite bio. = biotite chl. = chlorite.

Most samples from 1371 to 1475 contain traces to minor amounts of epidote. In most cases it was not possible to discriminate orthoclase from microcline, so that the presence of either is given as $K$-feidspar. In a few cases the $x$-ray pattern indicated microcline. Muscovite could not be discriminated from biotite in samples 1371-1475 due to interfering peaks. See sample descriptions for additional mineralogical information. 


\section{Thin Sections}

Seventeen thin sections of sedimentary rocks, primarily sandstones, were studied by Gary Mitch. His results are given in detail in Table 16. Additional data on mineralogy is provided by this study. In some cases minerals which could not be detected in the $x$-ray study were found in thin section. The study also provides information on the diagenetic history of the sediments.

Three thin sections of Precambrian metamorphic and igneous rocks from the bottom of the hole were also studied. Data on these samples is summarized in Table 17.

\section{Discussion of Results}

\section{Hydrothermal Activity}

Information on hydrothermal activity of the geothermal system is the primary interest in the present work. Much of the information obtained is unfortunately not diagnostic of hydrothermal activity. This is primarily because diagenetic processes produce mineralogy and textures similar to those produced by hydrothermal fluids. Examples of these sorts of features include alteration of feldspars to kaolinite and sericite, quartz overgrowths on sand grains, and carbonate cement. Even the crusts of euhedral pyrite and quartz in veins are, by themselves, not conclusively indicative of hot water, but require proof in the form of fluid inclusions. Finally, diagenetic illite and kaolinite are identical with hydrothermal sericite and kaolinite.

The occurrence of barite and chalcopyrite are suggestive of hydrothermal activity. Barite occurs as a diagenetic mineral only very rarely, and in such cases forms spheroidal concretions of radially fibrous crystals. Chalcopyrite has been réported as a mineral produced by supergene processes in copper deposits, but the single, euhedral crystals observed in well P-1 at $728 \mathrm{ft}$ depth must be regarded as hydrothermal. The habit of quartz crystals observed is elongated, with prominent prism faces. This is typical of hydrothermal veins, whereas quartz formed at low temperatures by surficial processes typically grow in radial clusters, with only rhombohedral faces exposed. This includes geodes and crusts on fractures. Such information is only qualitative, of course, and does not give much indication of how high temperatures may have been. 
The most important information was obtained from fluid inclusions in the hydrothermal quartz from the sample at $248 \mathrm{ft}$. It is probable that the thermal history of the system is recorded in inclusions, with some trapped at the maximum temperature, and many during the period of cooling. Those trapped during rising temperatures might be expected to leak due to rising internal pressure and be sealed again later. When temperatures ceased rising, the tendency to rupture would stop, and fluid would be trapped at the maximum temperature, or during the cooling period.

The maximum temperature obtained, $252.1^{\circ} \mathrm{C}$, may not be reliable, since the inclusion leaked afterward. The filling temperature of $230.5^{\circ} \mathrm{C}$ is probably good, since it was replicated four times before the inclusion may have begun to leak. The maximum temperature estimated from ratios of volumes of the bubble to total inclusion was $232^{\circ} \mathrm{C}$. The agreement between the two data is welcome, but since so few inclusions were found which could be measured, this may not be representative of the maximum temperature attained by the system at the depth sampled.

Water at a temperature of $230^{\circ} \mathrm{C}$ must be confined by a pressure of at least 28 $\mathrm{kg} / \mathrm{cm}^{2}$, or it will boil. It is probable that the geothermal system at Pagosa Springs has been open to the surface for most of its history, so that this pressure was applied by a hydrostatic head alone. That is, the system was not subject to lithostatic pressure. If this is true, the minimum depth of formation of the fluid inclusions can be calculated. If the overlying column of water were al1 at $25^{\circ} \mathrm{C}$, this would provide the maximum density to contain the pressure, and hence a minimum depth. A column of water $1087 \mathrm{ft}$ above the inclusions would provide a pressure of $28 \mathrm{~kg} / \mathrm{cm}^{2}$. It is not too likely that the overlying water was entirely this cool, however. Another possibility is that from the surface to the site of inclusion entrapment, all the water is at the boiling temperature. This would provide the lowest possible water density. The depth from the surface would be about $1260 \mathrm{ft}$. Any amount of cooler water could be present; so that a column of water intermediate between 1087 and $1260 \mathrm{ft}$ could provide the pressure. A third possibility is that the pressure was actually higher, and the depth is greater, but indeterminate. This last possibility is more probable, since no evidence of boiling was observed. The inclusions studied occurred at a depth of only $248 \mathrm{ft}$. Since the minimum possible depth of origin lies between 1087 and 
$1260 \mathrm{ft}$, this means that at least 800 to $1000 \mathrm{ft}$ of overburden have eroded off since the inclusions were trapped. This further suggests a minimum age of the system, based on the rate of erosion.

The occurrence of pyrite and euhedral vein quartz shows a relation to lithology of the host rocks. All were sandstones, mostly with a low clay content. The rocks were therefore either permeable or brittle, capable of maintaining open fractures. Quartz and pyrite were observed in the Dakota Sandstone at 241, 264, 339, and 399 $\mathrm{ft}$. In the Morrison Formation, which consists mostiy of clay-rich beds, quartz and pyrite occur only in relatively thin sandstone beds, at depths of 499, 599, 655,728 (chalcopyrite here), and $798 \mathrm{ft}$. The Wanakah consists of 1 imestone and anhydrite, and apparently was impermeable. Below, a little pyrite was observed in the Entrada Sandstone at 1228 and $1308 \mathrm{ft}$. At 1258, pyrite occurred in $1-2 \mathrm{~mm}$ thick veinlets.

It appears that the wells $0-1$ and $P-1$ were not within the central part of the hydrothermal system at depth, although this location was within reach of the mineralizing water. Results will have to be obtained from other wells in the future to locate the central part of the system.

\section{Lithology}

Information obtained from visual logging, $x$-ray work, and thin section studies may be helpful to other workers regarding the lithologies and thicknesses of rocks drilled.

From the samples of cuttings, some limits may be placed on the depths of sedimentary contacts. At $284 \mathrm{ft}$, the rock is shale with sandy lenses, whereas at $299 \mathrm{ft}$ the rock is sandstone. The base of the Dakota appears to lie between 422 and 459 , the latter depth at which clay-rich sandy rocks first appear. The base of the Morrison occurs between 1108 and 1118, while the base of the limestone in the Wanakah was observed between 1208 and 1218. No strong lithologic difference was noted between the sandstone in the internal 1218-1278 and that below from 1298 to 1368. Both intervals may belong to the Entrada. At 1371, the top of the Precambrian was encountered. 
Within the Morrison Formation many samples consisted of clay with variable amounts of quartz sand. Close examination of these samples revealed a granular structure in the clay, on the same scale as the quartz grains. It appears that the clay originally consisted of lithic fragments, probably of volcanic origin. The abundance of feldspar in the clay is also suggestive of such origin. These rocks have been termed "lithic sandstones" in the logging notes, but might also be called "diagenetic shales", in accordance with their present properties.

Precambrian rocks at the bottom of the hole exhibit normal mineralogy for rocks of this age in the Rocky Mountain area. Weak alteration observed in thin section of 1479 and 1481 is typical of metamorphic effects, and not that associated with hydrothermal alteration. The latter is typically guided by fractures, and destroys feldspars, particularly plagioclase, and biotite.

The very strong alteration at 1371 may be due to pre-Entrada weathering. This is particularly suggested by the replacement of biotite by hematite. Elsewhere in the we11, where hydrothermal minerals occurred, hematite was not observed. The most prevalent hydrothermal mineral, pyrite, does not occur at 1371 . It appears, then, that the alteration at this depth is not hydrothermal, and that the geothermal system did not reach this point in the well.

\section{Potassium-Argon Date on Precambrian Rocks}

A potassium-Argon date was obtained on biotite from the granite cored in Well P-1 between 1475.3 and 1477.6 feet. The entire granite interval was split and half was submitted to Geochron Laboratories Division of Krueger Enterprises, Inc., in Cambridge, Mass. There, the rock was crushed and biotite separated for the determination. The age obtained was $1152 \pm 39$ million years. It is Precambrian, as expected from the lithology.

Precambrian rocks from the southern Rocky Mountains region typically reflect a history of folding, metamorphism and intrusion by granitic rocks about 1700 million years ago, and a second event characterized by granitic intrusions about 1400 m.y. Locally, later events, such as the intrusion of Pike's Peak granite (1015 m.y.) lowered the mica ages or rocks (Hedge, et al., 1968; Hansen and Peterman, 1968). Giffin and Kulp (1960) determined potassium-argon ages of 
Precambrian rocks in south-central Colorado, obtaining numbers from 980 to 1540 m.y. One specimen, a biotite gneiss, yielded a date of $1130 \mathrm{~m} . \mathrm{y}$. , very close to the age of the Pagosa Springs granite sample. The biotite gneiss was collected between Cimarron and Sapinero, just west of Gunnison, and about 85 miles north of Pagosa Springs. Hansen and Peterman (1968) obtained Rb-Sr dates of $1190 \pm 60 \mathrm{~m} . \mathrm{y}$. on two quartz monzonites from the Black Canyon of the Gunnison, although a K-Ar date on one of the specimens was $1220 \pm 40 \mathrm{~m} . \mathrm{y}$. These results suggest that the date on the Pagosa Springs sample is not anomalous, and has not been re-set by hydrothermal activity from the hot springs. This is the opinion of Carl Hedge, U.S. Geological Survey, Denver (personal communication), with whom the writer concurs. 
Table 16

Thin Section Studies of Sedimentary Rocks

by Gary Mitch

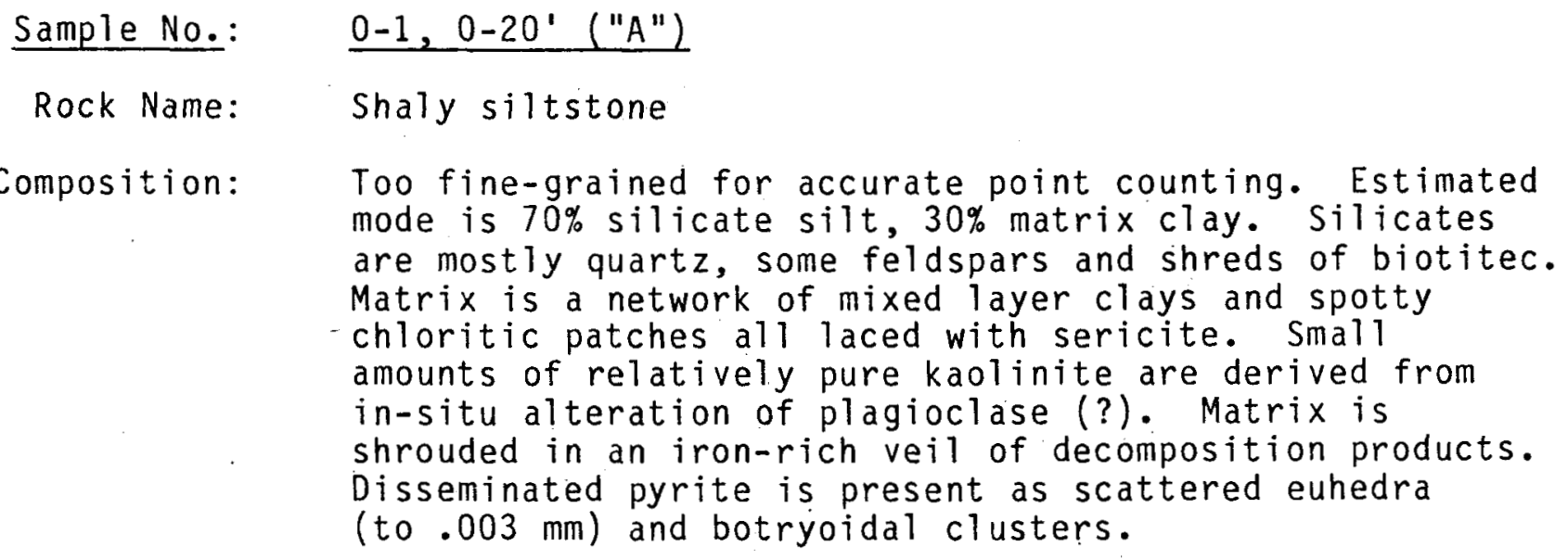

Texture: No bedding laminations seen in thin section. Silt ranges up to $.06 \mathrm{~mm}$, averages $=.03 \mathrm{~mm}$, and is subrounded to angular. Sorting is good.

Alterations: $\quad$ Much overgrowth silica is altering to chert and can be traced through many transitional stages.

Sample No.: $\quad \underline{0-1,241-244}$

Rock Name: $\quad$ silty shale with sandy laminae

Composition: Too fine-grained for modal analysis. Silt generally looks quartzose. Matrix clays are heavily coated with iron oxides and an aggregate extinction is present. Matrix is peppered with pyrite which, except for veins (see below), shows a weak alinement within bedding or no site preference at all.

Texture: Laminae in the sample are about $1 / 4 \mathrm{~mm}$ thick and are apparent from concentrations of fine sand, coarse silt or layers unusually rich in iron oxides or carbonaceous (?) matter. "Fractures, fairly consistent at 50' to bedding are present and filled with euhedral quartz and pyrite.

Alterations: $\quad$ other than vein fillings, the silicate silt is peripherally altering to matrix clays. Alteration of pyrite likely contributes much of the matrix iron oxides.

Sample No.: $\quad 0-1,264$

Rock Name: quartz wacke 
Composition: - Frameworks 70 matrix 28 other 2 (rock fragments, pyrite). Framework fraction is virtually all quartz. These grains are variably strained and contain plutonic accessory minerals. Rock fragments are usually chert. Pyrite is scattered throughout and is occasionally in streaky laminea-like layers. Matrix is composed of mixed layer clay assemblages laced with sericite or illite.

Texture: $\quad$ Amount of matrix alternates between crude layers. Matrix-poor zones show early compaction effects of long and sutured.grain contacts and many quartz overgrowths. Matrix-rich zones generally retain a grain support fabric and still show. significant overgrowth rims and suturing bétween grains. Quartz grains are quite variable in. shape (angular to round) but fairly consistent in size, averaging $1 / 10 \mathrm{~mm}$ (very fine sand).

Alterations: $\quad \therefore$ Framework grain-matrix borders in the matrix poor zones are complex, with peripheral alteration to the matrix clays. Sutured aggregates of grains in these areas are undergoing dissegregation from clays working in along internal grain contacts. These alterations are more advanced in the matrix rich areas, which accounts for the increased amount of clays. Matrix supported, sutured grain aggregates al so support a diagenetic origin for this clay product. "Thus the matrix rich and matrix poor zones likely reflect different stages of diagenesis.

Sample No.: $\quad \underline{0-1,319-322}$

Rock Name: $\quad$ quartz alrenite cemented with quartz

Composition: Quartz.95 grains 80 cement 15 other 5 (rock fragments feldspar, opaques). Mineralogically quite simple in that virtually all grains are quartz sand. Remainder is quantitatively minor rock fragments and a few feldspar grajns. Trace amounts of ilmenite (altered to leucoxene) and pyrite at present. Quartz cement is present as syntaxial overgrowths on grains.

Texture: Quartz grains are tight and interlocking reflecting a porosity decrease during initial compaction with resulting pressure welding and precipitation of the overgrowths. Quartz grains are in the fine sand fraction $(1 / 8-1 / 4 \mathrm{~mm})$. Original grain boundaries at the base of the overgrowths show the quartz to have been well rounded and well sorted. Feldspars and rock fragments were compacted and sutured with the quartz. Some of these grains were also apparently squashed between compacting quartz grains.

Alterations: Virtually all the feldspar and rock fragments have altered to clays and sericite. These products are observed occupying dispersed grain positions. Relict plagioclase. twins and alteration product inhomogeneities indicate the 
former presence of feldspar and rock fragments

respectively. Dark colored material bearing opaques

(pyrite, hematite) occurs along some grain borders.

Sample No.: $\quad \underline{0-1,399-402}$

Rock Name: quartz arenite

Composition: Quartz 90 other 10 (chert, clay, pyrite, rock fragments, voids). Quartz grains show variable strain and inherited inclusions and are cemented from pressure welding and optically continuous overgrowths. Rock fragments are largely altered to mixed layer clay assemblages. Pyrite fills voids, lines chert and clay pseudomorphs of framework grains, replaces into them and occurs along intact grain boundaries.

Texture: Grain fabric is tight and interlocking from pressure solution resulting in suturing of grains and precipitation of overgrowths. The voids present could be from flushing of post-depositional clay pseudomorphs of unstable frameworks. Original quartz borders below overgrowths show that the grains, before compaction, were generally very round, ranged from $1 / 3-1 / 2 \mathrm{~mm}$ in size (medium sand) and were well sorted.

Alterations: Unstable framework grains have altered to clays which corroded adjacent quartz grains. Many quartz overgrowths and grains are degrading to chert. These processes have. produced clay and chert pseudomorphs of frameworks. Pyrite has moved in along fractures and grain boundaries, filled voids (from flushing of pseudomorphs (?) and localized around pseudomorphs.

Sample No.: $\quad \underline{0-1,499-504}$

Rock Name: feldspathic wacke

Composition: Quartz and feldpsar 58 clays 28 carbonate 13 other 1 (muscovite, pyrite, rock fragments). Distinguishing feldspar and quartz was not attempted as much of the plagioclase as untwinned. Both microline and plagiocalse are present. Quartz is typically clear, somewhat strained, and bears sytnaxial overgrowths. A small amount of pyrite - no specific distribution - is present, as are some shreds of detrital muscovite clays are kaolinitic and authigenic. The carbonate (calcite ?) appears to be a late cement.

Texture: $\quad$ Major framework grains average $0.2 \mathrm{~mm}$ (fine sand) in diameter. Sorting and grain roundness have been degraded by diagenetic alterations. The presence of syntaxial overgrowths and sutures on floating grains alludes to an early compaction history. The grain dispersal we see now is due to clay production through alteration of grains. 
Alterations: The clay present is derived from alteration of framework grains, particularly feldspars, rock fragments and syntaxial overgrowths. The clay production disaggregates grains and disperses the framework: The carbonate present is believed to be a late introduced cement as it appears to transect all the textures and embays all sample constituents.

Sample No.: $\quad \underline{0-1,655-659}$

Rock Name: ..feldspathic wacke

Composition: Frameworks 46 carbonate 28 clays $26 \mathrm{tr}$. opaques, tourmaline. Owing to difficulty in distinguishing untwinned plagioclase, feldspars were not tabulated separately but combined with quartz in the framework count. This fraction is estimated at $85 \%$ quartz, $15 \%$ feldspars. - Frameworks are all variably altered. Clay is probably all authigenic and contains some areas of relatively. pure kaolinite but includes much mixed layer types and illite or sercite. In light of the alterations, modal feldspar has diminished through time. Dolomite is present as a late (?) cement.

Texture: $\quad$ Frameworks appear moderately sorted and of very fine sand $(1 / 10 \mathrm{~mm})$ size. Grain shapes vary widely (angular to round) but this is partially due to the wholesale grain alterations (to clays) that are tending to disperse the framework. . Precipitated syntaxial overgrowths and welded grain contacts are still present and their distribution and occurrence indicate a tightly welded framework following initial compaction.

Alterations: Virtually all grains, but particularly feldspars, are altering to clays - some to near obliteration. Grains are found in all stages of alteration from peripheral degradation to minute remnant grain shreds in grain-sized clay patches: Clay pseudomorphs are present. Carbonate appears to be a late cement, post-dating much of the alteration - but this is unclear as carbonate cement patches are turbid and veiled.

Sample No.: $\quad \underline{p-1,728}$

Rock Name: sub feldspathic arenite

Composition: Quartz 67 feldspar 9 cement (silica) 8 cement (carbonate) 16. Quartz grains are variably strained and commonly bear syntaxial overgrowths. Feldspars include both plagioclase and microcline and show some alterations but are generally intact. Some of this alteration is likely to be source area weathering. Carbonate cement is dolomite.

Texture: Framework quartz is subrounded and averaging $1 / 4 \mathrm{~mm}$ 
grain diameters (fine sand). Feldspars are similary sized but are more angular owing to cleavage. The sample is well sorted and the carbonate cement poikilotopically encloses framework grains.

Alterations: $\quad$ Frameworks are all relatively intact but undergoing peripheral etching by the carbonate cement. In some instances almost entire grains have been obliterated. Syntaxial overgrowths show more extensive replacement by the carbonate.

Sample No.: $\quad \underline{P-1,828}$

Rock Name: feldspathic wacke

Composition: Quartz 46 feldspar 19 clays 15 carbonbate 20. Quartz grains are variabley strained and commonly have syntaxial. cvergrowths. Trace amounts of detrital opaques are present along with some disseminated authogenic hematite. Carbonate cement cross cuts most grains.

Texture: $\quad$ Frameworks range fromn silt to $1 / 2 \mathrm{~mm}$ but average in the fine sand grade $(1 / 8-14 \mathrm{~mm})$. Grains are subangular to subrounded and the sample looks well sorted. Grains shapes are modified by peripheral alterations. Modal feldspar is being decreased by alteration to clay and this increases the amount of matrix present as grains are replaced and disaggregated.

Alterations: The feldspar grain interiors preserve what might be minor source area weathering. Borders of these and quartz grains and overgrowths are being replaced, in-situ, by clays. All stages of alteration can be seen. Trace opaques have oxidized. Carbonate-clay relations are unclear; the carbonate appears to postdate major clay alterations.

Sample No.: $\quad \underline{P-1,878}$

Rock Name: quarti arenite

Composition: Frameworks 63 carbonate 21 clays, mica 12 other 4 (pyroxene, opaques). Framework feldspar are often untwinned fragments or whole grains difficult to segregate from quartz except for microcline. Clay matrix includes some kaolinite and much mixed layer types with micromicas (chlorite, sericite ?) in a network around grains. Matrix contains much disseminated hematite. Carbonate cement is cloudy.

Texture: Frameworks are well sorted and grain sizes range from silt to $1 / 8 \mathrm{~mm}$, averaging about $1 \% 10 \mathrm{~mm}$ (very fine sand). These are subangular to subrounded. Carbonate cement is patchy but encloses these and their clay pseudomorphs. A more extensive mixed-layer clay assemblage and micormica network pervade the framework and appear to enclose 
carbonate patches too. Sporadically preserved grain overgrowths and sutured and long grain contacts indicate an early compaction.

Alterations: Early feldspar alteration is preserved as kaolinitic patches. Carbonate cement appears to have been introduced later and has etched and embayed framework grains. Later development of mixed layer clay assemblages, appear to corrode all constituents and the late micromica network follows manmy intergrain borders and appears to even surround some carbonate cement patches.

Sample No.: : $\quad \underline{P-1,888}$

Rock Name:

Composition:

Texture:

\section{quartzose siltstone}

Silt 70 matrix 30 (visual estimation). Silt consists largely of quartz; microcline and plagioclase are present also and show as twinned grains and cleaved fragments. Some chert fragments and detrital heavy minerals are present. Matrix appears to be largely a mixed-layer clay assemblage with portions which have much micromica (chlorite, sericite). Matrix contains much disseminated hematite. Some carbonate occurs in the matrix.

Textural relations are largely veiled by the matrix impurities. Silt averages $1 / 25 \mathrm{~mm}$ in grain diameter (medium-coarse silt) and is subrounded to angular in shape; many grains are cleavage fragments. Sorting in the silt is poor to moderate.

Alterations: Silt is being perhipherally altered to matrix clays but this is not likely to be extensive. The carbonate may be reconstituted detritus, but is quantitatively minor.

Sample No.: $\quad \underline{P-1}, 908$

Rock Name: feldspathic arenite

Composition: Quartz 51 fed 14 carb 28 clay 5 other 2 (rock... fragments, 2 iron). Quartz occurs as single grains, variably strained and rutilated, and polycrystalline grains, chert, and meta-quartz rock fragments. Feldspar fraction includes both microcline $(75 \%)$ and plagioclase $(25 \%)$. Clay includes kaolinate and mixed layer-assemblages. The carbonate occurs as a cement and hematite is disseminated throughout.

Texture: $\quad$ Carbonate cement poikilotopically encloses framework grains. Frameworks range from fine silt to $1 / 8 \mathrm{~mm}$ in grain diameters (very fine sand) and are well sorted. Grain shapes vary from subangular to angular with few larger subrounded quartz grains. Grain size and shape has been altered somewhat by the carbonate cement etching peripheries. 
Alterations: The carbonate cement, an early void filler, has etched and corroded the framework grains it encloses. Subsequent kaolinization of feldspars has left cement enclosed clay patches. These have etched back into the carbonate along with mixed layer clays which may represent altered rock fragments. "Late peripheral alteration has produced micromica networks along grain boundaries and these appear to enclose some carbonate cement also.

Sample No.: $\quad \underline{P-1,988}$

Rock Name: $\quad$ Sub feldspathic to quartz arenite

Composition:

Quartz 43 carbonate 40 f eldspar 10 clay 5-8 other 1 (rock fragments). Quartz is variably strained and corroded by the carbonate, which is the major binder in the sample. Overgrowths on grains are not extensive. Clays include kaolinitic and mixed-layer assemblages. Feldspars include both plagioclase and microcline.

Texture: Carbonate dominates the sample. Its texture is granoblastic and it embays most grains and is tending to disperse the framework. Frameworks are in the fine sand range (1/8-1/4 mm) but grain size and shape are effectively altered from peripheral replacement by carbonate.

Alterations: The high modal per cent (40) of carbonate cement and its granoblastic texture suggest it to be a late replacement. It corrodes, embays, and has fairly extensively replaced many framework grains. It is as likely, though less clear, that the carbonate is also engulfing clays produced from alteration of a once greater feldspar fraction.

Sample No.: $\quad \underline{P-1,1018}$

Rock Name: feldspathic wacke

Composition: Frameworks 70 mica \& clay 15 carbonate 12 other 3 (chert, rock fragments, hornblende, zireon). Quartz feldspar are distinguished with difficulty, owing to untwinned plagioclase. Much of the feldspar is more altered and cleaved relative to quartz and a visual estimation places felspar in excess of $10 \%$ rock volume. This may be all plagioclase. No microcline was seen. Matrix clays are authigenic and have kaolinitic patches but are strongly illitic (?). Many frameworks have mica envelopes which, owing to the long flake dimensions, it judged to be sericitic muscovite. The carbonate is late cement.

Texture: $\quad$ Framework grains range $1 / 4-1 / 10 \mathrm{~mm}$ and average within the fine sand fraction $(1 / 5-1 / 10 \mathrm{~mm})$. The sample is well. sorted and grain shapes are subrounded to subangular, excluding obvious cleavage fragments which are distinctly angular. Grain boundary sutures and overgrowths 
Matrix clays can be seen to accumulate from in-situ breakdown of feldspars. The carbonate cement corrodes and embays most framework grains and appears to be encroaching on the authigenic clays but this cannot be determined with certainty. Late recrystallization has produced the mica envelopes on frameworks and this does appear to enclose carbonate also.

Sample No.: $\quad \underline{P-1,1078 A}$

Rock Name: $\quad$ Silty shale, some scattered sand

Composition:

Sample is too fine grained for modal analysis but visual estimation places the sand/silt fraction at 30\%. This sand and silt is largely quartz with lesser feldspar and is enclosed in a brownish clay matrix that is heavily oxidized but can be seen to still contain disseminated pyrite in descrete euhedra and small clusters. Disseminated and blebby hematite account for the reddish brown color. Trace amounts of other silicates (e.g., tourmaline) are present. Some carbonate is present.

Texture: No obvious stratification is present in thin section. Carbonate occurs as vein filler and in discrete patches that may be reconstituted detritus.

Alterations: $\quad$ Matrix clays are oxidized, silt and sand grains are peripherally altered to matrix clays but the extent of this cannot be determined.

Sample No:: $\quad \underline{P-1,1078 B}$

Rock Name: $\quad$ shaly siltstone, quartzose

Composition:

Too fine-grained for modal analysis. Silt fraction comprises over $50 \%$ of the sample and contains virtually al1 quartz and feldspar. This is bound in a heterogeneous clay matrix carrying small amounts of detrital biotite, dispersed hematite, sericite, illite and stringers and patches of turbid hematitic carbonate cement.

Texture: Silt grains are subangular to subrounded and are moderately-to-well-sorted. Textural reations are generally clouded by dispersed oxides and other impurities in the binders.

Alterrations: Most silt is corroded and embayed by the binding material.

Sample No.: $\quad \underline{P-1,1258}$

Rock Name: $\quad$ subfeldspathic arenite

Composition: Quartz 59 feldspar 7 carbonate 21 clay 8 other 5 (rock 
Texture: $\quad$ Carbonate cement poikilotopically encloses many framework grains and is interpreted as an early void filling cement. Grain overgrowths and long grain contacts point to an early compaction event but again, the carbonate signifies preservation of significant void space following this. Grain diameters range from coarse silt to $3 / 4 \mathrm{~mm}$ and average about $1 / 4 \mathrm{~mm}$ (fine-medium sand). Sorting is moderate, grain shapes are subrounded, but etching by cement has increased angularity on many.

Alterations: The carbonate cement has extensively etched or corroded the framework grains. Kaolinite patches enclosed by this cement suggest that feldspar alteration followed cementation but subsequent clay-carbonate relations are problematical. In some cases, the carbonate appears to have later been corroded back by the authigenic clay. In other grains, the replacement clay appears to merely abut the cement fabric. Micromica envelopes around many grains are the result of a late recrystallization of matrix clays.

Sample No.: $\quad \underline{P-1,1268}$

Rock Name: $\quad$ subfeldspathic arenite grading to subfeldspathic wacke

Composition: Quartz 53 feldspar 11 carbonate 15 clays 14-18 other 3 (rock fragments, pyrite)

Sample is essentially the same as $P-1,1258$ but with the following differences:

1) modal feldspar includes significant microcline

2) there is less carbonate, more clay in this sample, more mixed layer clays

3) illite appears better developed here in the matrix and on feldspars

Textural relations and alterations are essentially the same. 
Table 17

Thin Section Studies of Pre-Cambrian

Metamorphic and Igneous Rocks

$P-1,1371$

Mineralogy:

quartz, about $20 \%$

biotite, about $10 \%$

altered plagioclase, about $60 \%$

microcline, about $10 \%$

Texture: equigranular, xenomorphic

Remarks :

Plagioclase is completely altered to a mixture of carbonate and sericite.

Biotite is partly altered to hematite.

Rock Type: granite gneiss, or gneissic granite.

$P-1,1479$

Mineralogy:

quartz

microcline

$47.1 \%$

$13.4 \%$

plagioclase $\left(\mathrm{An}_{32}\right) \quad 24.7 \%$

coarse muscovite $6.6 \%$

epidote $2.7 \%$

apatite $0.7 \%$

chlorite $0.3 \%$

biotite. $4.5 \%$

sericite $\quad t r$

zircon tr

metamict allanite ? $=\frac{t r}{100.0 \%}$

Texture: equigranular, xenomorphic

Remarks:

Quartz and coarse microcline occur. in closts surrounded by a mixture of coarse plagioclase, biotite, fine-grained quartz and epidote.

Microline is slightly perthitic. It shows rare graphic intergrowths with quartz.

Plagioclase locally shows albite twinning, where it gives a composition of $\mathrm{An}_{32}$ based on extinction angles. Elsewhere it appears to have been replaced by a dirty-appearing, optically negative, untwinned feldspar; intergrown with biotite, sericite, coarse muscovite and locally by epidote. No clear difference in index occurs between the two, however. 
Rock Type: Granodiorite

$P-1,1481$

Mineralogy:

$\begin{array}{lr}\text { plagioclase }\left(\mathrm{An}_{32}\right) & 37.3 \% \\ \text { biotite } & 36.2 \% \\ \text { coarse muscovite } & 3.8 \% \\ \text { sericite } & 9.3 \% \\ \text { carbonate } & 3.6 \% \\ \text { epidote } & 7.8 \% \\ \text { chlorite } & 2.0 \% \\ & 100.0 \%\end{array}$

Texture: gneissic to schistose

Remarks:

Biotite is euhedral, with a sitrong foliation

Plagioclase is largely untwinned, optically negative, and gives a composition of $\mathrm{An}_{32}$ based on extinction angles. It is randomily replaced by epidote. Elsewhere it is randomly partiy sericitized.

Epidote occurs in clots up to several $\mathrm{mm}$ diameter with coarse muscovite and carbonate, with placjoclase mostly absent or replaced. Foliation is deflected around these clots, so it appears that deformation is partly postalteration, and probably pre-Cambrian in age.

1000 points counted.

Rock Type: Biotite plagioclase schist. 
Barrett, J.K., and Pearl, R.H., 1976, Hydrogeological data of thermal springs and wells in Colorado: Colo. Geol. Survey Inf. Series 6, 124 p.

1978, An appraisal of Colorado!s geothermal resources: Colorado Geol. Survey Bu11. 39, 224 p.

Batzle, M.L., Shirey, S.B., Simmons, Gene, 1978, Correlation of physical properties with microfracture characteristics [abs.]: Geological Society of America Abstracts with program (Rocky Mountain Section), v. 10, no. 5, p. 210 .

Craig, H., 1963, The isotopic geochemistry of water and carbon in geothermal areas, in E. Tongiogi, ed., Nuclear geology of geothermal areas: Spoleto, Italy, $284 \mathrm{p}$.

Davis, S.N., and Tuck, L.J., 1964, Optimum depth of wells in crystalline rocks: Groundwater, v. 2; p. 6-11.

Dunn, D.E., 1964, Evolution of the Chama basin and Archuleta anticlinorium, eastern Archuleta County, Colorado: Univ. of Texas Ph.D., thes is available from Univ. Microfilms Inc., Ann Arbor, Michigan, $114 \mathrm{p}$.

Galloway, M.J., 1977, Water circulation model for hot springs in fractured crystalline rock [abs.]: Geol. Soc. America Abstracts with Program (Rocky Mountain Section), v.. 9, no. 6, p. 725.

Giffin, C.E., and Kulp, J.L., 1960, Potassium-argon ages in the Precambrian basement of Colorado: Bul1. Geol. Soc. Am., v. 71 , p. 219-222.

Hail, W.J., Jr., 1965, U.S. Geol. Survey unpub. reconn. map.

Hansen, W.R., and Peterman, Z.E., 1968, Basement-rock geochronology of the Black Canyon of the Gunnison, Colorado: U.S. Geol. Survey Prof. Paper 600-C, p. C80-C90.

Hedge, C.E., and others, 1968, Precambrian geochronology of the northwestern Uncompahgre Plateau, Utah and Colorado: U.S. Geol. Survey Prof. Paper 600-C, p. C-91-96.

Hem, J.D., 1970, Study and interpretation of the chemical characteristics of natural water: U.S. Geol. Survey Water-Supply Paper 1473, $363 \mathrm{p}$.

Iorns, W.V., Hembree, C.H., and Oakland, G.L., 1965, Water resources of the Colorado River Basin - Technical report: U.S. Geol. Survey Prof. Paper 441, 370 p.

Keller, G.V., 1977, Geophysical surveys at Pagosa Springs and Glenwood Springs: Unpub. report from Geophysics Fund, Inc., Colorado School of Mines.

Kelly, V.C., and Clinton, N.J., 1960, Fracture systems and tectonic elements of the Colorado Plateau: Univ. New Mexico Pub. Geology, no. $6,104 \mathrm{p}$. 
Koulet,-K.G., and Armstrong, J.A., 1978, An environmental report on the driliing and production testing of an exploratory geothermal weit in Pagosa Springs, Colorado: Report under contract by the Denver Research Institute, $69 \mathrm{p}$.

Kruseman, G.P., and de Ridder, N.A., 1970, Analysis and evaluation of pumping test data: Institute for Land Reclamation and Improvement, Wageningen, The Netherlands.

Lipman, P.W., Steven, T.A., and Mehnert, H.H., 1970, Volcanic history of the San Juan Mountains, Colorado, as indicated by potassium-argon dating: Geol. Soc. America Bul1., v. 81, no. 8, p. 2329-2352.

Lohman, S. W., 1972 , Ground-water hydraulics: U.S. Geological Survey Prof. Paper $708,70 \mathrm{p}$.

Pear1, R.H., 1972, unpublished groundwater report.

Peari, R.H., Galloway, M.J., and Dick, J., 1970, The Pagosa Springs Project--the first permitted geothermal wells in Colorado: Geothermal Resources Council, Transactions, v. 2, p. 517-519.

Read, C.B., Wood, G.H., Wanek, A.A., and Mackee, P.V., 1949, Stratigraphy and geologic structure in the Piedra River canyon, Archuleta County, Colorado: U.S. Geol. Survey $0 i 1$ and Gas Inv. Prelim. Map 96.

Ryder, R.T., 1977 a, $0 i 1$ and gas potential of the Chama-Southern San Juan Mountains wilderness study area, Mineral, Rio Grande, Archuleta, and Conejos Counties, Colorado, in Mineral resources of the Chama-Southern San Juan Mountain wilderness area, Mineral, Rio Grande, Archuleta, and Conejos Counties, Colorado: U.S. Geol. Survey open-file rept. 77-309, $210 \mathrm{p}$.

1977b, Hydrocarbon potential of the Archuleta anticlinorium, Brazos uplift, Chama basin: v. 77, no. 49, The $0 i 1$ and Gas Journal, Dec. 5, p. 163-170.

Steven, T.A., and others, 1974, Geologic map of the Durango quadrangle, southwestern Colorado: U.S. Geol. Survey Map I-764.

Vai1, E.E., 1896, Pagosa Hot Springs, the Carlsbad of America, Archuleta County, Colorado: Pagosa Springs Herald.

White, D.E., and Williams, D.L., eds., 1975, Assessment of geothermal resources of the United States - 1975: U.S. Geol. Survey Circ. $726,155 \mathrm{p}$.

Wood, G.H., and others, 1948, Geology of southern part of Archuieta County, Colorado: U.S. Geol. Survey $0 i 1$ and Gas Prel im. Map OM-81. 

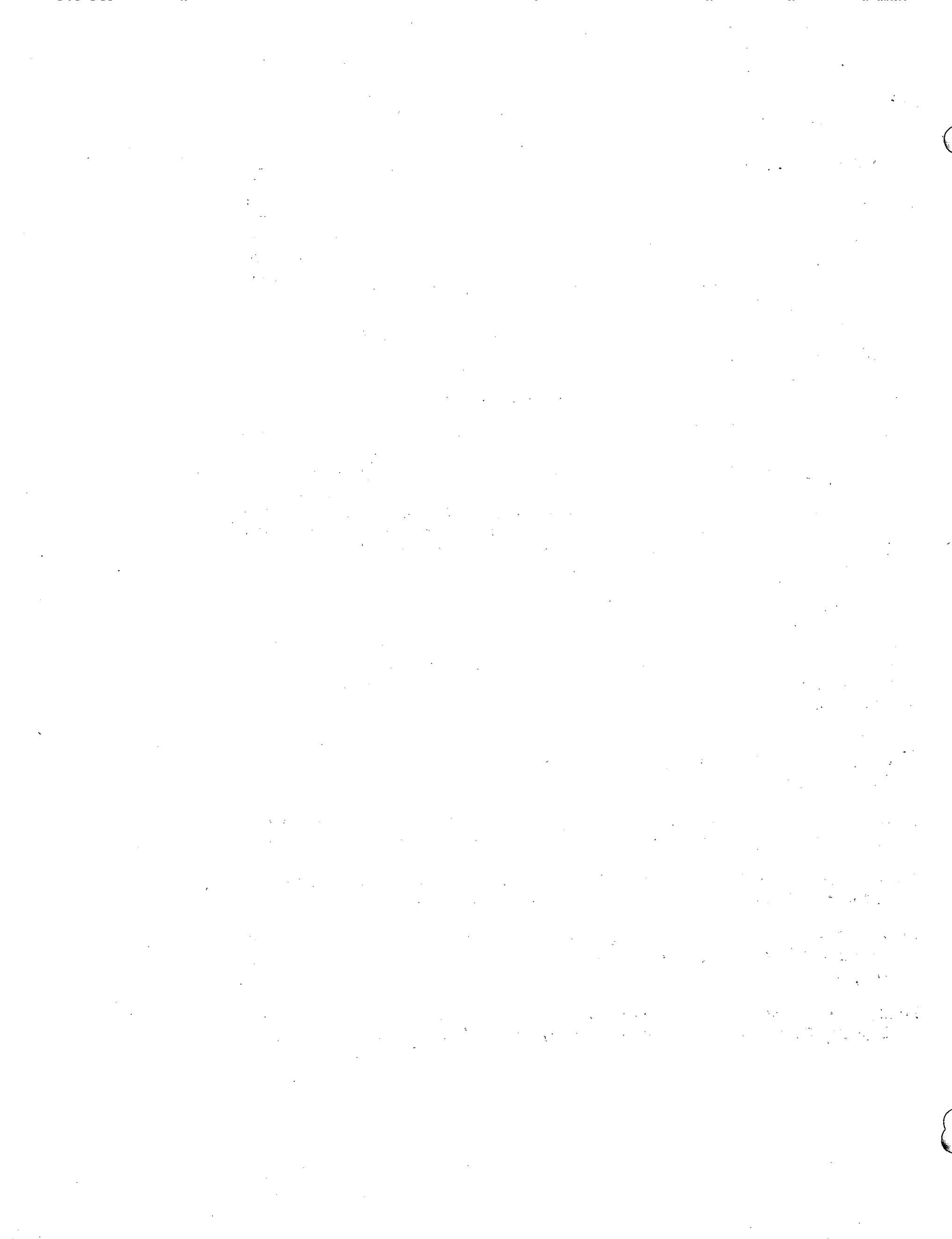

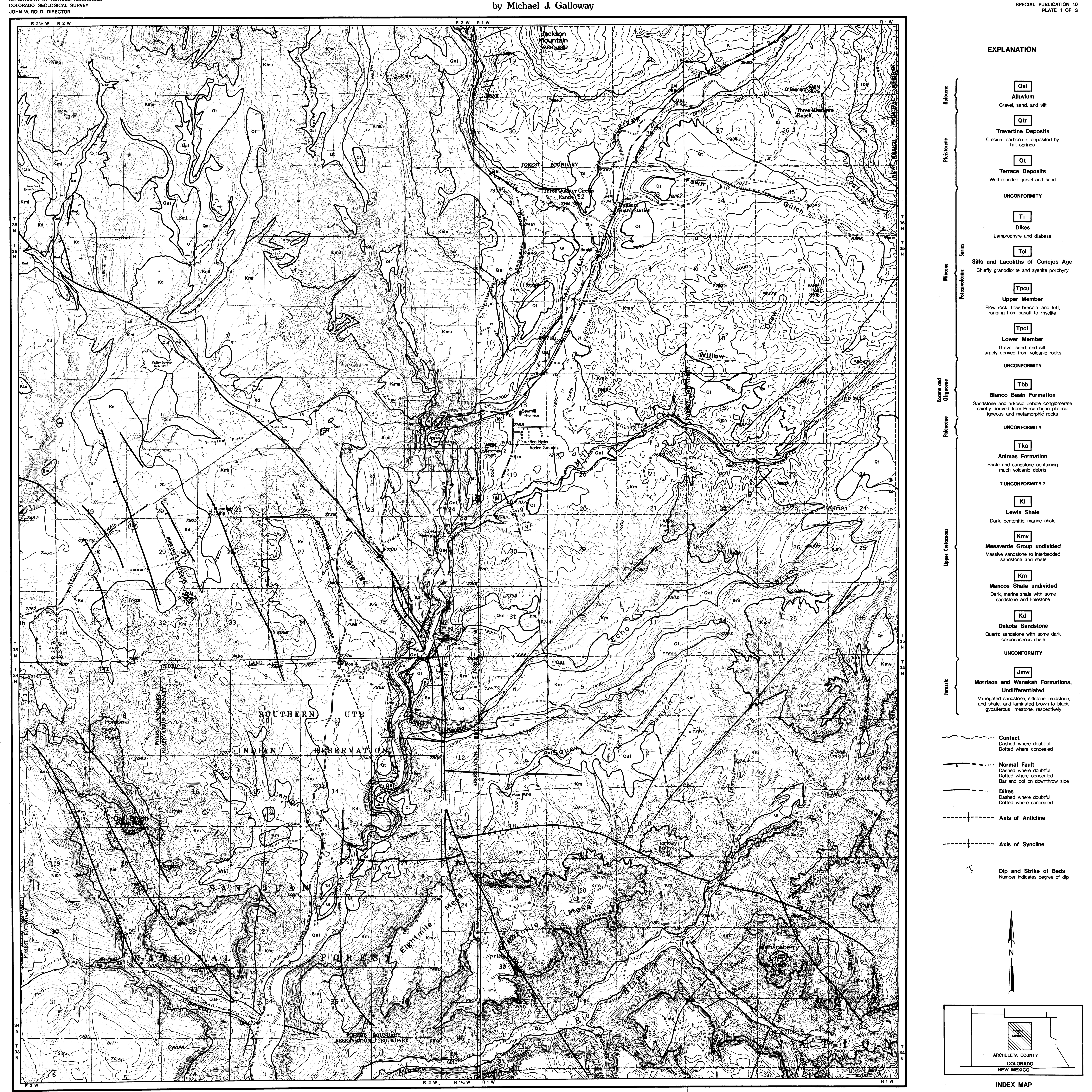


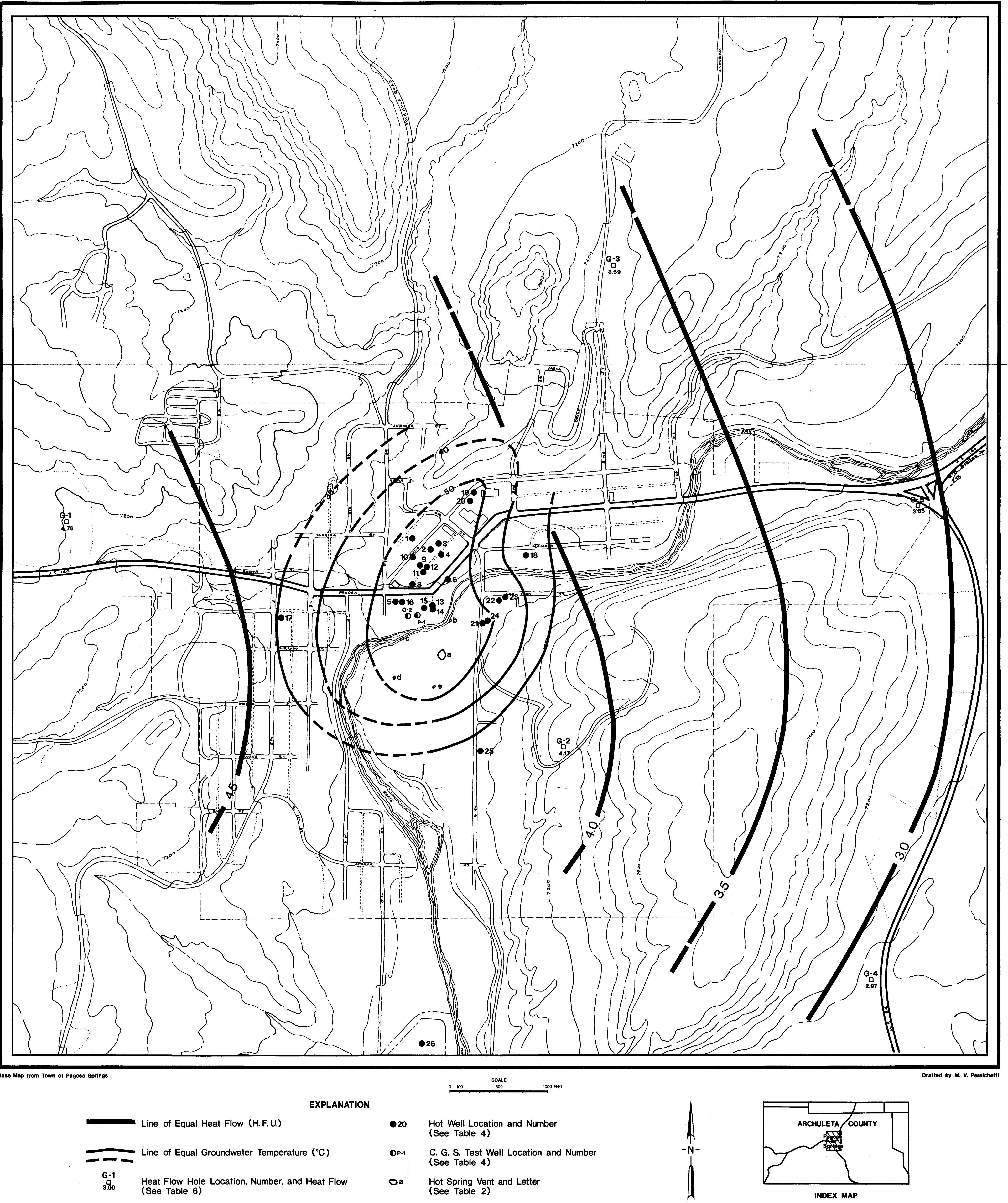




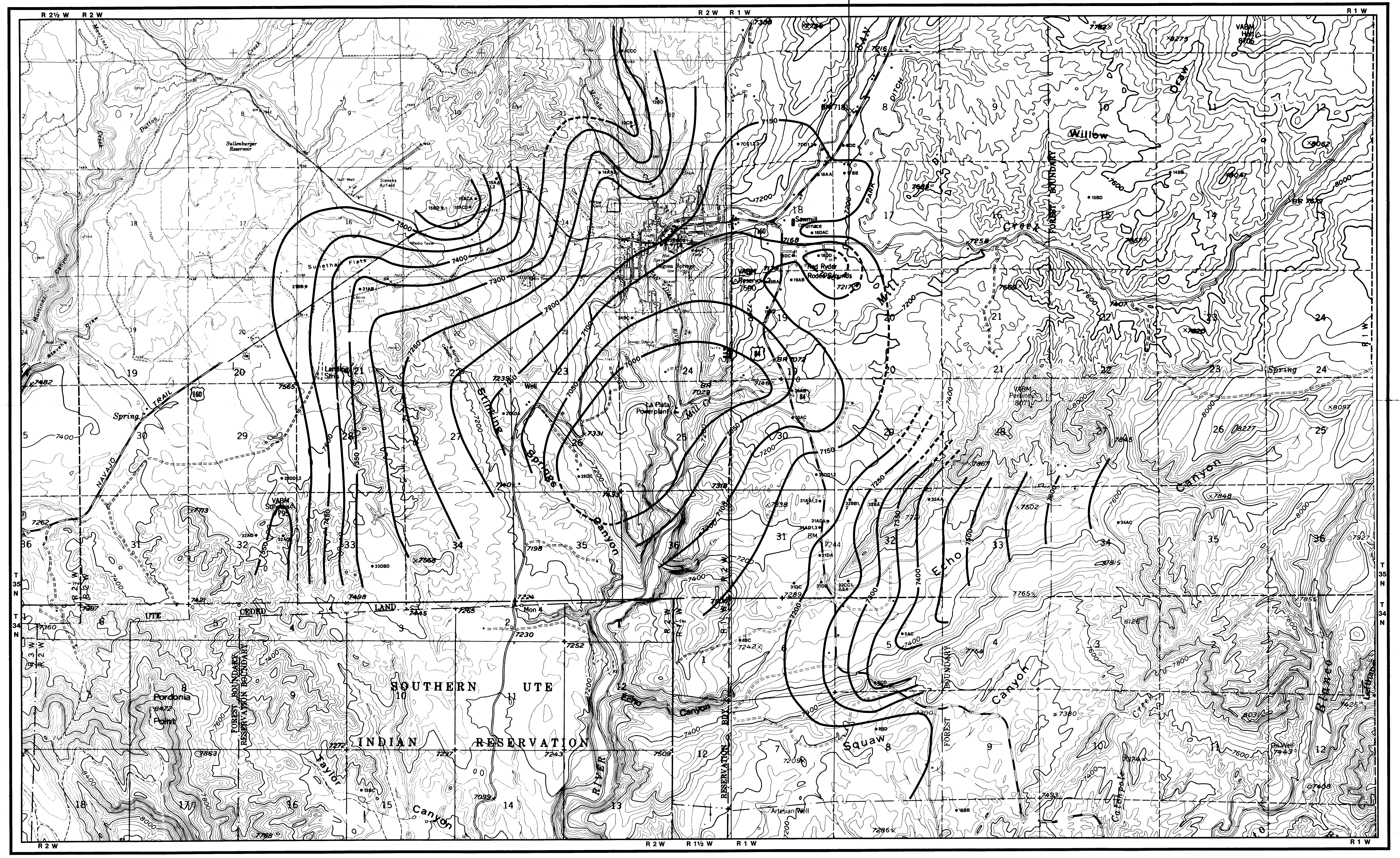

Figure 1 - Elevation of the Water Surface, Mancos Shale, Pagosa Springs Area, Colorado
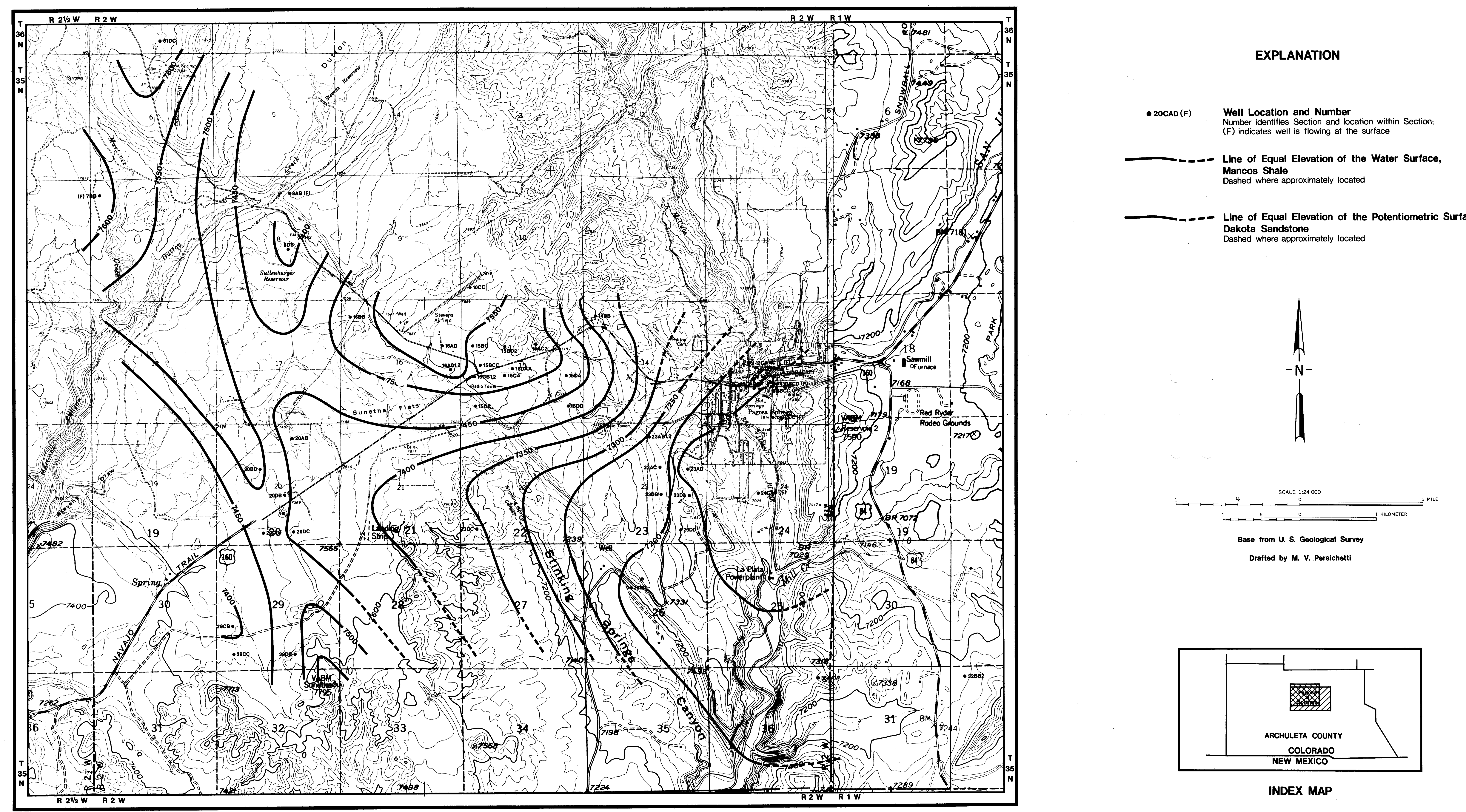

Figure 2 - Elevation of the Potentiometric Surface, Dakota Sandstone, Pagosa Springs Area, Colorado 